\title{
Task 15
}

\section{Thermal Depolymerization of Plastics -- PDU Testing}

\section{Topical Report}

January 1996

Work Performed Under Contract No.: DE-FC21-93MC30098

For

U.S. Department of Energy

Office of Fossil Energy

Morgantown Energy Technology Center

Morgantown, West Virginia

By

University of North Dakota

Energy \& Environmental Research Center

Grand Forks, North Dakota 


\section{NOTICE}

Page(s) size did not permit electronic reproduction. Information may be purchased by the general public from the National Technical Information Service, U.S. Department of Commerce, Springfield, VA 22161 (Area Code 703-487-4650). DOE and DOE contractors may purchase information by contacting DOE's Office of Scientific and Technical Information, P.O. Box 62, Oak Ridge, TN 37831, Attn: Information Services (Area Code 423-576-8401). 


\section{DISCLAIMER}

This report was prepared as an account of work sponsored by an agency of the United States Government. Neither the United States Government nor any agency thereof, nor any of their employees, makes any warranty, express or implied, or assumes any legal liability or responsibility for the accuracy, completeness, or usefulness of any information, apparatus, product, or process disclosed, or represents that its use would not infringe privately owned rights. Reference herein to any specific commercial product, process, or service by trade name, trademark, manufacturer, or otherwise does not necessarily constitute or imply its endorsement, recommendation, or favoring by the United States Government or any agency thereof. The views and opinions of authors expressed herein do not necessarily state or reflect those of the United States Government or any agency thereof.

This report has been reproduced directly from the best available copy.

Available to DOE and DOE contractors from the Office of Scientific and Technical Information, 175 Oak Ridge Turnpike, Oak Ridge, TN 37831; prices available at (615) 576-8401.

Available to the public from the National Technical Information Service, U.S. Department of Commerce, 5285 Port Royal Road, Springfield, VA 22161; phone orders accepted at (703) 487-4650. 


\title{
Task 15 \\ Thermal Depolymerization of Plastics -- PDU Testing
}

\author{
Topical Report
}

Work Performed Under Contract No.: DE-FC21-93MC30098

For

U.S. Department of Energy

Office of Fossil Energy

Morgantown Energy Technology Center

P.O. Box 880

Morgantown, West Virginia 26507-0880

By

University of North Dakota

Energy \& Environmental Research Center

P.O. Box 9018

Grand Forks, North Dakota 58202-9018

January 1996 


\section{ACKNOWLEDGMENTS}

This report covers work performed for the American Plastics Council (APC)-sponsored program, Process Development Test Program for the Thermal Recycling of Plastics. Testing occurred over the time period October 1993 to June 1994. Principal investigator for the project and primary author of this report was Laura L. Sharp. Project manager and contributing editor was Robert O. Ness, Jr. Contributing editor and analytical coordinator was Ted A. Aulich. The APC technical project monitor was Jose M. Sosa of Fina Oil and Chemical. We would like to thank the following EERC-and APC-affiliated persons for their contributions to the project:

\section{EERC}

Greg Anderson

Pete Behling

Wayne Blegen

Don Cox

John Haugen

Janelle Hoffarth

Ray Johnson

Tim Kujawa

Ron Kulas

Yufu Li

Carolyn Lillemoen

Janet Lucht

John Lutheran

Lorne McEwen

APC

John Forgac

Amoco Chemical Company

Naperville, Illinois

George Mackey

Dow Chemical Company

Granville, Ohio
Dave Miller

Bill Palmer

Mel Peterson

Jerry Petersburg

Debra Pflughoeft-Hassett

Hal Rugroden

Brian Runge

Art Rudd

Richard Shockey

Tom Stokke

Bill Sukalski

Jenny Sun

Jeff Thompson

Ron Timpe

\section{Roger Smith}

DuPont

Wilmington, DE 


\section{TABLE OF CONTENTS}

ACKNOWLEDGMENTS $\ldots \ldots \ldots \ldots \ldots \ldots \ldots \ldots \ldots \ldots \ldots \ldots$ iii

LIST OF FIGURES $\ldots \ldots \ldots \ldots \ldots \ldots \ldots \ldots \ldots \ldots \ldots \ldots \ldots \ldots$ viii

LIST OF TABLES $\ldots \ldots \ldots \ldots \ldots \ldots \ldots \ldots \ldots \ldots \ldots \ldots$ viii

EXECUTIVE SUMMARY $\ldots \ldots \ldots \ldots \ldots \ldots \ldots \ldots \ldots \ldots$ viiii

$1.0 \quad$ INTRODUCTION $\ldots \ldots \ldots \ldots \ldots \ldots \ldots \ldots \ldots \ldots \ldots \ldots \ldots$

2.0 TEST EQUIPMENT $\ldots \ldots \ldots \ldots \ldots \ldots \ldots \ldots \ldots \ldots \ldots \ldots \ldots \ldots$

3.0 FEED MATERIALS $\ldots \ldots \ldots \ldots \ldots \ldots \ldots \ldots \ldots \ldots \ldots \ldots \ldots$

4.0 EXPERIMENTAL CONSIDERATIONS $\ldots \ldots \ldots \ldots \ldots \ldots \ldots \ldots \ldots$

5.0 ANALYTICAL METHODS AND DATA REDUCTION $\ldots \ldots \ldots \ldots \ldots \ldots$

6.0 PDU RESULTS $\ldots \ldots \ldots \ldots \ldots \ldots \ldots \ldots \ldots \ldots \ldots \ldots \ldots \ldots$

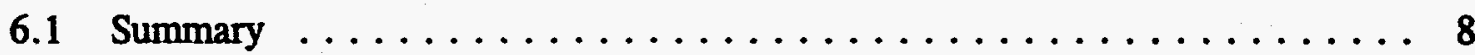

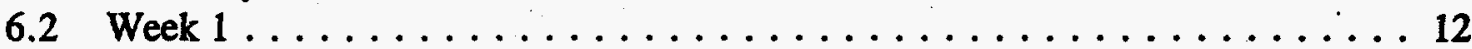

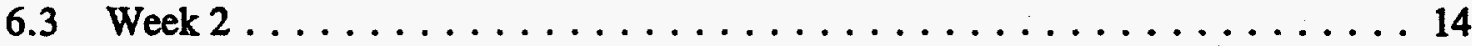

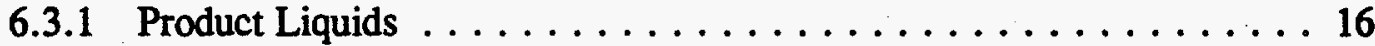

6.3.2 Chlorine Analyses $\ldots \ldots \ldots \ldots \ldots \ldots \ldots \ldots \ldots \ldots \ldots$

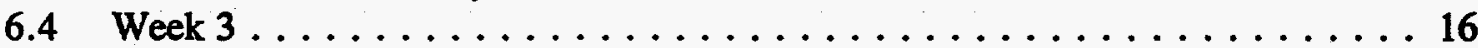

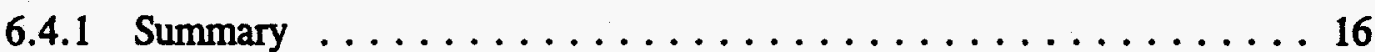

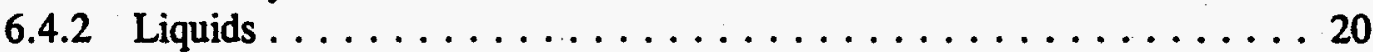

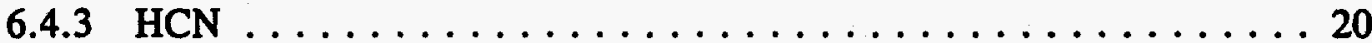

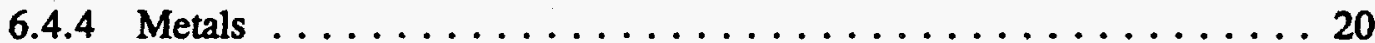

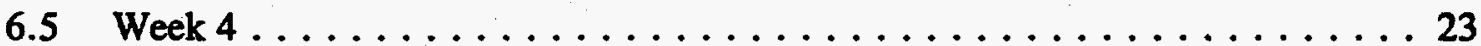

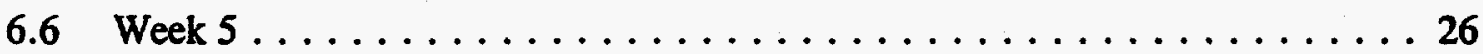

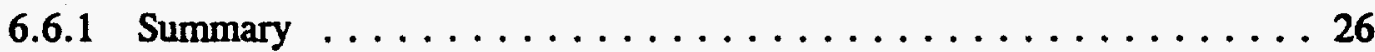

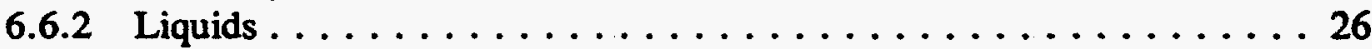

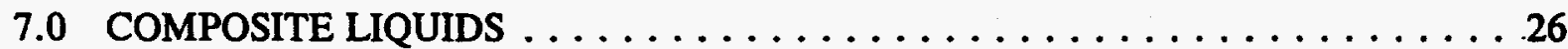

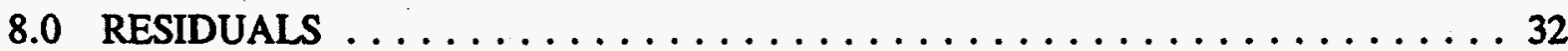

9.0 CFBR RESIDENCE TIME STUDY $\ldots \ldots \ldots \ldots \ldots \ldots \ldots \ldots \ldots \ldots \ldots \ldots \ldots$

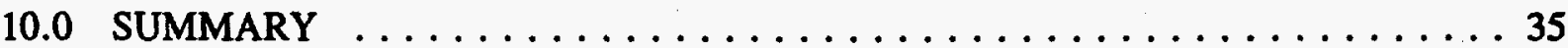

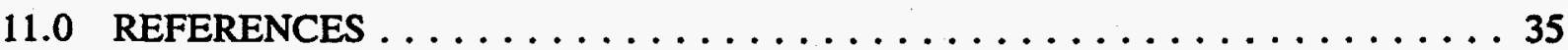


SOLVENT DISSOLUTION ANALYSIS METHOD ........... Appendix A ANALYTICAL PROCEDURES $\ldots \ldots \ldots \ldots \ldots \ldots \ldots \ldots \ldots$ Appendix B MATERIAL BALANCE SUMMARIES AND METHODS DESCRIPTION MATERIAL BALANCE CALCULATION METHODS $\ldots \ldots \ldots \ldots \ldots$ Appendix C

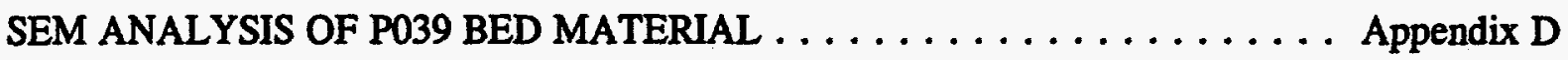
ANALYSIS OF P042 LIQUIDS $\ldots \ldots \ldots \ldots \ldots \ldots \ldots \ldots \ldots$ Appendix E TGA GRAPHS OF PDU SOLIDS $\ldots \ldots \ldots \ldots \ldots \ldots \ldots \ldots \ldots$ Appendix F 


\section{LIST OF FIGURES}

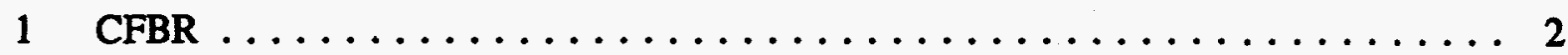

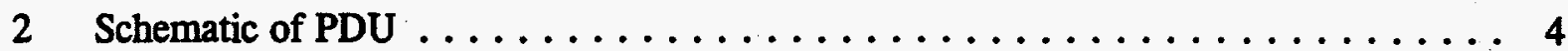

3 Simulated boiling point distribution $\ldots \ldots \ldots \ldots \ldots \ldots \ldots \ldots \ldots \ldots \ldots$

4 TGA profiles of three samples of P042 liquids recovered from sieve tower . . . . . 25

5 Simulated boiling point distribution and boiling point distribution minus xylene . . . 29

6 Simulated boiling point distribution for residence time series $\ldots \ldots \ldots \ldots \ldots 34$

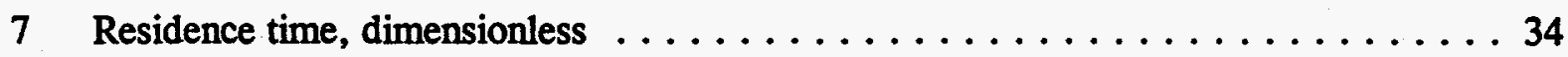

\section{LIST OF TABLES}

1 Rockport High-Calcium Lime $\ldots \ldots \ldots \ldots \ldots \ldots \ldots \ldots \ldots \ldots$

2 Summary of Test Conditions $\ldots \ldots \ldots \ldots \ldots \ldots \ldots \ldots \ldots$

3 Analytical Methods $\ldots \ldots \ldots \ldots \ldots \ldots \ldots \ldots \ldots \ldots \ldots \ldots$

4 Operational Summary of PDU Tests $\ldots \ldots \ldots \ldots \ldots \ldots \ldots \ldots$

5 Chlorine Analysis and Balance for $\mathrm{P} 039 \ldots \ldots \ldots \ldots \ldots \ldots \ldots \ldots$

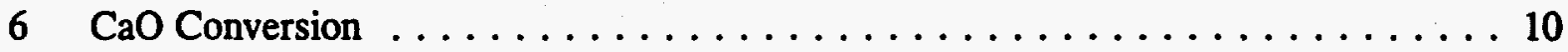

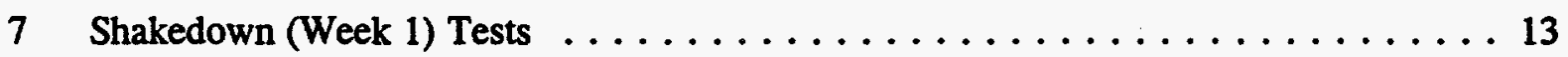

8 Tabular Listings of Product Liquid Components . . . . . . . . . . . . . 14

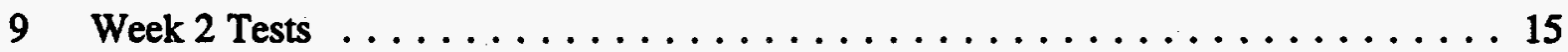

10 Proximate Analyses for P039 Bed Material Samples $\ldots \ldots \ldots \ldots \ldots \ldots$

11 Component Analyses for $\mathrm{P} 038-\mathrm{P} 039 \ldots \ldots \ldots \ldots \ldots \ldots \ldots \ldots$

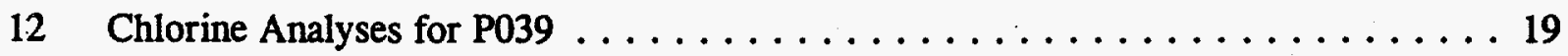


13 Week 3 Tests $\ldots \ldots \ldots \ldots \ldots \ldots \ldots \ldots \ldots \ldots \ldots \ldots \ldots \ldots$

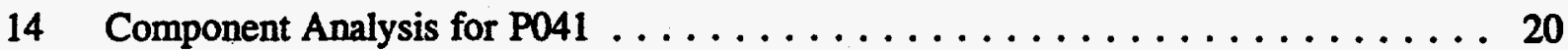

$15 \quad$ P041 Metals and $\mathrm{Cl}$ Analyses $\ldots \ldots \ldots \ldots \ldots \ldots \ldots \ldots \ldots \ldots \ldots \ldots$

16 Week 4 Tests $\ldots \ldots \ldots \ldots \ldots \ldots \ldots \ldots \ldots \ldots \ldots \ldots \ldots \ldots \ldots \ldots$

17 P042 Sieve Tower Proximate Analyses $\ldots \ldots \ldots \ldots \ldots \ldots \ldots \ldots \ldots$

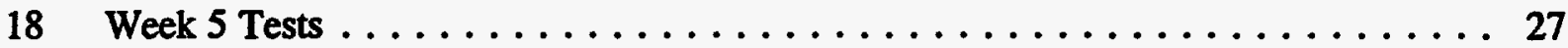

19 Product Liquid Analysis for $\mathrm{P} 044 \ldots \ldots \ldots \ldots \ldots \ldots \ldots \ldots \ldots \ldots \ldots$

20 Properties of Plastics Decomposition Liquids Composite Sample . . . . . . . . 29

21 Analysis of Big Reactor Composite Depolymerization Liquids . . . . . . . . . 30

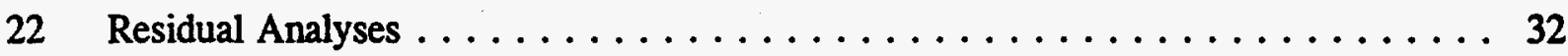

23 Residence Time Study Results $\ldots \ldots \ldots \ldots \ldots \ldots \ldots \ldots \ldots \ldots \ldots$

24 Residence Time Study Component Analysis $\ldots \ldots \ldots \ldots \ldots \ldots \ldots \ldots \ldots$ 


\section{THERMAL DEPOLYMERIZATION OF PLASTICS PDU TESTING}

\section{EXECUTIVE SUMMARY}

The process development unit (PDU) test program is part of an ongoing effort at the Energy \& Environmental Research Center (EERC) to expand the base of knowledge for the thermal depolymerization of plastics process. This phase of the development effort, initiated after successful completion of a bench-scale program, has concentrated on maximizing liquid yield. The purposes of the PDU program were 1) to demonstrate the process on a commercially scalable unit, 2) to produce quantities of product that could be used to initiate discussions with potential end users, and 3) to gather engineering and yield data.

Experimentation consisted of eleven test points on the PDU and seven on the continuous fluid-bed reactor (CFBR) bench-scale unit. Initial PDU tests (P035-P039) were carried out using a base blend, which consists of $60 \%$ high-density polyethylene (HDPE), $20 \%$ polypropylene (PP), and $20 \%$ polystyrene (PS) virgin resin pellets. Test P039 used base blend with $5 \%$ polyvinyl chloride (PVC). The base blend decomposed to produce a flowable liquid, with liquid yields ranging from $33 \%$ to $45 \%$. The next series of tests, P040-P044, used a postconsumer plastics feed. This material did not decompose as readily as the base blend and formed a very waxy, heavy liquid, with "liquid" yields ranging from $18 \%$ to $63 \%$ (low liquid yields are the result of using excess air in the natural gas burner in some tests in an attempt to increase gas residence time). After several marginally successful attempts at producing a lighter liquid, a decision was made to discontinue PDU testing until a better understanding of the conditions necessary to produce a satisfactory liquid was attained. Possible explanations considered for the heaviness of the liquids made from postconsumer material included 1) insufficient gas residence time, 2) $\mathrm{CaO}$ fines carryover and suspension in product liquids, 3) the presence of quantities of nonplastic substances on the postconsumer material influencing decomposition, 4) formation of calcium terephthalate or other organic acid-calcium compounds from polyethylene terephthalate (PET) decomposition, or 5) coking of PET. Analysis of the liquids and solid residuals from the tests indicated that insufficient gas residence time was the cause of the heavier-than-expected liquid product. To verify this and to find a range of acceptable gas residence times, a series of tests was run on the bench-scale CFBR unit. Of secondary concern were whether or not steam was an important variable and the effect of $\mathrm{CaO}$ concentration. Most work prior to the PDU program was performed without steam. Earlier work was done on the CFBR, which has indirect heaters. The PDU, on the other hand, relies on a natural gas-fired burner for process heat. A byproduct of the natural gas burner is water. Two levels of $\mathrm{CaO}$ (5\% and $15 \%$ ) were tested in the CFBR to examine $\mathrm{CaO}$ concentration effect. A significant gas residence effect was observed, both on gas and liquid quality.

Based on the bench-scale studies, the gas residence time required to produce liquids of suitable quality from postconsumer plastics at $625^{\circ} \mathrm{C}$ was found to be approximately . 23 seconds. PDU tests reported here were carried out at gas residence times of between 14 and 19 seconds. (The 19-second test employed excess air in the burner to burn some of the feed for process heat and, therefore, has a low liquid yield.) Note that the required residence time is 
dependent on decomposition temperature and feed material. In order to allow for future PDU operation over the desired range of gas residence times, the bottom two sections of the PDU were increased from 8-in. inner diameter (ID) to 10 -in. ID by removing 2 in. of the refractory.

Additionally, the pneumatic transport system was replaced with a dual auger arrangement, similar to that of the CFBR.

A pair of fluid-bed consultants was retained to evaluate the PDU program. Their suggestions were incorporated into the test plans laid out at the start of the program. A short report issued by these consultants is attached as an appendix. 


\section{THERMAL DEPOLYMERIZATION OF PLASTICS PDU TESTING}

\subsection{INTRODUCTION}

Presently, some types of plastics (mainly polyethylene terephthalate [PET] and highdensity polyethylene [HDPE]) are collected and recycled to plastics of that same type by chemical or mechanical methods. These methods of recycling require relatively clean, homogeneous streams. Processes to recycle PET or HDPE exist mainly because large enough quantities of feed are available at a sufficiently low price to make the process economic. For many types of plastics, delivery of sufficient quantities (collection, sortation, preparation, and transportation) to a process dedicated solely to the recycling of that plastic is presently economically prohibitive. In order to recycle large quantities of postconsumer plastics, processes that are able to accept mixed streams are necessary. Methods to form usable products with minimal processing of postconsumer plastics also exist, such as plastic lumber and trash bag manufacturing, but have limited markets when compared to the abundance of plastic available for recycling. Traditional recycling processes such as these are an important part of the overall recycling effort but cannot process all types of plastics streams and do not accept sufficient quantities of material to achieve the higher recycling level desired for plastics. As an additional recycling option, several groups around this country and in Europe are examining methods of thermal decomposition (sometimes referred to as thermal depolymerization, chemical recycling, tertiary recycling, or feedstock recycling) of mixedplastic streams. A range of hydrocarbon liquid and gaseous products are available from this type of process, many of which have potentially large markets. The products of thermal depolymerization can be used for the manufacture of new plastics or of various other hydrocarbon-based products. Recycling mixed-plastic streams presents many challenges. Postconsumer plastics streams are highly heterogeneous. Because of the many applications of plastics, numerous additives, both inorganic and organic, are present. Contaminants from use by the consumer will be mixed with the plastics (e.g., paint, paint thinner, food, metals, paper, adhesives). Processes to recycle postconsumer plastics will need to account for all of these factors.

Thermal depolymerization process development began at the Energy \& Environmental Research Center (EERC) with a bench-scale program that ran from September 1992 to June 1993 (1). Testing conducted in a 1-4-lb/hr continuous fluid-bed reactor (CFBR) unit using individual virgin resins and resin blends was intended to determine rough operating parameters and product yields and to identify product stream components. Process variables examined included temperature and bed material, with a lesser emphasis on gas fluidization velocity and feed material mix. Following successful completion of the study using virgin resins, postconsumer plastics were tested. Next, a short program was completed that examined the use of $\mathrm{CaO}$ in a postreactor fixed bed for chlorine removal.

The follow-up to the bench-scale projects, described here, covers testing on a $100-\mathrm{lb} / \mathrm{hr}$ process development unit (PDU). Several bench-scale tests performed as new questions arose 
from the PDU program will also be covered. The purposes of the PDU program are to 1) prove the concept on a commercially scalable unit, 2) identify engineering challenges, 3) gather engineering and yield data for scaleup, and 4) generate quantities of products for qualification and evaluation by end users.

While the overall objective of efforts at the EERC is to quantitatively and qualitatively determine the potential slate of products from the thermal depolymerization of plastics as a function of process variables, this phase of the PDU program has focused on maximizing the yield of hydrocarbon liquid product.

\subsection{TEST EQUIPMENT}

Experiments described here were performed in both the $100-\mathrm{lb} / \mathrm{hr}$ PDU and the 1-4-lb/hr CFBR. The CFBR (Figure 1) consists of a 1-4-1b/hr fluid-bed reactor, gas conditioning train, solids feed system, and condensation train. The reactor is rated to $825^{\circ} \mathrm{C}$ and $175 \mathrm{psi}$ and is indirectly heated. The bottom section is 33 in. long and has a nominal 3-in. ID. The top section is 17.5 in. long and has a 4-in. ID. The primary means of solids removal is a top bed drain leg, located at the junction of the 3-4-in. sections. Solids are introduced through a bottom, side port via a dual auger system. The top, horizontal auger meters feed material from the feed hopper. The metered feed material gravity drops to a second auger, which is at $60^{\circ}$ from horizontal. The angled auger runs very fast and delivers the feed material quickly into the bottom of the reactor before melting can occur. The condensation train consists of a series of

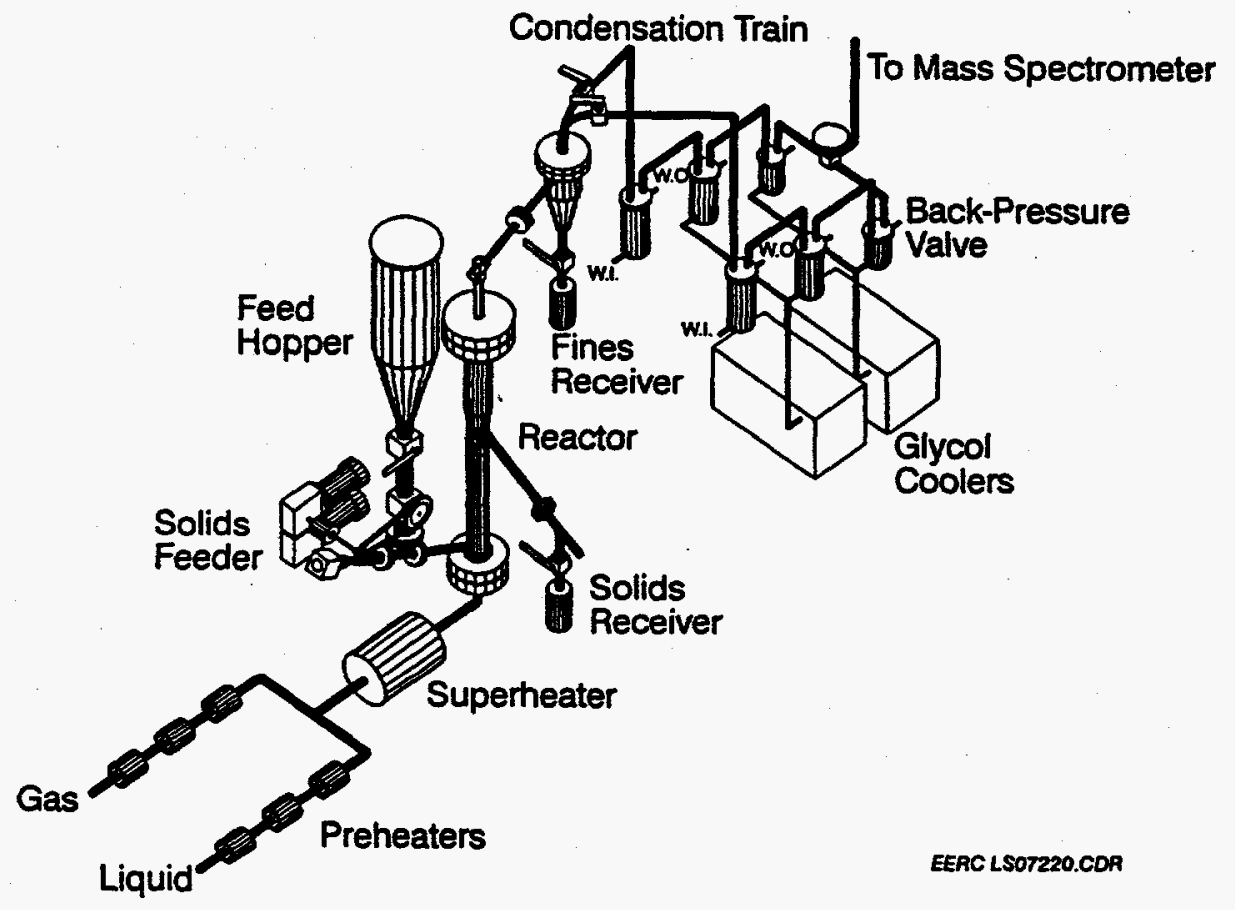

Figure 1. CFBR. 


\section{Thermal Depolymerization of Plastics}

three indirectly cooled condensation pots. The first of these pots is water-cooled, and the second and third are glycol-cooled.

The PDU fluid-bed reactor, solids feed system, gas conditioning system, and condensation train are shown in Figure 2. The fluid-bed reactor consists of four 5-foot-long refractory-lined sections. The first two sections have 8-in. IDs, and the second two have 16-in. IDs. Feed is introduced to the system either through the bottom center of the reactor, using a pneumatic transport line, or through a bottom, side port, also using the pneumatic transport system. The condensation train of the PDU consists of a sieve tower, followed by a series of two water venturi scrubbers. Both the sieve tower and the venturis use condensed product liquids as cooling fluids. Gas is analyzed by gas chromatography (GC) grab bag samples and by on-line analyzers for both the PDU and CFBR.

\subsection{FEED MATERIALS}

Three feed material mixes were used in the tests described here. "Base blend" refers to a mix of virgin resin pellets composed of $60 \%$ HDPE, $20 \%$ polystyrene (PS), and $20 \%$ polypropylene (PP). Two postconsumer blends were tested. Both blends were procured from Quality Checked of Paynesville, Minnesota. The first postconsumer blend consisted mainly of HDPE, with small amounts of PP and PS present, based on historical assay provided by Quality Checked. The second blend consisted of approximately $59.2 \%$ HDPE, $20.1 \%$ PET, $0.6 \%$ polyvinyl chloride (PVC), 10.7\% PP, 4.7\% PS, and 4.7\% low-density polyethylene (LDPE). This analysis was provided by Southwest Research Corporation of San Antonio. A description of the method used is found in Appendix H. It should be noted that the postconsumer material is highly heterogeneous and that only one sample was analyzed. While some care was taken to submit a representative sample, no accuracy for the analytical method has been established. Bed materials used were sand and $\mathrm{CaO}$. The sand was $20 \times 40$ mesh. $\mathrm{CaO}$ was procured from Cutler-Magner of Duluth, Minnesota, and was sized to $-1 / 4$ in. An analysis for the $\mathrm{CaO}$ is given in Table 1.

\section{TABLE 1}

Rockport High-Calcium Lime (typical analysis) ${ }^{2}$

\begin{tabular}{lcc}
\hline Calcium Oxide (total) & $\mathrm{CaO}$ & $95.00 \%$ \\
Calcium Oxide (available) & $\mathrm{CaO}$ & $92.00 \%$ \\
Magnesium Oxide & $\mathrm{MgO}$ & $1.20 \%$ \\
Silica & $\mathrm{SiO}_{2}$ & $0.95 \%$ \\
Iron Oxide & $\mathrm{Fe}_{2} \mathrm{O}_{3}$ & $0.34 \%$ \\
Aluminum Oxide & $\mathrm{Al}_{2} \mathrm{O}_{3}$ & $0.20 \%$ \\
Sulfur & $\mathrm{S}$ & $0.05 \%$ \\
Phosphorus Pentoxide & $\mathrm{P}_{2} \mathrm{O}_{5}$ & $0.02 \%$ \\
Manganese & $\mathrm{Mn}$ & $0.02 \%$ \\
Titanium Oxide & $\mathrm{TiO}_{2}$ & $0.02 \%$ \\
LOI & & $1.51 \%$ \\
\hline
\end{tabular}

From Cutler-Magner Company, Duluth, MN.

${ }^{b}$ Loss on ignition. 


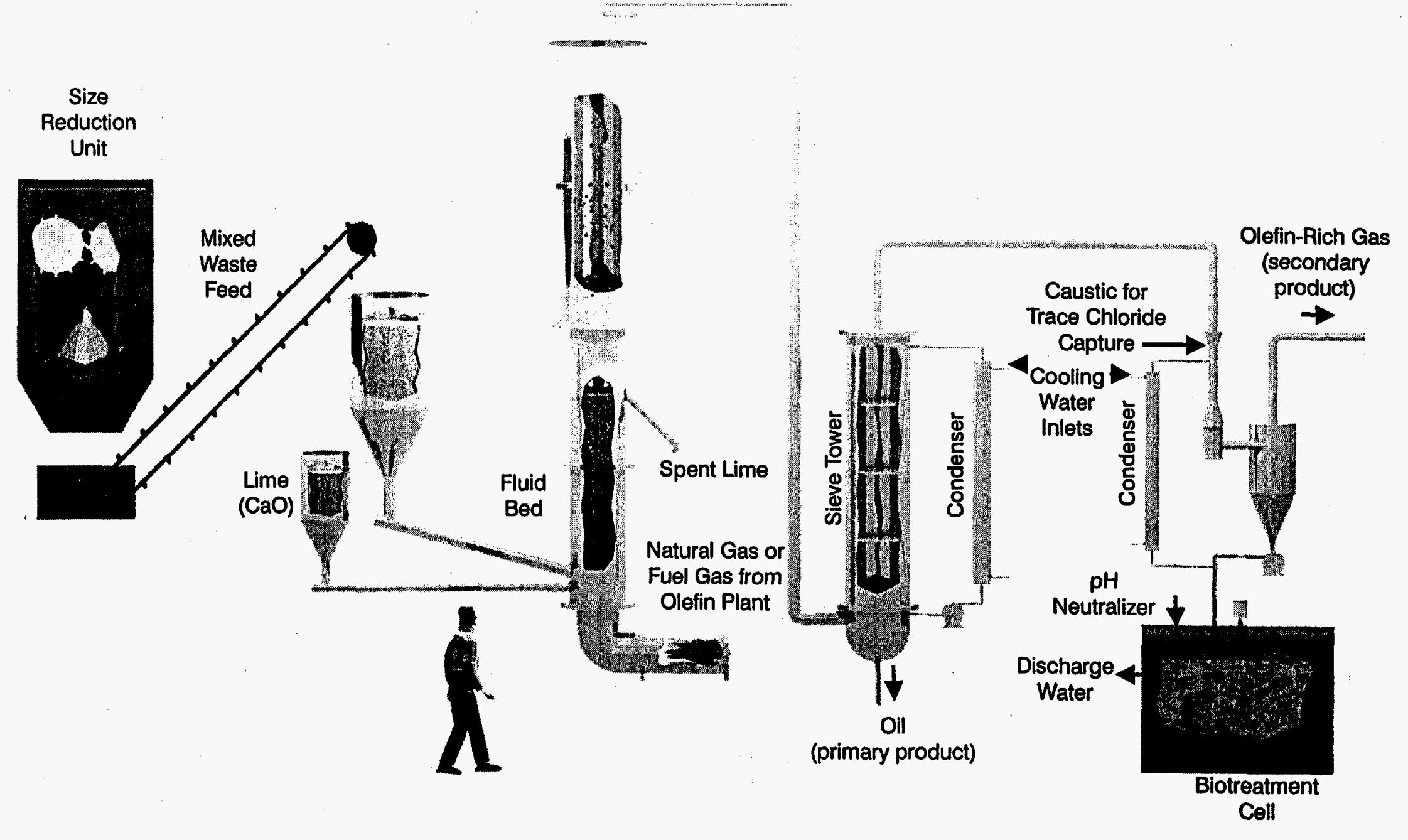

Figure 2. Schematic of PDU. 


\section{Thermal Depolymerization of Plastics}

\subsection{EXPERIMENTAL CONSIDERATIONS}

Experiments on the PDU consisted of 11 test conditions, as shown in Table 2. The first few tests in the series were intended to begin with the easiest process conditions, and with complicating factors gradually added in subsequent tests. Conditions or factors seen as potentially difficult were $\mathrm{CaO}$ as a bed material, PVC in the feed, high PET postconsumer plastics, and low decomposition temperatures. Feed introduction was also considered as a potential difficulty.

$\mathrm{CaO}$ is used for chlorine capture when PVC or other chlorine-containing plastics are present. One difficulty anticipated with $\mathrm{CaO}$ was attrition in the bed, due to the higher fluidization velocities of the PDU relative to the CFBR (where data used for design of PDU tests originated). The PDU does have two cyclones for fines removal, but since little information was yet available on the degree of attrition, the adequacy of these cyclones was unknown. Attrition is a concern, because $\mathrm{CaO}$ fines in the product liquids are difficult to remove and add $a$ unit operation (cost) to the process.

While $\mathrm{CaO}$ was shown to be quite efficient in chlorine removal in the bench-scale tests, the PDU has a much higher partial pressure of $\mathrm{CO}_{2}$ than the CFBR. The CFBR is indirectly heated, while the PDU relies on a direct-fired natural gas burner for process heat. $\mathrm{CO}_{2}$ from the burner may react with $\mathrm{CaO}$ to form $\mathrm{CaCO}_{3} \cdot \mathrm{CaCO}_{3}$ has been shown to be ineffective for chlorine capture (1).

Postconsumer plastics containing high levels of PET ( $>10 \%)$ had been observed to cause processing difficulties (1). This is especially true when PET is decomposed without adequate steam/PET ratios (2). Because of limits on quench train cooling capacity, only approximately $30 \mathrm{lb} / \mathrm{hr}$ steam could be fed.

Low-temperature tests will result in waxy liquids. The PDU, originally designed for a coal pyrolysis project, was modified (condensation and feed systems) for processing plastics. Prior to the first test with plastics, these modifications had yet to be tested.

Several problems were possible with feeding postconsumer plastic. At the suggestion of fluid-bed scaleup consultants, the point of feed introduction to the process was changed so that material entered through the center of the bed. The change to center feed introduction occurred prior to testing with postconsumer plastics. Feeding to the bottom, center of the bed enables a less complicated model of the system (for scaleup considerations) to be constructed. Center feed implies pneumatic transport in the existing reactor configuration. The plastic, sized to $-1 / 4$ in., is difficult to move, having no angle of repose. An additional constraint is imposed by the need to keep the transport tube as small as possible, so as to minimize the amount of cold transport gas added to the system.

\subsection{ANALYTICAL METHODS AND DATA REDUCTION}

Table 3 lists analytical methods used to qualify various products. Standard methods are noted as such. Nonstandard methods and variations on standard methods are detailed in Appendix B. 
TABLE 2

Summary of Test Conditions

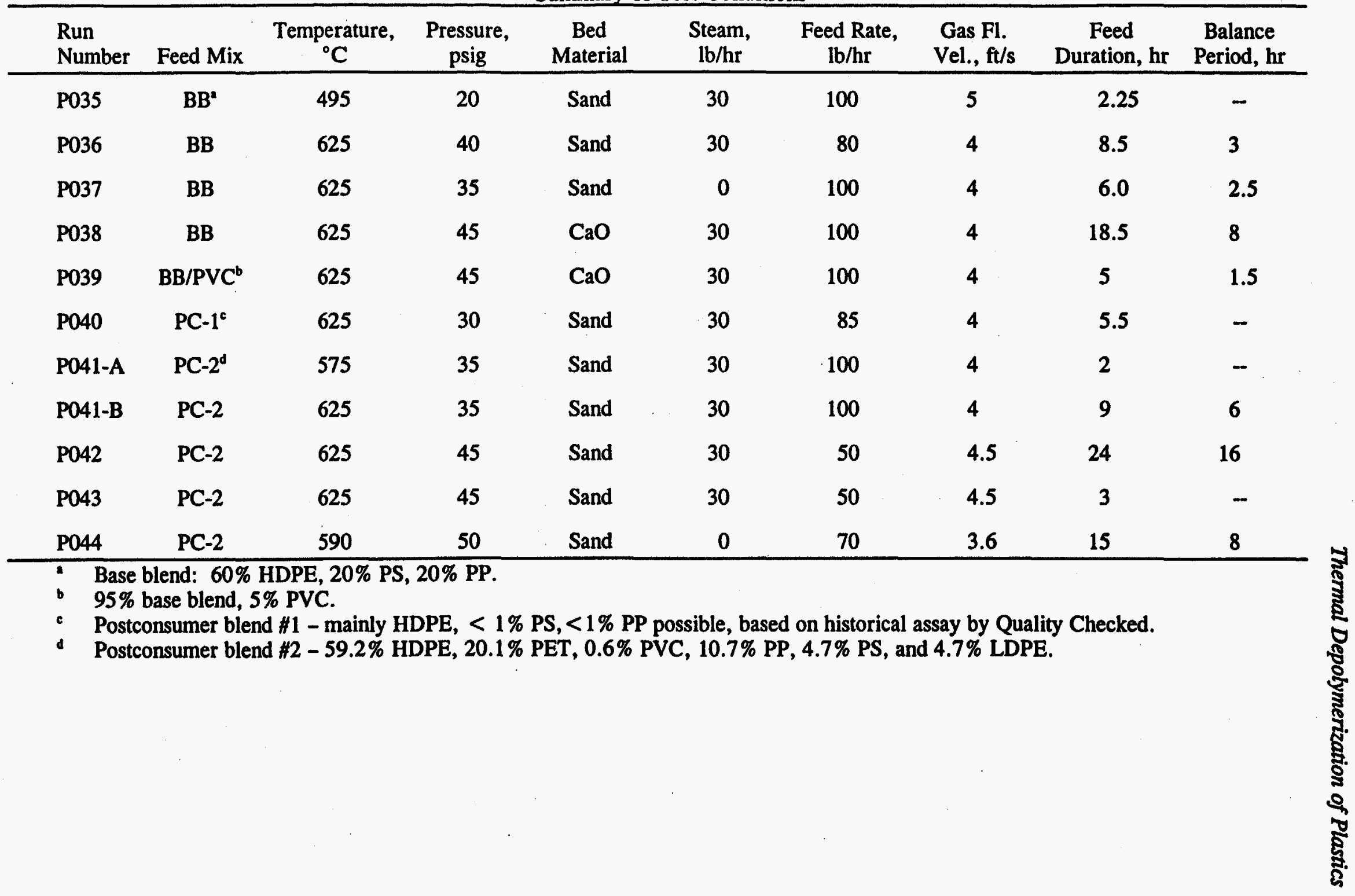


TABLE 3

Analytical Methods

\begin{tabular}{|c|c|c|}
\hline Sample Description & Measurement & Method \\
\hline Plastic Feedstock & $\begin{array}{l}\mathrm{V}, \mathrm{Ni}, \mathrm{Fe}, \mathrm{Cu} \\
\mathrm{Cl}\end{array}$ & $\begin{array}{l}\text { EPA Method } 3051,6010 \\
\text { ASTM D808-91 }\end{array}$ \\
\hline Product Gas & $\begin{array}{l}\text { Moisture, fixed carbon, volatiles, ash } \\
\mathrm{H}_{2}, \mathrm{CO}_{2}, \mathrm{CO}, \mathrm{CH}_{4}, \mathrm{~N}_{2}, \mathrm{C}_{3} \mathrm{H}_{6}, \mathrm{C}_{3} \mathrm{H}_{8} \text {, } \\
\text { I-butane, n-butane, 1-butene, t-2-butene, } \\
\text { I-pentane, c-2-butene, n-pentane, } \mathrm{C}_{2} \mathrm{H}_{4} \text {, } \\
\mathrm{C}_{2} \mathrm{H}_{6}, \mathrm{O}_{2}\end{array}$ & $\begin{array}{l}\text { ASTM D3172-89' } \\
\text { GC (Appendix B) }\end{array}$ \\
\hline Organic Liquids & $\begin{array}{l}\text { Boiling point distribution } \\
\text { Component analysis } \\
\text { Total chlorine } \\
\text { Organic chlorine } \\
\text { Terephthalic acid } \\
\mathrm{V}, \mathrm{Ni}, \mathrm{Fe}, \mathrm{Cu} \\
\mathrm{Cl} \\
\text { Cyanide }\end{array}$ & $\begin{array}{l}\text { GC-FID }{ }^{b} \text { (Appendix B) } \\
\text { GC-MS } \\
\text { ASTM D808-91 } \\
\text { GC-AED (Appendix B) } \\
\text { See Appendix B } \\
\text { EPA Method 3051, } 6010 \\
\text { ASTM D808-91 } \\
\text { Standard Method } 4500 \\
\text { American Public Health } \\
\text { Association }\end{array}$ \\
\hline Water & Chlorine & $\begin{array}{l}\text { Standard Method } 4500 \\
\text { American Public Health } \\
\text { Association } \\
\text { EPA Method } 3000\end{array}$ \\
\hline $\begin{array}{l}\text { Solids (spent bed } \\
\text { material }+ \text { ash) }\end{array}$ & $\begin{array}{l}\text { Moisture, fixed carbon, volatile, and ash } \\
\text { content } \\
\mathrm{V}, \mathrm{Ni}, \mathrm{Fe}, \mathrm{Cu} \\
\mathrm{Cl} \\
\text { Total chlorine }\end{array}$ & $\begin{array}{l}\text { ASTM D3172-89" } \\
\text { EPA Method } 3051,6010 \\
\text { ASTM D808-91 } \\
\text { Bomb digestion followed } \\
\text { by ion chromatography }\end{array}$ \\
\hline \multicolumn{3}{|c|}{$\begin{array}{l}\text { The thermogravimetric analysis (TGA) proximate analysis used is slightly different from the } \\
\text { ASTM specification. In the TGA method, when the sample is heated to } 110^{\circ} \mathrm{C} \text { for the } \\
\text { moisture analysis determination, the sample is held at } 110^{\circ} \mathrm{C} \text { until weight loss ends, whereas } \\
\text { the ASTM method specifies a } 1 \text {-hour hold time. This is justified since the sample size used in } \\
\text { the TGA method is small ( }<100 \mathrm{mg} \text { ) compared to that used for non-TGA tests (1000 mg). } \\
\text { bas chromatography-flame ionization detection. } \\
\text { Gas chromatography-mass spectrometry. } \\
\text { Modified slightly to allow chlorine quantification using ion chromatography instead of silver } \\
\text { chloride precipitation. }\end{array}$} \\
\hline
\end{tabular}


Appendix $\mathrm{C}$ details the material balance procedure used. Material balance sheets for all applicable tests are given in Appendix $\mathrm{C}$ also. Water and gas yields are combined, as the natural gas burner produces both gas and water, and measurements of gases entering the process are made prior to the burner. Ratios of air to $\mathrm{CH}_{4}$ varied, but are indicated for each test.

\subsection{PDU RESULTS}

\subsection{Summary}

Table 4 summarizes all completed tests and conditions, and summarizes key operational notes on the performance of the system. Feeding plastics to the system through the pneumatic transport tube was initially troublesome. Several times, plastic melted in the tube, blocking flow. Another problem encountered was long pieces of plastic bridging across the tube diameter. Although the plastics had been classified to $-1 / 4$ in., some longer slivers of plastic passed through the screens. This problem could be minimized by several passes through a classifier, but this additional feed preparation adds cost and does not wholly ensure the elimination of oversized pieces. Loss of feed to such an endothermic process results in significant system upset. When feed is lost, temperature rapidly increases in the reactor. While process controls are in place to prevent temperature runaway, the increase that results during the response time is unacceptable. At around $850^{\circ} \mathrm{C}$, the plastics in the bed will experience severe coking. After several attempts at modification to the pneumatic transport configuration (P037-P044), the feed system was modified so that an auger was used to deliver the feed material into the bottom side of the reactor (Figure 2), similar to the feed system of the benchscale unit.

Chlorine concentration of the various streams from Runs P039 and P041 are given in Table 5. Chlorine balances are unavailable for these tests, but as Table 5 shows, chlorine concentration for liquids from P039 is $<0.1$ ppm and for P041, $430 \mathrm{ppm}$.

The change in volatile content of the bed material, as measured by TGA proximate analysis, gives a measure of conversion of $\mathrm{CaO}$ to $\mathrm{CaCO}_{3}$ (Table 6). Volatile content for the starting and ending bed material samples for both of these tests is lost after $800^{\circ} \mathrm{C}$, indicating $\mathrm{CO}_{2}$ evolution. Therefore this can be used as a measure of $\mathrm{CO}_{2}$ absorption. While no conclusions can be made as to why chlorine content of the P039 product liquids is lower than the P041 product liquid chlorine content (numerous differences exist between the two tests, including different feed compositions, points of feed introduction, starting bed material, and temperature), it can be observed that more of the bed material from $\mathrm{PO41}$ is $\mathrm{CaCO}_{3}$, compared with the bed material from P039.

Although PET was present in the postconsumer plastics, difficulties in processing this feed material did not appear to result from its presence. While all PDU tests with PET present were carried out over $575^{\circ} \mathrm{C}$, no significant coking was observed. No streams with PET concentrations over $20 \%$ were tested. 
TABLE 4

Operational Summary of PDU Tests

\begin{tabular}{|c|c|c|c|c|c|c|c|c|c|c|c|}
\hline Run No. & P035 & P036 & P037 & P038 & P039 & $\mathrm{P} 040$ & P04IA & P041B & $\mathrm{PO42}$ & $\mathrm{PO43}$ & P044 \\
\hline Feed Mix & $\mathbf{B b}^{\mathbf{C}}$ & BB & BB & $\mathbf{B b}^{\circ}$ & $\mathrm{BB} / \mathrm{PVC}^{\mathrm{C}}$ & $\mathrm{PCI}^{\star}$ & $\mathrm{PC2}^{\circ}$ & PC2 & PC2 & PC2 & PC2 \\
\hline $\begin{array}{l}\text { Temperature. } \\
{ }^{\circ} \mathrm{C}\end{array}$ & 495 & 625 & 625 & 625 & 625 & 625 & 575 & 625 & 625 & 625 & 590 \\
\hline $\begin{array}{c}\text { Starting Bed } \\
\text { Material }\end{array}$ & Sand & $\begin{array}{c}\text { Sand } \\
\text {. }\end{array}$ & Sand & $\mathrm{CaO}$ & $\mathrm{CaO}$ & Sand & Sand & Sand & Sand & Sand & Sand \\
\hline $\begin{array}{l}\text { Liquid } \\
\text { Character }\end{array}$ & Wax' & Fluid & Fluid & Fluid & Fluid & Fluid & Wax & Viscous" & Viscous-Solid & Viscous & Viscous \\
\hline Reactor Bed & \multicolumn{11}{|c|}{ Black with no agglomeration ${ }^{\text {h }}$} \\
\hline $\begin{array}{l}\text { Feed } \\
\text { Position }\end{array}$ & Side $1 / 2$ in. & Side $1 / 2$ in. & Side $1 / 2$ in. & Side $*$ in. & Side $*$ in. & Side $*$ in. & Bottom 1 in. & Bottom 1 in. & Bottom 1 in. & Bottom 1 in. & Bottom 1 in. \\
\hline $\begin{array}{c}\text { Shutdown } \\
\text { Status }\end{array}$ & Quench' & Feed & Feed & Scheduled ${ }^{*}$ & Feed" & Feed & Equip.' & Equip. ${ }^{m}$ & Feed & Equip." & Equip.• \\
\hline $\mathrm{HCN}$ & NA & NA & NA & NA & NA & Unknown & Yes & Yes & Yes & Yes & Yes \\
\hline $\begin{array}{l}\text { 5\% sand as be } \\
\text { - } 5 \% \text { CaO addec } \\
\text { - } 95 \% \text { base blen } \\
\text { Postconsumer } \\
\text { - Postconsumer } \\
\text { Liquid consiste } \\
\text { - Liquid consiste } \\
\text { Approximately } \\
\text { Wax buildup in } \\
\text { Plastic melting } \\
\text { Testing contin } \\
\text { Air compress } \\
\text { - Loss of feed n } \\
\text { - Oomputer rese } \\
\text { Overheating o }\end{array}$ & $\begin{array}{l}\text { makeup. } \\
\text { as bed makeu } \\
5 \% \text { PVC; } 1 \\
\text { lend } 11 ; \text { main } \\
\text { lend } n 2 ; 59.2 \\
\text { cy was waxy. } \\
\text { cy was much } \\
0.5 \% \text { carbon } \\
\text { the quench sy } \\
\text { in the feed tub } \\
\text { ed to next set } \\
\text { malfunction. } \\
\text { be coolant. } \\
\text { causing emer } \\
\text { reactor shell }\end{array}$ & $\begin{array}{l}\text { CaO added } \\
\text { HDPE, with } \\
\text { HDPE, 20.1 } \\
\text { ore viscous t } \\
\text { oduced by sut } \\
\text { em. } \\
\text { conditions w } \\
\text { ncy shutdow } \\
\text { to a sefract }\end{array}$ & $\begin{array}{l}\text { s bed makeup } \\
\text { 1\% PP and } \\
\text { PET, 0.6\% } \\
\text { an previously } \\
\text { toich combus } \\
\text { h no interrupt } \\
\text { procedure init } \\
\text { gap. }\end{array}$ & $\begin{array}{l}\text { L } 1 \% \text { PS poss } \\
\text { VC, 10.7\% P. } \\
\text { een. } \\
\text { on in burner. } \\
\text { n. } \\
\text { tion. }\end{array}$ & $\begin{array}{l}5 \% \mathrm{CaO} \\
7 \% \mathrm{PS}, 4\end{array}$ & $\begin{array}{l}\text { ed makeup } \\
\text { LDPE; } 15\end{array}$ & $\begin{array}{l}\text { sed on histor } \\
\mathrm{CaO} \text { as bed } \mathrm{n}\end{array}$ & $\begin{array}{l}\text { assay. } \\
\text { cup. }\end{array}$ & & & \\
\hline
\end{tabular}


TABLE 5

Chlorine Analysis and Balance for P039

\begin{tabular}{lcc}
\hline & \multicolumn{2}{c}{ Cl Concentration, ppm } \\
\cline { 2 - 3 } Feed Material & P039 & P041 \\
Bed Material & 25,000 & 28,000 \\
Solids Receiver & 54 & 8300 \\
Secondary Cyclone & 13 & 4000 \\
Organic Liquids & 3.2 & NA \\
\hline
\end{tabular}

TABLE 6

$\mathrm{CaO}$ Conversion

\begin{tabular}{llll}
\hline & & Start & End \\
\cline { 2 - 4 } P038 & $\%$ Volatile & 1.94 & 29 \\
& $\% \mathrm{CaCO}_{3}$ & 4.4 & 65 \\
P039 & $\%$ Volatile & 1.94 & 20 \\
& $\% \mathrm{CaCO}_{3}$ & 4.4 & 45 \\
P041 & $\%$ Volatile & 1.94 & 13 \\
Solids Receiver & $\% \mathrm{CaCO}_{3}$ & 4.4 & 30 \\
P041 & $\% \mathrm{Volatile}$ & 1.94 & 27 \\
Bed Material & $\% \mathrm{CaCO}_{3}$ & 4.4 & 62 \\
\hline
\end{tabular}

Simulated boiling point distributions for Tests P036-P039, P041, and P044 are shown in Figure 3, along with some common fuels for comparison. Liquids from the tests using postconsumer plastics were noticeably heavier those produced from the base blend. Possibilities considered for the heaviness of the liquids made from postconsumer material included 1) insufficient solids residence time (due to the presence of PET), 2) $\mathrm{CaO}$ fines carryover, 3 ) formation of calcium terephthalate or other organic acid-calcium compounds (from PET decomposition), 4) insufficient gas residence time, 5) coking, and 6) presence of materials in the postconsumer mix that affect decomposition of the mix. Analysis of the liquids and solid residuals from the tests (especially P042) indicated that gas residence time was the most likely cause of the heavier-than-desired liquid product. To clarify gas residence time effect, a series of tests were run on the bench-scale CFBR unit. A residence effect was observed, both on gas and liquid quality, and is discussed briefly in Section 9.0.

Also of concern was whether or not steam is an important variable. Most work prior to the PDU program was performed without steam. Earlier work was done on the CFBR, which has indirect heaters. The PDU, on the other hand, relies on a natural gas-fired burner for 


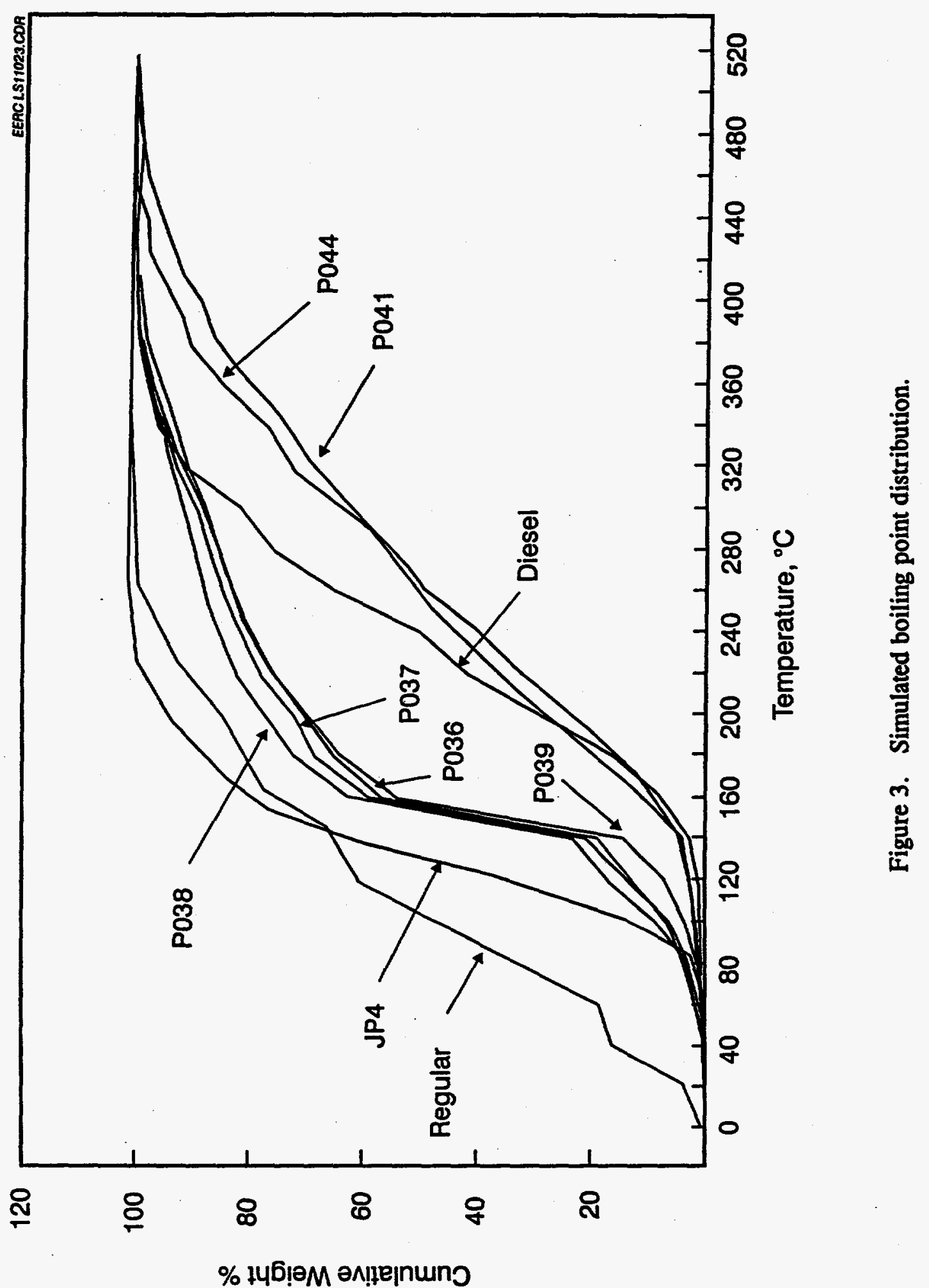


process heat, a by-product of which is water. While steam was added in some CFBR tests involving PET, the effect of steam on liquid production from other plastics was not studied. CFBR work indicated that a high steam content is desirable when PET is present. Steam was added to the PDU in some tests, mainly in order to determine condensation train heat load capability. In anticipation of a maximum $30 \%$ PET content, $30 \mathrm{lb} / \mathrm{hr}$ of steam was used. Based on the residence time study (Section 9.0), it appears that steam has a beneficial effect, producing a lighter boiling point distribution for a given gas residence time at $625^{\circ} \mathrm{C}$.

While the PDU and CFBR have been seen to produce similar yields in the pyrolysis of coal, some difference exist, mainly in gas residence times and fluidization velocities. Gas residence time on the PDU can be simulated in the CFBR, but will be at different gas fluidization velocities. The PDU maintains higher fluidization velocities for a given gas residence time, relative to the CFBR. While the two units have similar length-to-diameter ratios (L/Ds), 15 for the PDU and 11 for the CFBR (bottom section measurement), the (heated) cyclones and piping to the condensation train on the PDU are longer than on the CFBR.

\subsection{Week 1}

Operating conditions and product yields for tests run during Week 1 are shown in Table 7. P035 was performed at a temperature of $495^{\circ} \mathrm{C}$. As expected, processing at this temperature produced a waxy liquid, and heavy wax formation was observed in the condensation train. The system was shut down after 2.25 hours to clean out the quench train. Plastics feed was occasionally interrupted during this test because of plugging in the feed tube.

Temperature was increased to $650^{\circ} \mathrm{C}$ in the next test (P036) and fluidization velocity decreased, in an attempt to lighten product liquids. This test went well, and a 3-hour balance period was completed. The balance period was terminated when the feed tube plugged. The feed tube was cleared, the feed material rescreened to eliminate large pieces of feed that had passed through the first screening, and Run P037 begun. Feed was maintained for P037 for approximately 6 hours, during which a 2-hour balance period was completed. As with P036, the balance period was terminated prematurely because of feed tube plugging.

The condensation train of the PDU consists of a sieve tower and two water spray quench venturi scrubbers. Initial plans called for organic liquids to be condensed mainly in the sieve tower, light organics and some water in the first water scrubber, and water in the second water scrubber. The sieve tower uses cooled, condensed, process liquids as a cooling fluid. For start-up, mixed xylenes, with a $2 \%$ by weight anisole tracer, were used in the sieve tower. During operation, it was discovered that that level was difficult to maintain in the sieve tower and that a constant sieve tower outlet temperature was maintained (approximately $95^{\circ} \mathrm{C}$ ). Upon reflection, it became apparent that a water/xylene azeotrope was forming. In addition, many of the organic components produced from thermal depolymerization of plastics form azeotropes with water. In subsequent tests, water was used as a start-up fluid for both the sieve tower and water scrubbers. Xylene was used in Tests P035-P037. Xylene is subtracted from all simulated boiling point distributions for these tests (by use of the tracer fluid). After Run P037, water was used as a start-up fluid for both the sieve tower and the water scrubbers. 


\section{TABLE 7}

Shakedown (Week 1) Tests

\begin{tabular}{|c|c|c|c|}
\hline \multicolumn{4}{|c|}{ Test Conditions } \\
\hline Run Number & P035 & P036 & P037 \\
\hline Feed Mix & $\begin{array}{l}\text { Base blend with } \\
5 \% \text { sand }\end{array}$ & $\begin{array}{l}\text { Base blend with } \\
5 \% \text { sand }\end{array}$ & $\begin{array}{l}\text { Base blend with } \\
5 \% \text { sand }\end{array}$ \\
\hline Bed Material & Sand & Sand & Sand \\
\hline Temperature ${ }^{\circ} \mathrm{C}$ & 495 & 650 & 625 \\
\hline Pressure, psig & 20 & 40 & 30 \\
\hline Fluidization Velocity, $\mathrm{ft} / \mathrm{s}^{\mathrm{b}}$ & 5 & 4 & 4 \\
\hline Steam, $\mathrm{lb} / \mathrm{hr}$ & 30 & 30 & 0 \\
\hline Feed Rate, lb/hr & 100 & 80 & 100 \\
\hline Duration of Feed, hre & 2.25 & 8.5 & 6.0 \\
\hline Balance Period, hr ${ }^{d}$ & 0 & 3 & 2.5 \\
\hline \multicolumn{4}{|c|}{ Product Yields, wt $\%$} \\
\hline Liquid & Not available (NA) & 33 & 26 \\
\hline Gas + Water & NA & 64 & 74 \\
\hline Solids & NA & 3 & 0 \\
\hline$C_{2}=+C_{3}=+C_{4}=$ Yield & NA & 41 & 46 \\
\hline
\end{tabular}

$5 \%$ by weight of the feed material was sand for bed makeup.

- Fluidization velocity is based on incoming gas only. Gas produced during the reaction is not accounted for.

- Duration of feed refers to the length of time over which plastics were fed to the unit for the specified test.

d A balance period is the length of continuous time over which steady-state material balance information is collected.

- A natural gas burner is used for process heat, which generates combustion gases and water. Gas composition exiting the burner is not measured.

Simulated boiling point distributions for Tests P036 and P037 are shown in Figure 3, along with some common fuels for comparison. Tabular listings of product liquid components are given in Table 8. 
TABLE 8

Tabular Listings of Product Liquid Components GC Simulated Distillation Data, Start-Up Fluid-Free, 5-20-94

\begin{tabular}{lccccc}
\hline \multicolumn{6}{c}{ GC Simulated Distillation Data, Start-Up Fluid-Free, 5-20-94 } \\
\hline & $\begin{array}{c}\text { Retention } \\
\text { Index }\end{array}$ & $\begin{array}{c}\text { Retention } \\
\text { Time, min }\end{array}$ & ID & $\begin{array}{c}\text { P036 } \\
\text { WS1 } 1+2 \\
\text { Balance }\end{array}$ & $\begin{array}{c}\text { P037 } \\
\text { WS1 +2 } \\
\text { Balance }\end{array}$ \\
\hline BPI, ${ }^{\circ} \mathrm{C}$ & 589.0 & 8.623 & C6 olefin & 0.6 & 1.6 \\
83.4 & 650.3 & 10.623 & Benzene & 1.7 & 3.6 \\
95.1 & 689.1 & 11.886 & C7 olefin & 0.7 & 2 \\
114.0 & 757.7 & 13.968 & toluene & 4.3 & 8.4 \\
122.6 & 789.1 & 14.909 & C8 olefin & 0.9 & 2 \\
139.2 & 854.4 & 16.730 & Ethylbenzene & 4.9 & 8 \\
146.4 & 883.2 & 17.518 & Styrene & 35.5 & 42 \\
147.9 & 889.2 & 17.685 & C9 olefin & 1.1 & 1.6 \\
167.7 & 973.3 & 19.826 & C1 styrene & 2.8 & 2.8 \\
171.4 & 989.3 & 20.231 & C10 olefin & 2 & 2.4 \\
182.8 & 1040.1 & 21.435 & Indene & 1 & 1.2 \\
193.7 & 1089.3 & 22.584 & C11 olefin & 1.3 & 1.2 \\
213.4 & 1186.3 & 24.705 & Naphthalene & 1 & 1.2 \\
\hline
\end{tabular}

\subsection{Week 2}

Test points completed in Week 2 are shown in Table 9. After successfully processing base blend in sand, $\mathrm{CaO}$ was used (P038) as a bed material. Some concern existed over the possible attrition of $\mathrm{CaO}$, since the fluidization velocity in the PDU is much higher than in the CFBR. While some fines carryover was observed, this did not prove to be of significance. The feed tube was increased in diameter to $3 / 4$ in. (it was $1 / 2$ in. for P035-P037) for P038, in an attempt to eliminate the feed tube plugs experienced in previous runs. With the $3 / 4$-in. tube, feed was maintained for $\mathbf{1 8 . 5}$ hours, and an 8-hour balance period completed. After completion of the 8-hour run, system parameters were changed so that $\mathrm{P} 039$ could be run.

P039 used a 5\% PVC/95\% base blend mixture as feed material. A soda ash solution (pH 12) was added to the second water scrubber to capture $\mathrm{HCl}$ released during PVC decomposition. This test was terminated after 5 hours because of bed agglomeration. Upon dropping the bottom of the reactor, it was found that three of the six nozzles on the gas distributor plate had eroded or corroded away. This plate is located at the bottom of the bed, immediately after the natural gas burner. The three possible explanations considered for the nozzle failure were corrosion (from PVC), erosion (from high transport velocities), or corrosion (because of a rich burner). As mentioned, the feed material for this test was introduced via the side of the reactor. (Figure 2). The high velocity of the pneumatically transported feed material caused impingement on the distributor plate, which may have, over time, eroded away sufficient metal to cause the failure. This test was the first to introduce PVC into the system. One scenario envisioned PVC decomposition to $\mathrm{HCl}$ at the bottom of the bed, before thorough mixing with the $\mathrm{CaO}$ bed material. An alternative scenario considered was that PVC decomposed at the bottom of the bed and that the $\mathrm{CaO}$ in this region may have been 
TABLE 9

Week 2 Tests

\begin{tabular}{|c|c|c|c|}
\hline \multicolumn{4}{|c|}{ Test Conditions } \\
\hline Run Number & $\mathrm{PO} 038$ & P039 & $\mathrm{P} 040$ \\
\hline Feed Mix & $\begin{array}{l}\text { Base blend (BB) with } \\
5 \% \text { sand as bed } \\
\text { makeup) }\end{array}$ & $\begin{array}{l}\mathrm{BB} / \mathrm{PVC}(95 / 5) \\
\text { (with 5\% } \mathrm{CaO} \text { as } \\
\text { bed makeup) }\end{array}$ & $\begin{array}{l}\text { Postconsumer" (with } \\
5 \% \mathrm{CaO} \text { as bed } \\
\text { makeup) }\end{array}$ \\
\hline Bed Material & $\mathrm{CaO}$ & $\mathrm{CaO}$ & Sand \\
\hline Temperature ${ }^{\circ} \mathrm{C}$ & 625 & 625 & 625 \\
\hline Pressure, psig & 44 & 36 & 40 \\
\hline Fluidization Velocity, $\mathrm{ft} / \mathrm{s}^{\mathrm{b}}$ & 4 & 4 & 4 \\
\hline Steam, lb/hr & 30 & 30 & 30 \\
\hline Feed Rate, $\mathrm{lb} / \mathrm{hr}$ & 100 & 100 & 75 \\
\hline Duration of Feed, hre & 18.5 & 5 & 5.5 \\
\hline Balance Period, $\mathrm{hr}^{\mathrm{d}}$ & 8 & 1.5 & 0 \\
\hline \multicolumn{4}{|c|}{ Product Yields, wt\% } \\
\hline Liquid & 53 & NA & NA \\
\hline Gas + Water & 47 & NA & NA \\
\hline Solids & 0 & NA & NA \\
\hline$C_{2}=+C_{3}=+C_{4}=$ & 31 & NA & NA \\
\hline
\end{tabular}

a Mostly HDPE, some PP, PS.

b Fluidization velocity is based on incoming gas only. Gas produced during the reaction is not accounted for.

c Duration of feed refers to the length of time over which plastics were fed to the unit for the specified test.

d A balance period is the length of continuous time over which steady state material balance information is collected.

converted to $\mathrm{CaCO}_{3}$ from the relatively high concentrations of $\mathrm{CO}_{2} \cdot \mathrm{CaCO}_{3}$ has been observed to be ineffective in chlorine capture during thermal depolymerization (1). The $\mathrm{HCl}$, at temperatures in excess of $625^{\circ} \mathrm{C}$, would attack the stainless steel distributer plate. The third scenario examined as a possibility was that the stainless steel of the distributor plate was insufficient for the high temperatures it experienced. Normally, a Hastalloy plate is used for this application. Because of changing the feed location to the side of the unit, an older plate, made of stainless steel, was used. In an attempt to lower the fluidization gas (and lengthen gas residence time), the burner was run slightly lean. Temperature at the plate was estimated to be approximately $982^{\circ}-1093^{\circ} \mathrm{C}\left(1800^{\circ}-2000^{\circ} \mathrm{F}\right)$. This temperature is not overly problematic in a reducing atmosphere. In order to determine which of the possible reasons considered was responsible for the distributor plate failure, proximate analyses were taken of material on the 
plate and further up in the bed, and an SEM analysis was performed on the metal which had flaked off from the plate. The proximate analyses, shown in Table 10, indicate that very little carbonate material is present in the area of the distributor plate, but the bed material higher up (around TC 305) has large quantities of volatile matter (likely carbonate) present. The SEM analysis (listed in tabular form in Appendix D) indicated no chlorine at all, but did indicate several highly oxidized species. The conclusion was, therefore, that the high oxygen content of the burner corroded the plate to the point of failure.

P040 was the first test in the PDU using postconsumer plastics as a feed material. This particular postconsumer plastics feed stream consisted mainly of polyethylenes, with the possibility of some $(<1 \%)$ PP and PS present. During this test, numerous feed problems were experienced, and the test was terminated so that the feed system could be reconfigured.

\subsubsection{Product Liquids}

Component analyses for Tests P038 and P039 are given in Table 11. Styrene, from polystyrene decomposition, is found in high concentrations in both samples. Figure 3 shows the simulated boiling point distributions for these two tests, along with those from gasoline and diesel fuel as comparisons.

\subsubsection{Chlorine Analyses}

Chlorine concentration of the various streams from Run P039 are given in Table 12. Methods used for chlorine analysis and their accuracies are given in Appendix B.

\subsection{Week 3}

\subsubsection{Summary}

Week 3 tests conditions and yields are listed in Table 13. These two tests used a postconsumer plastics blend that reportedly consisted of $59.2 \%$ HDPE, $10.7 \% \mathrm{PP}, 4.7 \%$ LDPE, $4.7 \%$ PS, $20.1 \%$ PET, $0.6 \%$ PVC, based on results of a solvent dissolution method described in Appendix A.

TABLE 10

Proximate Analyses for P039 Bed Material Samples, wt\%

\begin{tabular}{lcccc}
\hline & \multicolumn{5}{c}{ Volatile } \\
Sample & Moisture & Matter & Fixed Carbon & Ash \\
\hline Agglomerate on distributor plate & 0.0 & 0.2 & 0 & 99.8 \\
Agglomerate at TC 304 & 0.0 & 0.6 & 0 & 99.4 \\
Agglomerate at TC 305 & 0.7 & 21.7 & 0 & 77.6 \\
Agglomerate above TC 305 & 0.2 & 30.8 & 0 & 69.0 \\
\hline
\end{tabular}


TABLE 11

Component Analyses for P038-P039

GC Simulated Distillation Data, 5-20-94

(No organic acids detected under GC conditions used)

\begin{tabular}{|c|c|c|c|c|c|}
\hline & & & & $\begin{array}{c}\text { P038 } \\
\text { WS1 +2 } \\
\text { Balance } \\
\text { GW 482 } \\
\end{array}$ & $\begin{array}{c}\text { P039 } \\
\text { WS1 +2 } \\
\text { Balance }\end{array}$ \\
\hline $\mathrm{BPI},{ }^{\circ} \mathrm{C}$ & $\begin{array}{c}\text { Retention } \\
\text { Index }\end{array}$ & $\begin{array}{l}\text { Retention } \\
\text { Time, min }\end{array}$ & ID & $\begin{array}{c}\mathrm{GC} \\
\text { area\% } \\
\end{array}$ & $\begin{array}{c}\mathrm{GC} \\
\text { area\% }\end{array}$ \\
\hline 65.4 & 589.0 & 8.623 & C6 olefin & 0.8 & 0.6 \\
\hline 83.7 & 650.3 & 10.623 & Benzene & 1.5 & 0.8 \\
\hline 87.2 & 662.2 & 11.009 & C6 olefin & 0.3 & 0.2 \\
\hline 91.1 & 675.5 & 11.441 & C6 olefin & 0.3 & 0.2 \\
\hline 95.1 & 689.1 & 11.886 & C7 olefin & 0.9 & 0.7 \\
\hline 114.0 & 757.7 & 13.968 & Toluene & 4.8 & 2.7 \\
\hline 122.6 & 789.1 & 14.909 & C8 olefin & 1.2 & 1.0 \\
\hline 139.2 & 854.4 & 16.730 & Ethylbenz. & 5.1 & 3.2 \\
\hline 146.4 & 883.2 & 17.518 & Styrene & 39.0 & 35.2 \\
\hline 147.9 & 889.2 & 17.685 & C9 olefin & 1.5 & 1.5 \\
\hline 154.9 & 918.3 & 18.442 & C3 benzene & 0.7 & 0.6 \\
\hline 159.3 & 937.5 & 18.926 & MW 118 & 0.5 & 0.5 \\
\hline 162.0 & 948.8 & 19.209 & C3 benzene & 0.7 & 0.6 \\
\hline 167.7 & 973.3 & 19.826 & C1 styrene & 3.3 & 3.1 \\
\hline 168.5 & 976.9 & 19.908 & C10 olefin & & \\
\hline 171.4 & 989.3 & 20.231 & C10 olefin & 2.7 & 3.0 \\
\hline 175.7 & 1008.2 & 20.691 & C4 benzene & 0.6 & 0.5 \\
\hline 177.9 & 1018.1 & 20.922 & Cl styrene & 0.9 & 0.8 \\
\hline 182.8 & 1040.1 & 21.435 & Indene & 1.0 & 0.9 \\
\hline 184.0 & 1045.5 & 21.550 & & & \\
\hline 191.3 & 1078.3 & 22.327 & C11 olefin & 0.6 & 0.9 \\
\hline 193.7 & 1089.3 & 22.584 & C11 olefin & 1.9 & 2.3 \\
\hline 196.0 & 1099.7 & 22.826 & $\mathrm{nCl1}$ & 0.3 & \\
\hline 206.1 & 1149.9 & 23.915 & $\mathrm{Cl}$ indene & 0.6 & 0.6 \\
\hline 211.8 & 1178.4 & 24.532 & $\mathrm{C} 12$ olefin & & 0.8 \\
\hline 213.4 & 1186.3 & 24.705 & Naphthalene & 0.9 & 1.0 \\
\hline 214.0 & 1189.3 & 24.770 & C12 olefin & 1.3 & 1.7 \\
\hline 215.8 & 1198.6 & 24.958 & $\mathrm{nC} 12$ & & \\
\hline 231.5 & 1279.1 & 26.602 & C13 olefin & 0.5 & 0.8 \\
\hline 233.5 & 1289.4 & 26.812 & C13 olefin & 1.1 & 1.4 \\
\hline
\end{tabular}


Table 11 (continued)

\begin{tabular}{|c|c|c|c|c|c|}
\hline $\mathrm{BPI},{ }^{\circ} \mathrm{C}$ & $\begin{array}{l}\text { Retention } \\
\text { Index }\end{array}$ & $\begin{array}{l}\text { Retention } \\
\text { Time, min }\end{array}$ & ID & $\begin{array}{c}\text { GC } \\
\text { area\% } \\
\end{array}$ & $\begin{array}{c}\mathrm{GC} \\
\text { area \% }\end{array}$ \\
\hline 235.3 & 1298.5 & 26.983 & $\mathrm{nC13}$ & & \\
\hline 239.0 & 1319.3 & 27.392 & C1 naphth. & 0.3 & \\
\hline 249.7 & 1379.8 & 28.540 & C14 olefin & 0.6 & 1.0 \\
\hline 251.5 & 1389.7 & 28.727 & C14 olefin & 1.0 & 1.3 \\
\hline 253.2 & 1399.5 & 28.913 & nC14 & 0.2 & 0.3 \\
\hline 267.2 & 1480.5 & 30.354 & C15 olefin & 0.3 & 0.6 \\
\hline 268.9 & 1490.3 & 30.528 & C15 olefin & 0.8 & 1.2 \\
\hline 270.6 & 1499.7 & 30.695 & $\mathrm{nC} 15$ & 0.2 & 0.3 \\
\hline 283.7 & 1581.1 & 32.067 & C16 olefin & 0.3 & 0.6 \\
\hline 285.2 & 1590.6 & 32.226 & C16 olefin & 0.6 & 0.9 \\
\hline 286.7 & 1599.7 & 32.380 & $\mathrm{nC} 16$ & 0.1 & 0.2 \\
\hline 299.3 & 1681.6 & 33.686 & C17 olefin & 0.3 & 0.5 \\
\hline 300.8 & 1690.8 & 33.833 & C17 olefin & 0.4 & 0.7 \\
\hline 302.2 & 1699.7 & 33.975 & $\mathrm{nC} 17$ & 0.1 & 0.2 \\
\hline 314.1 & 1781.9 & 35.223 & C18 olefin & 0.3 & 0.5 \\
\hline 315.4 & 1790.7 & 35.357 & C18 olefin & 0.4 & 0.7 \\
\hline 316.6 & 1799.1 & 35.485 & $\mathrm{nC} 18$ & 0.1 & 0.3 \\
\hline 328.1 & 1882.3 & 36.680 & C19 olefin & 0.2 & 0.4 \\
\hline 329.3 & 1890.9 & 36.803 & C19 olefin & 0.4 & 0.7 \\
\hline 330.5 & 1899.2 & 36.922 & $\mathrm{nC} 19$ & 0.1 & 0.5 \\
\hline 341.6 & 1982.8 & 38.069 & C20 olefin & 0.2 & 0.4 \\
\hline 342.7 & 1990.9 & 38.180 & C20 olefin & 0.3 & 0.5 \\
\hline 344.0 & 2000.8 & 38.314 & $\mathrm{nC} 20$ & 0.3 & 0.8 \\
\hline 354.7 & 2084.5 & 39.391 & C21 olefin & 0.2 & 0.4 \\
\hline 355.8 & 2092.6 & 39.495 & C21 olefin & 0.2 & 0.4 \\
\hline 356.7 & 2100.4 & 39.595 & $\mathrm{nC} 21$ & 0.0 & 0.3 \\
\hline 367.0 & 2184.3 & 40.657 & C22 olefin & 0.1 & 0.4 \\
\hline 367.9 & 2191.8 & 40.751 & C22 olefin & 0.2 & 0.4 \\
\hline 368.8 & 2199.1 & 40.843 & $\mathrm{nC} 22$ & 0.0 & 0.6 \\
\hline 378.3 & 2284.7 & 41.867 & C23 olefin & 0.1 & 0.3 \\
\hline 379.1 & 2291.9 & 41.953 & C23 olefin & 0.2 & 0.3 \\
\hline 379.9 & 2299.0 & 42.038 & $\mathrm{nC23}$ & 0.0 & 0.5 \\
\hline 389.4 & 2384.6 & 43.070 & C24 olefin & 0.1 & 0.3 \\
\hline 390.2 & 2391.8 & 43.157 & C24 olefin & 0.2 & 0.3 \\
\hline 390.9 & 2397.9 & 43.231 & $\mathrm{nC} 24$ & & 0.5 \\
\hline 400.3 & 2486.8 & 44.351 & C25 olefin & 0.1 & 0.2 \\
\hline 401.1 & 2494.1 & 44.442 & C25 olefin & 0.2 & 0.3 \\
\hline 401.7 & 2499.7 & 44.513 & $\mathrm{nC} 25$ & & 0.1 \\
\hline 412.1 & 2597.7 & 45.749 & C26 olefin & 0.1 & 0.2 \\
\hline \multirow[t]{2}{*}{412.9} & 2605.4 & 45.846 & C26 olefin & 0.1 & 0.2 \\
\hline & & & Total & 82.5 & 83.9 \\
\hline
\end{tabular}




\section{TABLE 12}

Chlorine Analyses for P039

\begin{tabular}{lc}
\hline & $\mathrm{Cl}$ Concentration, mg/g \\
\cline { 2 - 2 } Feed Material & 5000 \\
Bed Material & 54 \\
Solids Receiver & 13 \\
Secondary Cyclone & 3.2 \\
Organic Liquids & $<0.1$ \\
Water & $200 \mathrm{mg} / \mathrm{L}$ \\
\hline
\end{tabular}

TABLE 13

Week 3 Tests

\begin{tabular}{lcc}
\hline & Test Conditions & \\
\hline Run Number & P04l-A & P041-B \\
\hline Feed Mix & Postconsumer with & Postconsumer with \\
& $15 \%$ CaO & $15 \%$ CaO \\
Bed Material & Sand & Sand \\
Temperature, ${ }^{\circ} \mathrm{C}$ & 575 & 625 \\
Pressure, psig & 40 & 40 \\
Fluidization Velocity, ft/s ${ }^{2}$ & 4 & 4 \\
Steam, lb/hr & 30 & 30 \\
Feed Rate, lb/hr & 100 & 100 \\
Duration of Feed, hr & 2 & 9 \\
Balance Period, hr & 0 & 6 \\
\hline & Product Yields, wt\% & 63 \\
\hline Liquid & NA & 22 \\
Gas + Water & NA & 15 \\
Solids & NA & 35 \\
$\mathrm{C}_{2}=+\mathrm{C}_{3}=+\mathrm{C}_{4}=$ & NA & \\
\hline
\end{tabular}

- Fluidization velocity is based on incoming gas only. Gas produced during the reaction is not accounted for.

b Duration of feed refers to the length of time over which plastics were fed to the unit for the specified test.

c A balance period is the length of continuous time over which steady-state material balance information is collected. 
Prior to the start of P041, the 1/2-in. feed tube was replaced with a $3 / 4$-in. tube, in an attempt to eliminate the persistent feed tube plugging problems experienced throughout the first two weeks of testing. Additionally, feed was introduced into the bottom of the reactor, as per the suggestion of the fluid-bed scaleup consultants. A water jacket was added to the feed tube so that the plastic feed would not melt in the tube before reaching the bed. Initial tests used $-3 / 8$-in. feed material. This size of postconsumer plastic flake produced severe bridging in the feed system. The $3 / 8$-in. material would not flow from a vertical 4-in. pipe into the feed hopper. The feed was subsequently resized to $-1 / 4$ in., and attempts at feeding continued. While periodic plugging of the feed tube was experienced during this run, the test was terminated because a leak developed in the water jacket of the cooling tube surrounding the feed tube. This significant repair caused testing to be terminated for the remainder of the week.

\subsubsection{Liquids}

A simulated boiling point distribution for a composite sample from $\mathrm{P} 041$ is given in Figure 3, and component analysis for the test is given in Table 14.

\subsection{3 $\mathrm{HCN}$}

During Test P041, hydrogen cyanide (HCN) was detected in the product gas stream and in the vents from the water scrubber collection barrels. A sodium bicarbonate solution was maintained in the water scrubbers in anticipation of $\mathrm{HCN}$ formation. Actual HCN levels are not known, as the meter used for detection has an upper detection limit of $100 \mathrm{ppm}$, and all readings were off scale. $\mathrm{HCN}$ levels in the liquid product was measured to be $1.16 \mathrm{mg} / \mathrm{L}$, and in the liquid "sludge" (heavier liquid layer), $\mathrm{HCN}$ was measured to be $10.7 \mu \mathrm{g} / \mathrm{g}$.

\subsubsection{Metals}

Several streams from P041 were analyzed for metals content to gain insight into the distribution of metals during thermal decomposition. Analyses for those streams tested are given in Table 15.

TABLE 14

Component Analysis for P041

GC Simulated Distillation Data, 5-20-94 (no organic acids detected under GC conditions used)

\begin{tabular}{lcccc}
\hline & & & & $\begin{array}{c}\text { P041 } \\
\text { Balance }\end{array}$ \\
\hline BPI, ${ }^{\circ} \mathrm{C}$ & $\begin{array}{c}\text { Retention } \\
\text { Index }\end{array}$ & $\begin{array}{c}\text { Retention } \\
\text { Time, min }\end{array}$ & ID & $\begin{array}{c}\text { GC } \\
\text { area \% }\end{array}$ \\
\hline 65.4 & 589.0 & 8.623 & C6 olefin & 0.2 \\
83.7 & 650.3 & 10.623 & Benzene & 0.6 \\
87.2 & 662.2 & 11.009 & C6 olefin & 0.1 \\
91.1 & 675.5 & 11.441 & C6 olefin & 0.1 \\
\hline
\end{tabular}


Table 14 (continued)

\begin{tabular}{|c|c|c|c|c|}
\hline $\mathrm{BPI},{ }^{\circ} \mathrm{C}$ & $\begin{array}{c}\text { Retention } \\
\text { Index }\end{array}$ & $\begin{array}{l}\text { Retention } \\
\text { Time, min }\end{array}$ & ID & $\begin{array}{c}\mathrm{GC} \\
\text { area \% }\end{array}$ \\
\hline$\overline{95.1}$ & 689.1 & 11.886 & C7 olefin & 0.3 \\
\hline 114.0 & 757.7 & 13.968 & Toluene & 0.5 \\
\hline 122.6 & 789.1 & 14.909 & C8 olefin & 0.6 \\
\hline 139.2 & 854.4 & 16.730 & Ethylbenzene & 0.4 \\
\hline 146.4 & 883.2 & 17.518 & Styrene & 1.6 \\
\hline 147.9 & 889.2 & 17.685 & C9 olefin & 1.2 \\
\hline 154.9 & 918.3 & 18.442 & C3 benzene & \\
\hline 159.3 & 937.5 & 18.926 & MW 118 & 0.2 \\
\hline 162.0 & 948.8 & 19.209 & C3 benzene & 0.1 \\
\hline 167.7 & 973.3 & 19.826 & C1 styrene & \\
\hline 168.5 & 976.9 & 19.908 & C10 olefin & 0.8 \\
\hline 171.4 & 989.3 & 20.231 & C10 olefin & 3.5 \\
\hline 175.7 & 1008.2 & 20.691 & C4 benzene & \\
\hline 177.9 & 1018.1 & 20.922 & Cl styrene & \\
\hline 182.8 & 1040.1 & 21.435 & Indene & 0.2 \\
\hline 184.0 & 1045.5 & 21.550 & & 1.7 \\
\hline 191.3 & 1078.3 & 22.327 & C11 olefin & 1.1 \\
\hline 193.7 & 1089.3 & 22.584 & C11 olefin & 4.0 \\
\hline 196.0 & 1099.7 & 22.826 & $\mathrm{nC} 11$ & 0.6 \\
\hline 206.1 & 1149.9 & 23.915 & $\mathrm{Cl}$ indene & \\
\hline 211.8 & 1178.4 & 24.532 & C12 olefin & 1.6 \\
\hline 213.4 & 1186.3 & 24.705 & Naphthalene & \\
\hline 214.0 & 1189.3 & 24.770 & C12 olefin & 3.6 \\
\hline 215.8 & 1198.6 & 24.958 & $\mathrm{nC} 12$ & 0.7 \\
\hline 231.5 & 1279.1 & 26.602 & Cl3 olefin & 1.8 \\
\hline 233.5 & 1289.4 & 26.812 & $\mathrm{C} 13$ olefin & 3.5 \\
\hline 235.3 & 1298.5 & 26.983 & $\mathrm{nC13}$ & 0.8 \\
\hline 239.0 & 1319.3 & 27.392 & C1 nphtln. & \\
\hline 249.7 & 1379.8 & 28.540 & C14 olefin & 3.2 \\
\hline 251.5 & 1389.7 & 28.727 & C14 olefin & 3.7 \\
\hline 253.2 & 1399.5 & 28.913 & $\mathrm{nC} 14$ & 0.5 \\
\hline 267.2 & 1480.5 & 30.354 & C15 olefin & 1.6 \\
\hline 268.9 & 1490.3 & 30.528 & C15 olefin & 3.0 \\
\hline 270.6 & 1499.7 & 30.695 & $\mathrm{nCl5}$ & 0.6 \\
\hline 283.7 & 1581.1 & 32.067 & C16 olefin & 1.6 \\
\hline 285.2 & 1590.6 & 32.226 & C16 olefin & 2.4 \\
\hline 286.7 & 1599.7 & 32.380 & $\mathrm{nC16}$ & 0.5 \\
\hline 299.3 & 1681.6 & 33.686 & C17 olefin & 1.4 \\
\hline 300.8 & 1690.8 & 33.833 & C17 olefin & 2.0 \\
\hline 302.2 & 1699.7 & 33.975 & $\mathrm{nC} 17$ & 0.4 \\
\hline 314.1 & 1781.9 & 35.223 & C18 olefin & 1.4 \\
\hline 315.4 & 1790.7 & 35.357 & C18 olefin & 2.0 \\
\hline 316.6 & 1799.1 & 35.485 & $\mathrm{nC} 18$ & 0.3 \\
\hline 328.1 & 1882.3 & 36.680 & C19 olefin & 1.3 \\
\hline
\end{tabular}


Table 14 (continued)

\begin{tabular}{|c|c|c|c|c|}
\hline $\mathrm{BPI},{ }^{\circ} \mathrm{C}$ & $\begin{array}{l}\text { Retention } \\
\text { Index }\end{array}$ & $\begin{array}{l}\text { Retention } \\
\text { Time, min }\end{array}$ & ID & $\begin{array}{c}\mathrm{GC} \\
\text { area \% }\end{array}$ \\
\hline 329.3 & 1890.9 & 36.803 & C19 olefin & 1.9 \\
\hline 330.5 & 1899.2 & 36.922 & nC19 & 0.4 \\
\hline 341.6 & 1982.8 & 38.069 & C20 olefin & 1.3 \\
\hline 342.7 & 1990.9 & 38.180 & C20 olefin & 1.6 \\
\hline 344.0 & 2000.8 & 38.314 & $\mathrm{nC} 20$ & 0.4 \\
\hline 354.7 & 2084.5 & 39.391 & C21 olefin & 1.2 \\
\hline 355.8 & 2092.6 & 39.495 & C21 olefin & 1.5 \\
\hline 356.7 & 2100.4 & 39.595 & $\mathrm{nC} 21$ & 0.3 \\
\hline 367.0 & 2184.3 & 40.657 & C22 olefin & 1.1 \\
\hline 367.9 & 2191.8 & 40.751 & C22 olefin & 1.3 \\
\hline 368.8 & 2199.1 & 40.843 & $\mathrm{nC} 22$ & 0.3 \\
\hline 378.3 & 2284.7 & 41.867 & C23 olefin & 1.0 \\
\hline 379.1 & 2291.9 & 41.953 & C23 olefin & 1.2 \\
\hline 379.9 & 2299.0 & 42.038 & $\mathrm{nC} 23$ & 0.4 \\
\hline 389.4 & 2384.6 & 43.070 & C24 olefin & 0.9 \\
\hline 390.2 & 2391.8 & 43.157 & C24 olefin & 1.1 \\
\hline 390.9 & 2397.9 & 43.231 & $\mathrm{nC} 24$ & 0.4 \\
\hline 400.3 & 2486.8 & 44.351 & C25 olefin & 0.8 \\
\hline 401.1 & 2494.1 & 44.442 & C25 olefin & 1.0 \\
\hline 401.7 & 2499.7 & 44.513 & $\mathrm{nC} 25$ & 0.2 \\
\hline 412.1 & 2597.7 & 45.749 & C26 olefin & 0.7 \\
\hline 412.9 & 2605.4 & 45.846 & C26 olefin & 0.9 \\
\hline 413.1 & 2609.3 & 45.885 & $\mathrm{nC} 26$ & 0.2 \\
\hline 422.0 & 2697.8 & 47.259 & C27 olefin & 0.7 \\
\hline 422.6 & 2704.6 & 47.374 & C27 olefin & 0.8 \\
\hline 423.1 & 2709.0 & 47.453 & $\mathrm{nC} 27$ & 0.2 \\
\hline 431.5 & 2797.7 & 49.022 & C28 olefin & 0.6 \\
\hline 432.1 & 2804.4 & 49.152 & C28 olefin & 0.7 \\
\hline 432.5 & 2808.7 & 49.240 & $\mathrm{nC28}$ & 0.2 \\
\hline 440.4 & 2897.8 & 51.052 & C29 olefin & 0.5 \\
\hline 441.0 & 2904.9 & 51.196 & C29 olefin & 0.6 \\
\hline 441.5 & 2909.9 & 51.298 & $\mathrm{nC} 29$ & 0.1 \\
\hline 450.8 & 3014.2 & 53.419 & C30 olefin & 0.4 \\
\hline 451.4 & 3021.6 & 53.570 & C30 olefin & 0.5 \\
\hline 451.9 & 3027.5 & 53.690 & $\mathrm{nC} 30$ & 0.1 \\
\hline 462.8 & 3149.8 & 56.177 & C31 olefin & 0.4 \\
\hline 463.6 & 3158.6 & 56.357 & C31 olefin & 0.4 \\
\hline 477.1 & 3309.8 & 59.432 & C32 olefin & 0.3 \\
\hline 478.0 & 3319.8 & 59.635 & C32 olefin & 0.3 \\
\hline 493.9 & 3498.6 & 63.272 & C33 olefin & 0.2 \\
\hline 494.9 & 3510.6 & 63.516 & C33 olefin & 0.2 \\
\hline 513.8 & 3722.8 & 67.833 & C34 olefin & 0.2 \\
\hline \multirow[t]{2}{*}{515.0} & 3735.6 & 68.093 & C34 olefin & 0.2 \\
\hline & & & Total & 83.2 \\
\hline
\end{tabular}


TABLE 15

P041 Metals and $\mathrm{Cl}$ Analyses

\begin{tabular}{lccccc}
\hline & $\mathrm{V}, \mu \mathrm{g} / \mathrm{g}$ & $\mathrm{Ni}, \mu \mathrm{g} / \mathrm{g}$ & $\mathrm{Fe}, \mu \mathrm{g} / \mathrm{g}$ & $\mathrm{Cu}, \mu \mathrm{g} / \mathrm{g}$ & $\mathrm{Cl}, \mathrm{mg} / \mathrm{g}$ \\
\cline { 2 - 7 } Plastics Feed & $<5$ & $<10$ & 200 & $<10$ & 28 \\
$\mathrm{CaO}$ & 5.44 & $<10$ & 2170 & $<10$ & 0.052 \\
Product Oils (WS 1\&2) & $<5$ & $<10$ & 200 & $<10$ & 28 \\
Water (WS 1\&2) & NA & NA & NA & NA & $910 \mathrm{mg} / \mathrm{L}$ \\
Water (sieve tower) & NA & NA & NA & NA & $360 \mathrm{mg} / \mathrm{L}$ \\
Bed Material & NA & NA & NA & NA & 8.3 \\
Solids Receiver & NA & NA & NA & NA & 4.0 \\
\hline
\end{tabular}

Not analyzed.

\subsection{Week 4}

After the cooling jacket for the feed tube was modified for Week 4 to include an expansion joint, a 16-hr balance period was completed for P042. Conditions and yields for this test and for P043 are shown in Table 16. Slight feed tube plugging was observed in P042, but did not force interruption of the test. Two incidents were recorded, in which it was believed

\section{TABLE 16}

Week 4 Tests Test Conditions

\begin{tabular}{|c|c|c|}
\hline Run Number & $\mathrm{P} 042$ & P043 \\
\hline Feed Mix & Postconsumer w/15\% CaO & Postconsumer $w / 15 \% \mathrm{CaO}$ \\
\hline Bed Material & Sand & Sand \\
\hline Temperature, ${ }^{\circ} \mathrm{C}$ & 625 & 625 \\
\hline Pressure, psig & 45 & 45 \\
\hline Fluidization Velocity, $\mathrm{ft} / \mathrm{s}^{2}$ & 4.5 & 4.5 \\
\hline Steam, $\mathrm{lb} / \mathrm{hr}$ & 32 & 30 \\
\hline Feed Rate, lb/hr & 50 & 50 \\
\hline Duration of Feed, $h r^{b}$ & 23 & 3 \\
\hline Balance Period, hre & 16 & - \\
\hline \multicolumn{3}{|c|}{ Product Yields, wt\% } \\
\hline Liquid & 27 & NA \\
\hline Gas + Water & 73 & NA \\
\hline Solids & 0 & NA \\
\hline$C_{2}=+C_{3}=+C_{4}=$ & 24 & NA \\
\hline
\end{tabular}

- Fluidization velocity is based on incoming gas only. Gas produced during the reaction is not accounted for.

- Duration of feed refers to the length of time over which plastics were fed to the unit for the specified test.

c A balance period is the length of continuous time over which steady-state material balance information is collected. 
that the feed tube plugged momentarily, but material broke through, and the test was continued. Two 8-hr balance periods were completed. At the start of the third 8-hr balance period, the feed tube plugged, and the test was terminated to clean out the feed system. The feed system was cleaned out, and testing resumed at the same conditions (P043). "Liquids" produced from P042 were quite heavy, and several analytical tests were run to determine the cause of the poor liquid quality. Several theories were put forth, including 1) the possibility of terephthalic or other organic acid formation, 2) $\mathrm{CaO}$ fines carryover, 3) incomplete decomposition (short gas residence time), 4) unknown substances entering the process with the postconsumer feed (e.g., paper) that do not decompose at the same conditions as the plastics, and 5) coking. As a start, proximate analyses of the liquid from P042 were performed. Results of these analyses are shown in Table 17, and Figure 4 shows the volatile decomposition temperature profile of the sample. The proximate analyses indicate a high amount of ash. Some fixed carbon is indicated, but this may be generated by the analytical procedure, which measures volatiles by heating the sample to $950^{\circ} \mathrm{C}$ prior to the fixed-carbon measurement. The high ash level in initial proximate analyses could have been explained by either the presence of $\mathrm{CaO}$ fines, coked material, or organic acids. TGA, as well as a THF (tetrahydrofuran) solubility (to check the fines level) and organic acids quantification were also performed on a composite sample.

Details of these analyses are given in Appendix E. This more in-depth analysis indicated about $40 \%$ partially reacted polymer material, about $3 \%$ organic acid content, and less than $5 \%$ highly carbonized (coked) material. Based on these findings, insufficient gas residence time was judged to be the primary reason for the unsatisfactory liquid character.

Early in Test P043, the computer controlling the PDU was inadvertently shut off, initiating an emergency shutdown procedure. The depressurization that occurred during the emergency shutdown caused liquids in the quench to surge, coating pipes downstream of the cooling train and up to the flare. When the system was restarted, the organics coating these pipes started to produce a mist over the parking lot of the EERC. When the misting problem was discovered, testing was terminated so that these pipes could be thoroughly cleaned out. In the event of any such future disturbances, two coke scrubbers were placed after the condensation system to remove any entrained vapors that might escape the quench train.

As with P041, HCN was detected at levels higher than the upper detection limit for the $\mathrm{HCN}$ meter during P042. This is a concern, since the bicarbonate solutions in the water scrubbers should have captured most of the HCN generated.

\section{TABLE 17}

P042 Sieve Tower Proximate Analyses

\begin{tabular}{lccc}
\hline & Sample No. 1 & Sample No. 2 & Sample No. 3 \\
\cline { 2 - 4 } Moisture, wt\% & 17.95 & 31.98 & 32.13 \\
Volatile Matter, wt\% & 38.04 & 36.35 & 47.91 \\
Fixed Carbon, wt\% & 5.65 & 5.11 & 4.97 \\
Ash, wt\% & 38.36 & 26.57 & 14.99 \\
\hline
\end{tabular}



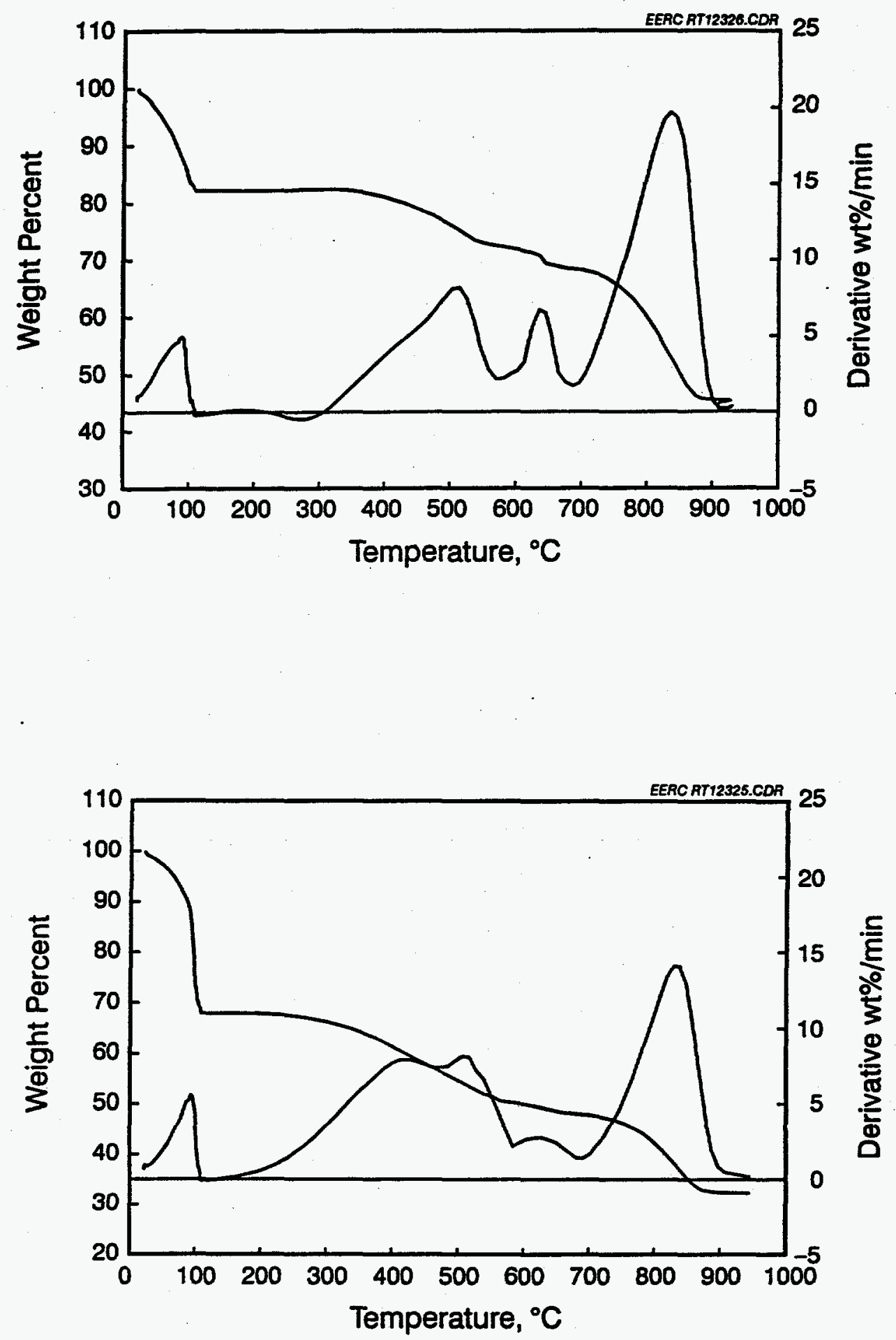

Figure 4. TGA profiles of three samples of P042 liquids recovered from sieve tower. 


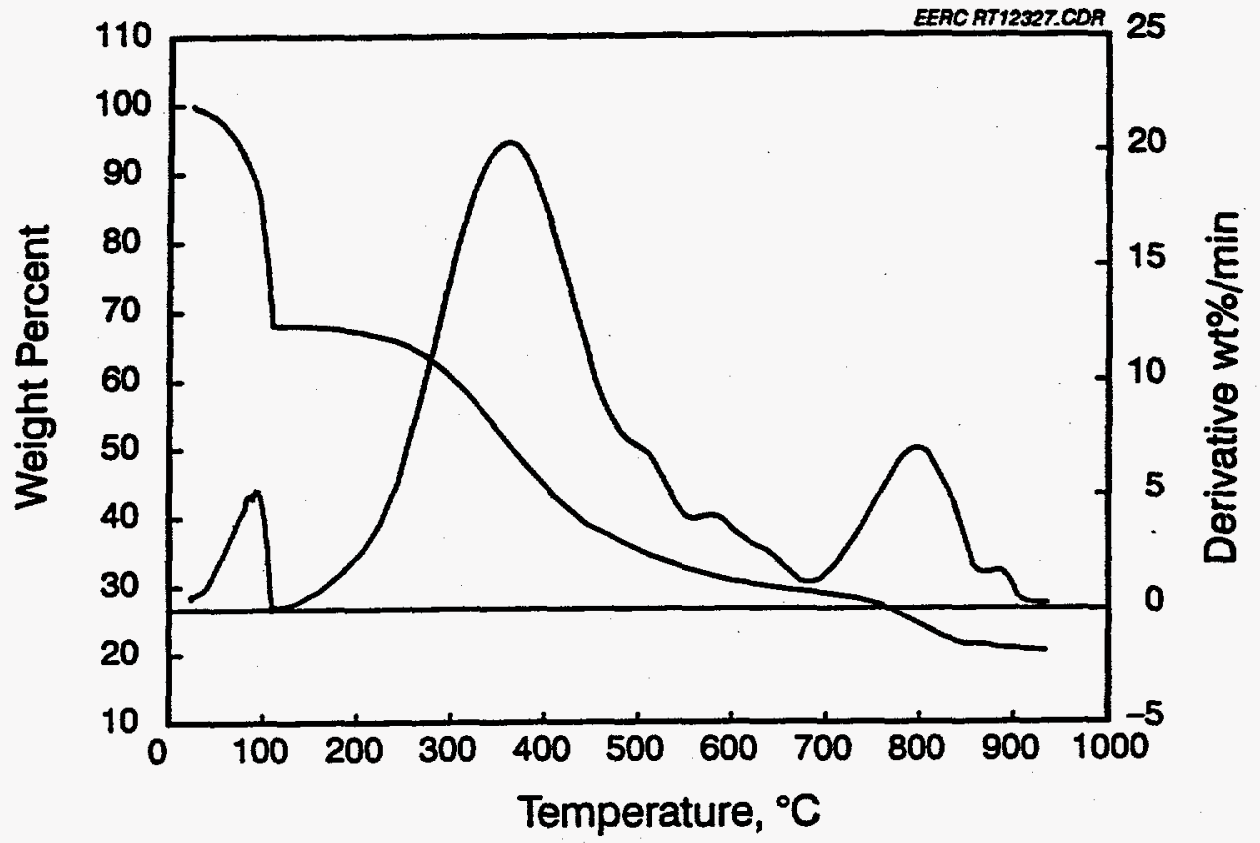

Figure 4. Continued.

\subsection{Week 5}

\subsubsection{Summary}

Conditions and yields for the last test in this phase of this phase of the PDU program, P044, are shown in Table 18. This test went well, with no feed problems experienced. An uneventful 8-hr balance period was completed. After completion of the balance period, the test was terminated because of unacceptably high skin temperatures on the bottom section of the reactor. The high skin temperatures were due to refractory failure in the vicinity of a recently replaced thermowell, located on the lower bottom section. It is thought that vapor from the burner gas channeled through a crack in the refractory in this area.

\subsubsection{Liquids}

A simulated boiling point distribution for P044 is shown in Figure 3, and a component analysis is given for the product liquids in Table 19. Liquid yields are low for this test, as excess air was added to lower the fluidization velocity (and increase gas residence time) by burning some feed material for heat.

\subsection{COMPOSITE LIQUIDS}

A composite sample of product liquids was analyzed to determine the appropriateness of sending the material to a refinery. The simulated-boiling point distribution is shown in 
Figure 5. Since Runs P035-P037 used xylene as a start-up fluid for the quench system, the region where xylene boils is disproportionately represented. Figure 5 also shows what this distribution would be if the xylene had not been added. The xylene content was calculated, based on the concentration of anisole, which was added to the xylene as a tracer. Significant properties of the composite liquids are given in Table 20, and Table 21 is a component breakdown of the composite liquids.

\section{TABLE 18}

Week 5 Tests

\begin{tabular}{|c|c|}
\hline \multicolumn{2}{|c|}{ Test Conditions } \\
\hline Run Number & P044 \\
\hline Feed Mix & Postconsumer with 7\% $\mathrm{CaO}$ \\
\hline Bed Material & Sand \\
\hline Temperature, ${ }^{\circ} \mathrm{C}$ & 590 \\
\hline Pressure, psig & 50 \\
\hline Fluidization Velocity, $\mathrm{ft} / \mathrm{s}^{\mathrm{a}}$ & 3.4 \\
\hline Steam, lb/hr & 0 \\
\hline Feed Rate, lb/hr & 68 \\
\hline Duration of Feed, $\mathbf{h r} \mathbf{r}^{\mathbf{b}}$ & 15 \\
\hline Balance Period, $\mathrm{hr}^{\mathrm{e}}$ & 8 \\
\hline \multicolumn{2}{|c|}{ Product Yields, wt\% } \\
\hline Liquid & 18 \\
\hline Gas + Water & 79 \\
\hline Solids & 4 \\
\hline $\mathrm{C}_{2}=+\mathrm{C}_{3}=+\mathrm{C}_{2}=$ & 16 \\
\hline
\end{tabular}

Fluidization velocity is based on incoming gas only. Gas produced during the reaction is not accounted for.

b Duration of feed refers to the length of time over which plastics were fed to the unit for the specified test.

c A balance period is the length of continuous time over which steady-state material balance information is collected.

TABLE 19

Product Liquid Analysis for P044

\begin{tabular}{lcccc}
\hline Identification & $\mathrm{BPI},{ }^{\circ} \mathrm{C}$ & $\begin{array}{c}\text { Retention } \\
\text { Index }\end{array}$ & $\begin{array}{c}\text { Retention } \\
\text { Time, min }\end{array}$ & $\begin{array}{c}\text { P044 } \\
\text { Conc., \% }\end{array}$ \\
\hline $\mathrm{C}_{6} \mathrm{H}_{12}$ & 65.2 & 588.6 & 8.610 & 0.17 \\
Benzene & 83.7 & 650.3 & 10.620 & 0.40 \\
$\mathrm{C} 7$ or $\mathrm{C} 8$ & 87.1 & 661.9 & 11.000 & $\mathrm{NI}$ \\
$\mathrm{C} 7$ or $\mathrm{C} 8$ & 95.0 & 688.9 & 11.876 & 0.37 \\
\hline
\end{tabular}


Table 19 (continued)

\begin{tabular}{|c|c|c|c|c|}
\hline Identification & $\mathrm{BPI},{ }^{\circ} \mathrm{C}$ & $\begin{array}{c}\text { Retention } \\
\text { Index }\end{array}$ & $\begin{array}{l}\text { Retention } \\
\text { Time, min }\end{array}$ & $\begin{array}{c}\text { P044 } \\
\text { Conc., \% }\end{array}$ \\
\hline Toluene & 114.0 & 757.3 & 13.955 & 0.50 \\
\hline $\mathrm{C}_{8} \mathrm{H}_{16}$ & 122.6 & 788.9 & 14.900 & 0.81 \\
\hline Ethylbenzene & 139.0 & 853.7 & 16.702 & 0.54 \\
\hline$m$-, $p$-Xylene & 141.1 & 862.1 & 16.933 & 0.42 \\
\hline Styrene & 145.7 & 880.2 & 17.428 & 0.97 \\
\hline$o$-Xylene & 147.0 & 885.6 & 17.575 & 0.38 \\
\hline $\mathrm{C}_{9} \mathrm{H}_{18}$ & 147.9 & 889.2 & 17.673 & 1.90 \\
\hline $\mathrm{C}_{10} \mathrm{H}_{20}$ & 171.4 & 989.3 & 20.219 & 4.35 \\
\hline \multirow[t]{2}{*}{ Indene } & 182.8 & 1040.2 & 21.424 & 0.37 \\
\hline & 184.0 & 1045.6 & 21.550 & 1.45 \\
\hline $\mathrm{C}_{11} \mathrm{H}_{22}$ & 193.8 & 1089.6 & 22.574 & 3.98 \\
\hline $\mathrm{C}_{11} \mathrm{H}_{24}$ & 196.1 & 1100.2 & 22.822 & 1.34 \\
\hline C1 Indene & 206.1 & 1150.1 & 23.902 & 0.46 \\
\hline C1 Indene & 207.2 & 1155.5 & 24.019 & 0.46 \\
\hline Naphthalene & 213.4 & 1186.7 & 24.695 & 0.38 \\
\hline $\mathrm{C}_{12} \mathrm{H}_{24}$ & 214.0 & 1189.7 & 24.760 & 3.33 \\
\hline $\mathrm{C}_{12} \mathrm{H}_{26}$ & 216.1 & 1200.2 & 24.987 & 1.46 \\
\hline $\mathrm{C}_{13} \mathrm{H}_{26}$ & 233.7 & 1290.1 & 26.805 & 3.45 \\
\hline $\mathrm{C}_{13} \mathrm{H}_{28}$ & 235.9 & 1301.6 & 27.035 & 1.81 \\
\hline \multirow[t]{2}{*}{ C1 Naphthalene } & 239.1 & 1320.0 & 27.384 & 0.40 \\
\hline & 250.0 & 1381.2 & 28.545 & 1.07 \\
\hline $\mathrm{C}_{14} \mathrm{H}_{28}$ & 251.6 & 1390.4 & 28.720 & 3.30 \\
\hline $\mathrm{C}_{14} \mathrm{H}_{30}$ & 253.3 & 1400.3 & 28.907 & 1.56 \\
\hline $\mathrm{C}_{15} \mathrm{H}_{30}$ & 269.0 & 1490.6 & 30.520 & 3.13 \\
\hline \multirow[t]{2}{*}{$\mathrm{C}_{15} \mathrm{H}_{32}$} & 270.6 & 1500.2 & 30.691 & 1.62 \\
\hline & 283.7 & 1581.6 & 32.060 & 0.83 \\
\hline $\mathrm{C}_{16} \mathrm{H}_{32}$ & 285.2 & 1591.0 & 32.218 & 2.65 \\
\hline \multirow[t]{3}{*}{$\mathrm{C}_{16} \mathrm{H}_{34}$} & 286.7 & 1600.3 & 32.375 & 1.61 \\
\hline & 290.8 & 1626.5 & 32.796 & 0.49 \\
\hline & 299.4 & 1682.2 & 33.680 & 0.85 \\
\hline $\mathrm{C}_{17} \mathrm{H}_{34}$ & 300.8 & 1691.3 & 33.825 & 2.44 \\
\hline \multirow[t]{2}{*}{$\mathrm{C}_{17} \mathrm{H}_{36}$} & 302.2 & 1700.2 & 33.967 & 1.44 \\
\hline & 314.2 & 1782.7 & 35.215 & 0.74 \\
\hline $\mathrm{C}_{18} \mathrm{H}_{36}$ & 315.4 & 1791.3 & 35.346 & 2.29 \\
\hline
\end{tabular}


Table 19 (continued)

\begin{tabular}{lcccc}
\hline Identification & BPI, ${ }^{\circ} \mathrm{C}$ & $\begin{array}{c}\text { Retention } \\
\text { Index }\end{array}$ & $\begin{array}{c}\text { Retention } \\
\text { Time, min }\end{array}$ & $\begin{array}{c}\text { P044 } \\
\text { Conc.,\% }\end{array}$ \\
\hline $\mathrm{C}_{18} \mathrm{H}_{38}$ & 316.7 & 1800.1 & 35.478 & 1.31 \\
$\mathrm{C}_{19} \mathrm{H}_{38}$ & 329.4 & 1891.7 & 36.793 & 2.26 \\
$\mathrm{C}_{19} \mathrm{H}_{40}$ & 330.6 & 1900.2 & 36.915 & 1.36 \\
$\mathrm{C}_{20} \mathrm{H}_{40}$ & 342.8 & 1992.0 & 38.171 & 1.93 \\
$\mathrm{C}_{20} \mathrm{H}_{42}$ & 343.9 & 2000.2 & 38.283 & 1.34 \\
$\mathrm{C}_{21} \mathrm{H}_{42}$ & 355.8 & 2092.8 & 39.485 & 1.73 \\
$\mathrm{C}_{21} \mathrm{H}_{44}$ & 356.8 & 2100.6 & 39.586 & 1.19 \\
$\mathrm{C}_{22} \mathrm{H}_{44}$ & 368.0 & 2192.6 & 40.740 & 1.56 \\
$\mathrm{C}_{22} \mathrm{H}_{46}$ & 368.9 & 2200.1 & 40.834 & 1.17 \\
$\mathrm{C}_{23} \mathrm{H}_{46}$ & 379.2 & 2293.0 & 41.942 & 1.30 \\
$\mathrm{C}_{23} \mathrm{H}_{48}$ & 380.0 & 2300.3 & 42.028 & 1.05 \\
$\mathrm{C}_{24} \mathrm{H}_{48}$ & 390.3 & 2392.9 & 43.142 & 1.10 \\
$\mathrm{C}_{24} \mathrm{H}_{50}$ & 391.1 & 2400.2 & 43.230 & 0.89 \\
\hline
\end{tabular}

BPI = GC boiling point index.

Conc. $=$ Concentration .

NI = Not identified.

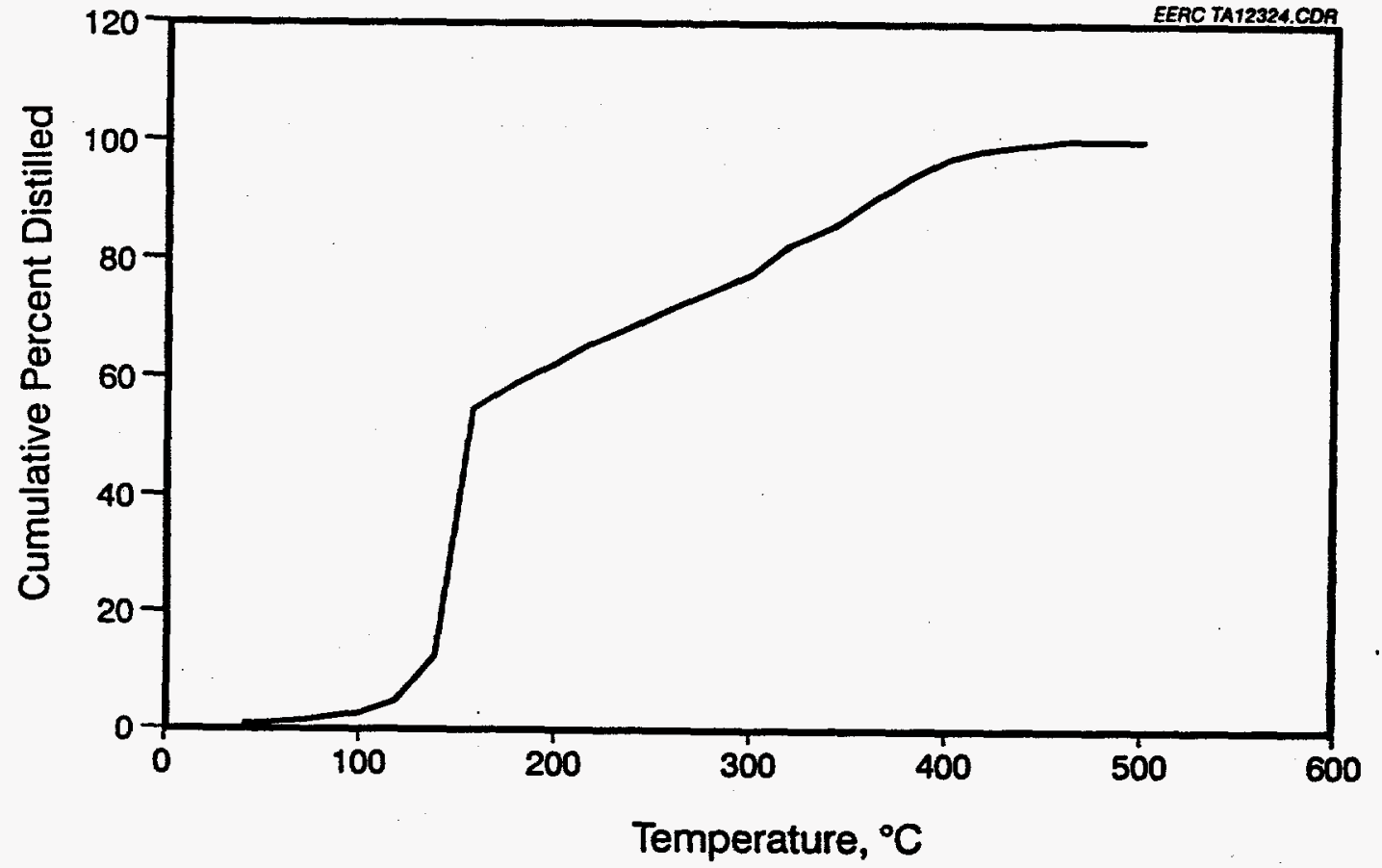

Figure 5. Simulated boiling point distribution and boiling point distribution minus xylene. 


\section{TABLE 20}

Properties of Plastics Decomposition Liquids Composite Sample

Flashpoint

Specific Gravity @ $20^{\circ} \mathrm{C}$

Chlorine

Fluorine

Bromine

Iron

Copper

Vanadium

Nickel

Sulfur

Nitrogen

$32^{\circ} \mathrm{C}$

0.91

Concentration, $\mu \mathrm{g} / \mathrm{g}$

43
$<30$
$<30$
30.5
$<10$
$<5$
$<10$
Concentration, wt\%
0.03
0.55

TABLE 21

Analysis of Big Reactor Composite Depolymerization Liquids

Sampled from 500-gal Steel Tank on 7-27-94

Sample is about $60 \%$ aromatics, $40 \%$ olefins and aliphatics.

\begin{tabular}{lccc}
\hline & BPI, ${ }^{\circ} \mathrm{C}$ & $\begin{array}{c}\text { Retention Time, } \\
\min \end{array}$ & Conc., area\% \\
\hline $\mathrm{C}_{6} \mathrm{H}_{12}$ & 65.0 & 8.549 & 0.22 \\
Benzene & 83.3 & 10.540 & 0.49 \\
$\mathrm{C}_{7} \mathrm{H}_{14}$ & 94.8 & 11.806 & 0.31 \\
Toluene $\mathrm{C}_{8} \mathrm{H}_{16}$ & 113.5 & 13.869 & 1.48 \\
Ethylbenzene & 122.2 & 14.820 & 0.43 \\
$m-, p$-Xylene & 138.6 & 16.624 & 6.49 \\
Styrene & 140.9 & 16.869 & 19.37 \\
$o-X y l e n e$ & 145.4 & 17.360 & 14.50 \\
$\mathrm{C}_{9} \mathrm{H}_{18}$ & 146.6 & 17.500 & 5.83 \\
Anisole & 150.1 & 17.586 & 0.74 \\
C3 Benzene & 154.3 & 17.876 & 0.73 \\
\hline & & 18.340 & 0.32 \\
\end{tabular}




\begin{tabular}{|c|c|c|c|c|}
\hline & $\mathrm{BPI},{ }^{\circ} \mathrm{C}$ & $\begin{array}{c}\text { Retention Time, } \\
\text { min } \\
\end{array}$ & Conc., area \% & \\
\hline C1 Styrene & 167.1 & 19.715 & 1.35 & \\
\hline $\mathrm{C}_{10} \mathrm{H}_{20}$ & 170.9 & 20.125 & 1.36 & \\
\hline C1 Styrene & 177.3 & 20.815 & 0.40 & \\
\hline Indene & 182.2 & 21.323 & 0.49 & \\
\hline $\mathrm{C}_{11} \mathrm{H}_{22}$ & 193.2 & 22.476 & 1.15 & \\
\hline nC11 & 195.5 & 22.725 & 0.18 & \\
\hline C1 Indene & 205.5 & 23.800 & 0.36 & \\
\hline naphthalene & 212.7 & 24.585 & 0.67 & \\
\hline $\mathrm{C}_{12} \mathrm{H}_{24}$ & 213.4 & 24.660 & 1.01 & \\
\hline $\mathrm{nCl} 12$ & 215.5 & 24.885 & 0.25 & \\
\hline $\begin{array}{l}\mathrm{C}_{13} \mathrm{H}_{26} \\
\mathrm{nC} 13+\mathrm{Cl}\end{array}$ & 233.0 & 26.700 & 1.03 & \\
\hline naphthalene & 235.1 & 26.921 & 0.50 & \\
\hline Biphenyl & 249.2 & 28.430 & 0.79 & \\
\hline $\mathrm{C}_{14} \mathrm{H}_{28}$ & 250.9 & 28.614 & 1.07 & \\
\hline $\mathrm{nCl} 14$ & 252.6 & 28.804 & 0.37 & \\
\hline $\mathrm{C}_{15} \mathrm{H}_{30}$ & 268.2 & 30.413 & 1.07 & \\
\hline $\mathrm{nC} 15$ & 269.9 & 30.583 & 0.30 & \\
\hline $\mathrm{C}_{16} \mathrm{H}_{32}$ & 284.4 & 32.110 & 0.98 & \\
\hline $\mathrm{nCl6}$ & 285.9 & 32.266 & 0.28 & . \\
\hline $\mathrm{C}_{17} \mathrm{H}_{34}$ & 300.0 & 33.715 & 0.94 & \\
\hline $\mathrm{nC} 17$ & 301.4 & 33.859 & 0.28 & \\
\hline $\mathrm{C}_{18} \mathrm{H}_{36}$ & 314.6 & 35.237 & 1.02 & \\
\hline $\mathrm{nC} 18$ & 315.8 & 35.367 & 0.36 & \\
\hline $\mathrm{C}_{19} \mathrm{H}_{38}$ & 328.5 & 36.682 & 0.98 & \\
\hline $\mathrm{nC} 19$ & 329.7 & 36.803 & 0.40 & \\
\hline $\mathrm{C}_{20} \mathrm{H}_{40}$ & 341.9 & 38.060 & 0.85 & \\
\hline $\mathrm{nC20}$ & 343.0 & 38.173 & 0.92 & \\
\hline $\mathrm{C}_{21} \mathrm{H}_{42}$ & 355.1 & 39.371 & 0.82 & \\
\hline $\mathrm{nC} 21$ & 356.1 & 39.471 & 0.30 & \\
\hline $\mathrm{C}_{22} \mathrm{H}_{44}$ & 367.2 & 40.625 & 0.68 & \\
\hline $\mathrm{nC22}$ & 368.1 & 40.719 & 0.42 & \\
\hline $\mathrm{C}_{23} \mathrm{H}_{46}$ & 378.4 & 41.826 & 0.65 & \\
\hline $\mathrm{nC} 23$ & 379.2 & 41.911 & 0.51 & \\
\hline $\mathrm{C}_{24} \mathrm{H}_{48}$ & 389.4 & 43.015 & 0.65 & \\
\hline $\mathrm{nC24}$ & 390.2 & 43.101 & 0.55 & \\
\hline $\mathrm{C}_{25} \mathrm{H}_{50}$ & 400.5 & 44.281 & 0.47 & \\
\hline $\mathrm{nC} 25$ & 401.2 & 44.368 & 0.22 & \\
\hline $\mathrm{C}_{26} \mathrm{H}_{52}$ & 412.3 & 45.661 & 0.37 & \\
\hline \multirow[t]{2}{*}{$\mathrm{nC} 26$} & 413.1 & 45.753 & 0.16 & \\
\hline & & Total Identified & 76.07 & \\
\hline
\end{tabular}




\subsection{RESIDUAIS}

All available bed material, solids receiver, and primary and secondary cyclone analyses are listed in Table 22. Of particular interest is the $\mathrm{CaCO}_{3}$ content of the starting and ending bed material. Conversion of $\mathrm{CaO}$ to $\mathrm{CaCO}_{3}$ is of interest because the carbonate is ineffective for chlorine capture. Proximate analysis was performed by TGA. This method allows for identification of the volatile material. If volatile material is evolved exclusively above about $850^{\circ} \mathrm{C}$, it is assumed to be $\mathrm{CO}_{2}$ evolution. If a sharp weight loss is observed at $560^{\circ} \mathrm{C}$, the weight loss is assumed to be due to the evolution of water (from $\mathrm{Ca}[\mathrm{OH}]_{\mathfrak{b}}$ ). These evolutions are shown on the TGA graphs in Appendix F.

\subsection{CFBR RESIDENCE TIME STUDY}

In order to gain a better understanding of the effect of residence time on liquid yields and boiling point distribution, a series of tests were performed in the CFBR. Conditions of these tests and major product yields are shown in Table 23. All tests used postconsumer

\section{TABLE 22}

Residual Analyses

\begin{tabular}{|c|c|c|c|c|c|c|}
\hline \multirow{2}{*}{$\begin{array}{l}\text { Run } \\
\text { Number }\end{array}$} & \multirow[t]{2}{*}{ Description } & \multicolumn{4}{|c|}{ Proximate Analysis, wt\% (as-rec.) } & \multirow{2}{*}{$\begin{array}{c}\text { Chlorine } \\
\text { ppm }\end{array}$} \\
\hline & & Moisture & Volatile & Fixed Carbon & Ash & \\
\hline All Runs & $\mathrm{CaO}$ sorbent & & 1.94 & & 98.06 & 52 \\
\hline \multirow[t]{2}{*}{ P035 } & Bed material & 0.00 & 0.10 & 0.00 & 99.87 & \\
\hline & Secondary cyclone & 0.00 & 0.66 & 0.00 & 99.24 & \\
\hline \multirow[t]{2}{*}{ P036 } & Bed material & 0.00 & 0.01 & 0.00 & 99.99 & \\
\hline & Solids receiver & 0.00 & 0.43 & 0.00 & 99.53 & \\
\hline $\mathrm{P037}$ & Bed material & 0.00 & 0.38 & 0.00 & 99.61 & \\
\hline \multirow[t]{2}{*}{ P038 } & Solids receiver & 0.00 & 28.49 & 0.00 & 70.35 & \\
\hline & Secondary cyclone & 0.10 & 17.11 & 5.59 & 77.20 & \\
\hline \multirow[t]{3}{*}{ P039 } & Bed material & 0.10 & 20.07 & 0.00 & 79.93 & 54,000 \\
\hline & Solids receiver & 0.30 & 39.03 & 0.00 & 60.67 & 13,000 \\
\hline & Secondary cyclone & 0.20 & 25.57 & 9.45 & 64.78 & 3200 \\
\hline P041 & Bed material & 0.00 & 29.08 & 0.00 & 72.62 & 8200 \\
\hline . & Solids receiver & 0.10 & 13.99 & 0.00 & 86.67 & 4000 \\
\hline $\mathrm{P} 043$ & Bed material & 0.15 & 20.16 & 0.94 & 78.75 & \\
\hline
\end{tabular}


TABLE 23

Residence Time Study Results

\begin{tabular}{|c|c|c|c|c|c|c|c|}
\hline Run No. & M413 & M414 & M415 & M416 & M417 & M418 & M419 \\
\hline Residence Time, sec & 18 & 23 & 44 & 42 & 22 & 13 & 19 \\
\hline Temperature ${ }^{\circ} \mathrm{C}$ & 625 & 625 & 625 & 625 & 625 & 625 & 575 \\
\hline Pressure, psig & 35 & 35 & 35 & 35 & 35 & 35 & 35 \\
\hline Steam & Yes & Yes & Yes & No & No & No & No \\
\hline $\mathrm{CaO}, \mathrm{wt} \%$ & 15 & 5 & 15 & 15 & 15 & 15 & 15 \\
\hline \multicolumn{8}{|c|}{ Product Yields, wt\% } \\
\hline Liquid & 29 & 29 & 33 & 24 & 37 & 82 & 84 \\
\hline Gas + Water & 71 & 71 & 67 & 75 & 63 & 18 & 16 \\
\hline $\mathrm{C}_{2}=+\mathrm{C}_{3}=$ & 17 & 17 & 28 & 31 & 16 & 11 & 9 \\
\hline
\end{tabular}

plastics for a feed material (same composition as Tests P041-P044). Most of the tests were performed at $625^{\circ} \mathrm{C}$, as this temperature had been selected as typical for liquid production. A range of residence times were examined. Figure 6 shows the simulated boiling point distributions of the tests and for P044. Figure 7 shows the effect of residence time on liquid, gas, and $\mathrm{C}_{2}=+\mathrm{C}_{3}{ }^{=}$yield.

M415 and M416 represent tests with and without steam, all other conditions being roughly equivalent. The test with steam had a slightly lighter boiling point distribution, and a higher liquid yield.

M413 was run under conditions similar to P044. The product liquids of these two tests have nearly identical boiling point distributions. To find residence times that produced satisfactory liquid quality, a series of residence times were run (M416, M417, and M418), with all other conditions being roughly equivalent. As seen in Figure 7, liquid yield decreases with increased residence time at $625^{\circ} \mathrm{C}$, and gas yield correspondingly increases. While liquid yield decreases with increased residence time, the liquid boiling point distribution shifts toward lighter products, as seen in Figure 6. These tests seem to indicate that residence time, like temperature, can be used to shift liquid yields and character, although the effect appears to be less dramatic than with temperature. Tests M418 (13 seconds) and M419 (19 seconds), $50^{\circ} \mathrm{C}$ in temperature apart, had roughly equal liquid yields and boiling point distributions fairly close together.

Table 24 shows a component breakdown for M413-M419, based on GC-FID chromatograms. Of interest is the shift with residence time of aliphatic/olefins to aromatics in the liquids. 


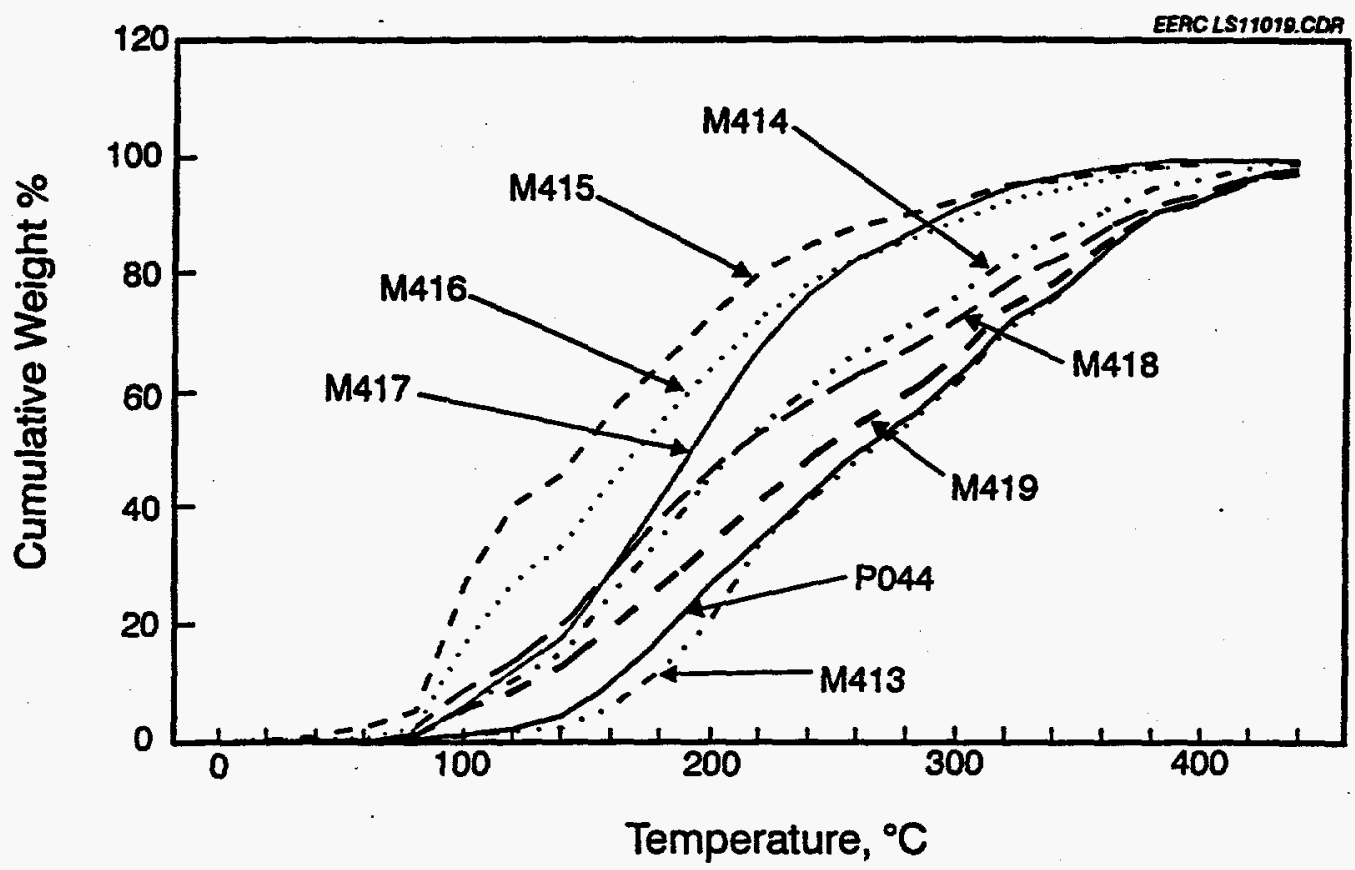

Figure 6. Simulated boiling point distribution for residence time series.

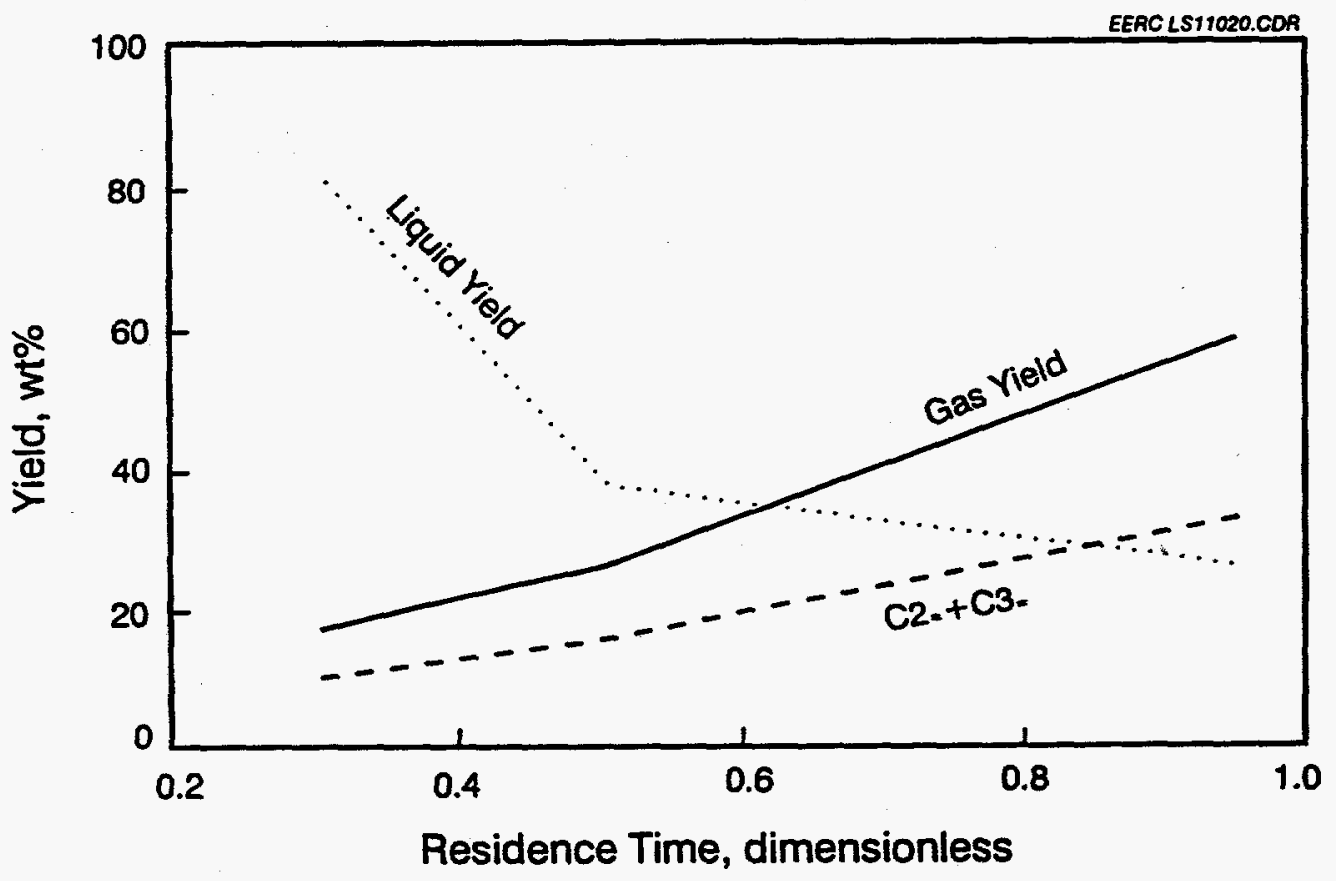

- $\quad$ Figure 7. Residence time, dimensionless. 


\section{Thermal Depolymerization of Plastics}

\subsection{SUMMARY}

The purposes of the PDU program are to 1) prove the fluid-bed thermal depolymerization of plastics conceptually on a commercially scalable unit, 2) identify engineering problems, 3) gather engineering data for scaleup, and 4) generate quantities of product for end-user qualification and evaluation. This first-phase effort has necessarily emphasized proof of concept and identification of engineering problems. The original system configuration and process conditions worked well for plastics of limited composition (i.e., the "base blend"), but longer gas residence times are necessary for processing postconsumer plastics, which have higher levels of PET and polyethylenes. In order to provide for longer gas residence times, the refractory in the bottom two sections of the PDU was removed and repoured to a 10-in. ID. Also, the pneumatic feed system was replaced with a dual auger arrangement, similar to that of the CFBR. This eliminates the large volume of cold transport gas used in the pneumatic method of feed introduction. No tests have been attempted in the PDU since completion of the modifications.

$\mathrm{CaO}$ attrition was not observed to be problematic at the fluidization velocities examined. Some $\mathrm{CaO}$ is converted to $\mathrm{CaCO}_{3}$, although the suitability of $\mathrm{CaO}$ for chlorine remediation is not yet decided. No operational problems were observed when $\mathrm{CaO}$ was used as a bed material.

PET levels of $20 \%$ caused no apparent operation difficulties. It is recommended that higher levels be tested.

Bench-scale tests indicate that gas residence time has an effect on both liquid quality and quantity, although to a lesser extent than process temperature. An earlier study (1) observed an effect on liquid quality, but minimal effect on yield. It should be noted that the tests described here cover a much wider range of residence times. This effect has been studied over a limited temperature range. At $625^{\circ} \mathrm{C}$ with steam, gas residence time needs to be above about 23 seconds to produce liquids of satisfactory quality.

\subsection{REFERENCES}

1. Sharp, L.L.; Ness, R.O.; Aulich, T.A.; Randall, J.C. "Thermal Depolymerization of Plastics," presented at the Canadian Chemical Engineering Conference, Ottawa, Canada, Oct. 3-6, 1993.

2. Sharp, L.L. "Thermal Recycling of 3M Products," final report for 3M Specialty Film Division/3M Traffic Control Division and U.S. DOE DE-FC21-93MC30098; EERC Publication 94-EERC-09-04, Dec. 1994. 
TABLE 24

Residence Time Study Component Analysis

\begin{tabular}{|c|c|c|c|c|c|c|c|c|c|c|c|c|c|c|c|}
\hline \multirow[b]{3}{*}{ Component } & \multirow[b]{3}{*}{$\begin{array}{c}\text { BPI, } \\
{ }^{\circ} \mathrm{C}\end{array}$} & \multirow{2}{*}{\multicolumn{2}{|c|}{$\begin{array}{c}\text { M413 } \\
\begin{array}{c}18 \text { seconds, } \\
\text { steam }\end{array}\end{array}$}} & \multirow{2}{*}{\multicolumn{2}{|c|}{$\begin{array}{c}\text { M414 } \\
\text { seconds, } \\
\text { steam }\end{array}$}} & \multirow{2}{*}{\multicolumn{2}{|c|}{$\begin{array}{c}\text { M415 } \\
\begin{array}{c}44 \text { seconds, } \\
\text { steam }\end{array} \\
\end{array}$}} & \multicolumn{2}{|c|}{ M416 } & \multicolumn{2}{|c|}{ M417 } & \multicolumn{2}{|c|}{ M418 } & \multicolumn{2}{|c|}{ M419 } \\
\hline & & & & & & & & \multicolumn{2}{|c|}{42 seconds } & \multicolumn{2}{|c|}{22 seconds } & \multicolumn{2}{|c|}{13 seconds } & \multicolumn{2}{|c|}{$\begin{array}{c}19 \text { seconds, } \\
575^{\circ} \mathrm{C} \\
\end{array}$} \\
\hline & & $w t \%$ & $\begin{array}{c}\% \\
\text { Yield }\end{array}$ & $w t \%$ & $\begin{array}{c}\% \\
\text { Yield }\end{array}$ & wt\% & $\begin{array}{c}\% \\
\text { Yield }\end{array}$ & wt\% & $\begin{array}{c}\% \\
\text { Yield }\end{array}$ & $w t \%$ & $\begin{array}{c}\% \\
\text { Yield }\end{array}$ & $w t \%$ & $\begin{array}{c}\% \\
\text { Yield }\end{array}$ & $w 1 \%$ & $\begin{array}{c}\% \\
\text { Yield }\end{array}$ \\
\hline \multicolumn{16}{|c|}{ Aromatics } \\
\hline Benzene & 83.7 & 0.51 & 0.15 & 2.91 & 0.84 & 16.87 & 5.57 & 11.48 & 2.87 & 3.52 & 1.30 & 3.17 & 2.60 & 2.18 & 1.83 \\
\hline Toluene & 114.0 & 0.54 & 0.16 & 3.45 & 1.00 & 11.38 & 3.76 & 8.68 & 2.17 & 5.10 & 1.89 & 2.64 & 2.16 & 1.73 & 1.45 \\
\hline Ethylbenzene & 139.0 & 0.38 & 0.11 & 1.67 & 0.48 & 3.08 & 1.02 & 3.26 & 0.82 & 2.86 & 1.06 & 1.20 & 0.98 & 1.11 & 0.93 \\
\hline$m$-, p-Xylene & 141.1 & 0.38 & 0.11 & 1.63 & 0.47 & 2.77 & 0.91 & 2.60 & 0.65 & 2.37 & 0.88 & 1.11 & 0.91 & 0.73 & 0.61 \\
\hline Styrene & 145.7 & 0.82 & 0.24 & 2.76 & 0.80 & 3.87 & 1.28 & 3.27 & 0.82 & 3.06 & 1.13 & 1.86 & 1.53 & 1.15 & 0.97 \\
\hline o-Xylene & 147.0 & 0.22 & 0.06 & 1.10 & 0.32 & 1.78 & 0.59 & 2.05 & 0.51 & 2.12 & 0.78 & 0.73 & 0.60 & 0.57 & 0.48 \\
\hline Indene & 182.8 & 0.29 & 0.08 & 1.03 & 0.30 & 1.90 & 0.63 & 1.84 & 0.46 & 2.52 & 0.93 & 0.50 & 0.41 & 0.37 & 0.31 \\
\hline C1 Indene & 206.1 & 1.21 & 0.35 & 1.17 & 0.34 & 1.51 & 0.50 & 1.67 & 0.42 & 2.20 & 0.81 & 0.51 & 0.42 & 0.70 & 0.59 \\
\hline Cl Indene & 207.2 & 1.10 & 0.32 & 1.01 & 0.29 & 1.39 & 0.46 & 1.42 & 0.36 & 2.09 & 0.77 & 0.49 & 0.40 & 0.54 & 0.45 \\
\hline Naphthalene & 213.4 & 0.56 & 0.16 & 1.30 & 0.38 & 1.97 & 0.65 & 2.29 & 0.57 & 3.11 & 1.15 & 0.39 & 0.32 & 0.39 & 0.33 \\
\hline $\begin{array}{l}\mathrm{C} 1 \\
\text { Naphthalene }\end{array}$ & 239.1 & 0.45 & 0.13 & 0.71 & 0.21 & 0.90 & 0.30 & 1.07 & 0.27 & 1.58 & 0.58 & 0.32 & 0.26 & 0.43 & 0.36 \\
\hline $\begin{array}{l}\text { Total } \\
\text { Aromatics } \\
\text { Identified }\end{array}$ & & 6.46 & & 18.75 & & 47.41 & & 39.62 & & 30.55 & & 12.91 & & 9.89 & \\
\hline \multicolumn{16}{|c|}{ Olefins and Aliphatics } \\
\hline Component & BPI & \multicolumn{2}{|c|}{ M413 } & \multicolumn{2}{|c|}{ M414 } & \multicolumn{2}{|c|}{ M415 } & \multicolumn{2}{|c|}{ M416 } & \multicolumn{2}{|c|}{ M417 } & \multicolumn{2}{|c|}{ M418 } & \multicolumn{2}{|c|}{ M419 } \\
\hline $\mathrm{C}_{6} \mathrm{H}_{12}$ & 65.2 & 0.10 & 0.03 & 0.56 & 0.16 & 1.47 & 0.49 & 0.93 & 0.23 & 0.45 & 0.17 & 1.06 & 0.87 & 0.79 & 0.66 \\
\hline $\mathrm{C7}$ or $\mathrm{CB}$ & 87.1 & NI & 0.00 & 0.25 & 0.07 & 1.06 & 0.35 & 0.43 & 0.11 & 0.18 & 0.07 & 0.38 & 0.31 & 0.26 & 0.22 \\
\hline
\end{tabular}


Table 24 (continued)

\begin{tabular}{|c|c|c|c|c|c|c|c|c|c|c|c|c|c|c|c|}
\hline \multirow{2}{*}{$\frac{\text { Component }}{\mathrm{C} 7 \text { or } \mathrm{C} 8}$} & \multirow{2}{*}{$\frac{\text { BPI }}{95.0}$} & \multicolumn{2}{|c|}{ M413 } & \multicolumn{2}{|c|}{ M414 } & \multicolumn{2}{|c|}{ M415 } & \multicolumn{2}{|c|}{ M416 } & \multicolumn{2}{|c|}{ M417 } & \multicolumn{2}{|c|}{ M418 } & \multicolumn{2}{|c|}{ M419 } \\
\hline & & 0.16 & 0.05 & 1.05 & 0.31 & 1.71 & 0.57 & 1.34 & 0.34 & 0.87 & 0.32 & 1.67 & 1.37 & 1.16 & 0.98 \\
\hline $\mathrm{C}_{8} \mathrm{H}_{16}$ & 122.6 & 0.36 & 0.11 & 1.83 & 0.53 & 1.64 & 0.54 & 1.70 & 0.42 & 1.52 & 0.56 & 2.44 & 2.00 & 1.69 & 1.42 \\
\hline $\mathrm{C}_{9} \mathrm{H}_{38}$ & 147.9 & 1.08 & 0.31 & 2.94 & 0.85 & 1.60 & 0.53 & 2.03 & 0.51 & 2.34 & 0.86 & 3.08 & 2.52 & 2.22 & 1.86 \\
\hline $\mathrm{C}_{10} \mathrm{H}_{20}$ & 171.4 & 3.53 & 1.02 & 5.25 & 1.52 & 3.19 & 1.05 & 4.00 & 1.00 & 5.14 & 1.90 & 4.52 & 3.71 & 3.56 & 2.99 \\
\hline $\mathrm{C}_{11} \mathrm{H}_{22}$ & 193.8 & 3.27 & 0.95 & 4.00 & 1.16 & 1.80 & 0.59 & 2.53 & 0.63 & 3.22 & 1.19 & 3.34 & 2.74 & 3.54 & 2.97 \\
\hline $\mathrm{C}_{11} \mathrm{H}_{24}$ & 196.1 & 0.54 & 0.16 & 1.03 & 0.30 & 0.68 & 0.22 & 0.94 & 0.24 & 1.38 & 0.51 & 1.10 & 0.90 & 1.38 & 1.16 \\
\hline $\mathrm{C}_{12} \mathrm{H}_{24}$ & 214.0 & 2.98 & 0.86 & 3.10 & 0.90 & 1.49 & 0.49 & 2.06 & 0.51 & 2.43 & 0.90 & 2.59 & 2.12 & 3.20 & 2.69 \\
\hline $\mathrm{C}_{12} \mathrm{H}_{26}$ & 216.1 & 1.05 & 0.30 & 1.10 & 0.32 & 0.73 & 0.24 & 0.99 & 0.25 & 1.43 & 0.53 & 1.10 & 0.90 & 1.55 & 1.30 \\
\hline $\mathrm{C}_{13} \mathrm{H}_{26}$ & 233.7 & 3.16 & 0.92 & 2.98 & 0.86 & 1.56 & 0.52 & 1.89 & 0.47 & 2.25 & 0.83 & 2.52 & 2.06 & 3.34 & 2.81 \\
\hline $\mathrm{C}_{13} \mathrm{H}_{28}$ & 235.9 & 1.14 & 0.33 & 1.68 & 0.49 & 1.67 & 0.55 & 1.97 & 0.49 & 2.96 & 1.09 & 1.34 & 1.10 & 1.86 & 1.56 \\
\hline $\mathrm{C}_{14} \mathrm{H}_{28}$ & 251.6 & 3.24 & 0.94 & 2.71 & 0.79 & 1.18 & 0.39 & 1.53 & 0.38 & 1.60 & 0.59 & 2.30 & 1.89 & 3.09 & 2.60 \\
\hline $\mathrm{C}_{14} \mathrm{H}_{30}$ & 253.3 & 0.63 & 0.18 & 1.13 & 0.33 & 0.72 & 0.24 & 0.82 & 0.21 & 1.14 & 0.42 & 1.11 & 0.91 & 1.55 & 1.30 \\
\hline $\mathrm{C}_{15} \mathrm{H}_{30}$ & 269.0 & 3.04 & 0.88 & 2.49 & 0.72 & 1.05 & 0.35 & 1.36 & 0.34 & 1.44 & 0.53 & 2.24 & 1.84 & 2.94 & 2.47 \\
\hline $\mathrm{C}_{13} \mathrm{H}_{32}$ & 270.6 & 0.81 & 0.24 & 1.11 & 0.32 & 0.86 & 0.28 & 1.03 & 0.26 & 1.36 & 0.50 & 1.15 & 0.94 & 1.58 & 1.32 \\
\hline $\mathrm{C}_{16} \mathrm{H}_{32}$ & 285.2 & 2.76 & 0.80 & 2.19 & 0.63 & 0.80 & 0.26 & 1.06 & 0.27 & 0.96 & 0.35 & 2.01 & 1.65 & 2.53 & 2.13 \\
\hline $\mathrm{C}_{16} \mathrm{H}_{34}$ & 286.7 & 0.82 & 0.24 & 0.97 & 0.28 & 0.66 & 0.22 & 0.71 & 0.18 & 0.95 & 0.35 & 1.26 & 1.03 & 1.65 & 1.39 \\
\hline $\mathrm{C}_{17} \mathrm{H}_{34}$ & 300.8 & 2.68 & 0.78 & 1.96 & 0.57 & 0.66 & 0.22 & 0.89 & 0.22 & 0.72 & 0.27 & 1.89 & 1.55 & 2.29 & 1.92 \\
\hline $\mathrm{C}_{17} \mathrm{H}_{36}$ & 302.2 & 0.70 & 0.20 & 0.79 & 0.23 & 0.50 & 0.17 & 0.54 & 0.14 & 0.64 & 0.24 & 1.00 & 0.82 & 1.38 & 1.16 \\
\hline $\mathrm{C}_{18} \mathrm{H}_{36}$ & 315.4 & 2.67 & 0.78 & 1.84 & 0.53 & 0.56 & 0.18 & 0.78 & 0.20 & 0.56 & 0.21 & 1.80 & 1.48 & 2.13 & 1.79 \\
\hline $\mathrm{C}_{18} \mathrm{H}_{38}$ & 316.7 & 0.67 & 0.19 & 0.76 & 0.22 & 0.54 & 0.18 & 0.54 & 0.13 & 0.60 & 0.22 & 0.94 & 0.77 & 1.25 & 1.05 \\
\hline $\mathrm{C}_{19} \mathrm{H}_{38}$ & 329.4 & 2.54 & 0.74 & 1.68 & 0.49 & 0.47 & 0.15 & 0.75 & 0.19 & 0.56 & 0.21 & 1.73 & 1.42 & 2.07 & 1.74 \\
\hline $\mathrm{C}_{99} \mathrm{H}_{40}$ & 330.6 & 0.71 & 0.21 & 0.74 & 0.21 & 0.54 & 0.18 & 0.51 & 0.13 & 0.55 & 0.20 & 0.95 & 0.78 & 1.26 & 1.06 \\
\hline $\mathrm{C}_{20} \mathrm{H}_{40}$ & 342.8 & 2.17 & 0.63 & 1.35 & 0.39 & 0.34 & 0.11 & 0.55 & 0.14 & 0.30 & 0.11 & 1.44 & 1.18 & 1.71 & 1.44 \\
\hline $\mathrm{C}_{20} \mathrm{H}_{42}$ & 343.9 & 0.79 & 0.23 & 0.78 & 0.23 & 0.62 & 0.20 & 0.59 & 0.15 & 0.67 & 0.25 & 0.97 & 0.79 & 1.24 & 1.04 \\
\hline $\mathrm{C}_{21} \mathrm{H}_{42}$ & 355.8 & 1.93 & 0.56 & 1.22 & 0.35 & 0.31 & 0.10 & 0.49 & 0.12 & 0.25 & 0.09 & 1.34 & 1.10 & 1.56 & 1.31 \\
\hline $\mathrm{C}_{21} \mathrm{H}_{4}$ & 356.8 & 0.55 & 0.16 & 0.57 & 0.16 & 0.31 & 0.10 & 0.36 & 0.09 & 0.28 & 0.10 & 0.80 & 0.65 & 1.10 & 0.92 \\
\hline $\mathrm{C}_{22} \mathrm{H}_{44}$ & 368.0 & 1.70 & 0.49 & 1.01 & 0.29 & 0.20 & 0.07 & 0.39 & 0.10 & 0.15 & 0.06 & 1.19 & 0.97 & 1.36 & 1.14 \\
\hline $\mathrm{C}_{22} \mathrm{H}_{46}$ & 368.9 & 0.52 & 0.15 & 0.55 & 0.16 & 0.49 & 0.16 & 0.41 & 0.10 & 0.32 & 0.12 & 0.80 & 0.66 & 1.05 & 0.88 \\
\hline $\mathrm{C}_{23} \mathrm{H}_{46}$ & 379.2 & 1.46 & 0.42 & 0.86 & 0.25 & 0.18 & 0.06 & 0.33 & 0.08 & 0.19 & 0.07 & 1.05 & 0.86 & 1.23 & 1.03 \\
\hline $\mathrm{C}_{23} \mathrm{H}_{46}$ & 380.0 & 0.54 & 0.16 & 0.50 & 0.15 & 0.49 & 0.16 & 0.40 & 0.10 & 0.34 & 0.12 & 0.71 & 0.59 & 1.02 & 0.86 \\
\hline $\mathrm{C}_{24} \mathrm{H}_{48}$ & 390.3 & 1.24 & 0.36 & 0.72 & 0.21 & 0.12 & 0.04 & 0.27 & 0.07 & NI & 0.00 & 0.87 & 0.72 & 1.00 & 0.84 \\
\hline $\mathrm{C}_{24} \mathrm{H}_{50}$ & 391.1 & 0.42 & 0.12 & 0.49 & 0.14 & 0.46 & 0.15 & 0.39 & 0.10 & 0.32 & 0.12 & 0.67 & 0.55 & 0.87 & 0.73 \\
\hline Totals & & 49.96 & 14.49 & 52.19 & 15.14 & 30.64 & 10.11 & 35.50 & 8.87 & 38.05 & 14.08 & 53.38 & 43.77 & 60.42 & 50.75 \\
\hline
\end{tabular}


APPENDIX A

SOLVENT DISSOLUTION ANALYSIS METHOD 
November 12, 1992

Amoco Chemical Company

Research and Development Deparment

Post Office Box 3011

Naberville. " $60566-701 ?$

$708-420-5111$

Mr. B. Bryant STimp, Jr.

Lyondell Petrochemical Company

One Houston Center, Suite 1600

1221 McKinney Street

Houston, TX 77253-3646

Dear Bryant:

Attached to this letter is a copy of the analytical method that we developed at Amoco to analyze waste plastic samples in order to determine the types and amounts of plastics present and the associated organic and inorganic impurities. I've also attached some recent analyses in order to give you an idea of the capability of the method.

We developed this method with the intent of getting as much data as possible using classical analytical procedures. These include weighing, dissolving, precipitating, drying and reweighing. The only instrumental techniques involved are $x$-ray fluorescence (XRF) and inductively coupled plasma (ICP) spectroscopy for the metals and non-metals determination.

We have received samples in two different forms; one is from a curbside pickup program and the other is from recycling companies. The former were plastic garbage bags of intact plastic containers or other packaging material. In this case we first did an inventory of the bag contents by weight and type (see Tables I and II); then we reduced the entire sample by cutting and grinding to a uniform particle size from which we could remove a reasonably homogeneous sample (visual criteria) for analysis. The samples from commercial recyclers were already ground up and homogenized so getting a reasonably homogeneous sample was the main analysis issue.

The method was tested using a known polymer mixture and the data are shown in Table III. Table IV shows the results from six repeat analysis of a sample of plastics waste from a recycler in New Jersey. Table $V$ shows data on five bags of plastic waste from the Chicago recycling pick up proyram. Table VI shows an analysis for metals and non-metals.

We can discuss the method further at our next Tertiary Recycling Committee, Feedstock Definition Team meeting. Please send this report and attachments to the other team members as you see fit.

Sincerely,

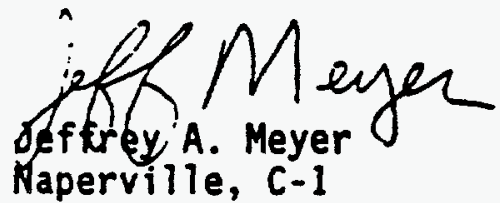

JAM/djd

Attachments 


\section{ANALYTTCAL METHOD FOR POLFMER WASTE STREAYS}

\section{Scope}

This method will quancieacively and quaiticatively amalyze a poiymer vaste srzean for polymers, weeals, and nonmerals. The method involites using XRF, ICR, and FIIR spectzoscopy along ri th a solvenc separacion secinique.

\section{Suryer}

Municipal and industrial polymer waste, is the form of cujb-side pick-up or rasied and chopped chips, can be sampied and analyzed by chis meetod. Te sample siould be of a represencacive size, which can be $\$=0$ m $500 \mathrm{~g}$. For an industzial sample, to I5 kilograms of municipal curj-side poijmez rasce. The sample is zeducad to parzicies approximateily $1 \mathrm{~cm} \times 1$ ca by sawing, chopping, and grinding, if neeced. Analyses by RR, ICZ, ard T:ZR are pefforzed on the bulk sample. The sample is exs=acsed rist rater and XCF and ICZ analyses are complered on the extzacs. The particles f=om the wase ex=sact are dried, and a solvenc(0-xylene) separacion inco polymes r.pes is performed. ICR, XRF, and $F: Z$ analyses are compieted on sie six Eackions and the weighes are obeained after dfying. All zesulis a:s reporsed in a scandard formar. If there is a parjicular couponent in ite sampie of interest then the analysis can be cistomized to accomoda analysis for that particiliar component. A Elow char and sample repor forma: are included in ehis mechod Eor zeference purposes (Iigures 2 and 3).

\section{Apparafes}

- 1 Temperacure Coneroller

- 2 Thermomecers $0 \cdot 200^{\circ} \mathrm{C}$

- 3 Condensers

- 3 Resir kecieles (4 neck)

- I Stizzing Mocor

- I Shafe and Blade for above

- I Glass Joine (waeer cooled) for Sei=zer

- Beakers (600 ml)

- Vials and Jars (Several sizes for Ẽactions)

- XRF. ICR, and FTIR Aralysis Available

- Screer 40 to 60 Mesh

- 0-xylere (998 Eascoman-Kodak)

\section{Samole Prep}

Select a representative sample by detemining the type of waste sizes.a. municipal/induscrial, large/small pieces, few/many polymer eypes. The largez the variecy of polymer cypes expected in the stzean, the lazjo: zie 
sample should be. For example, a municipal post consumer polymer waste stream may aced 15 to $18 \mathrm{ktlog} a m s$ sampled, and a manufacsugting waste seream may need 500 grams. Once the sample is selected. Is should be Inventorled. Ints is done by liselag the contents, weighing each plece, and recording the polymer egpe if possible. The imentory process should be done using proper saferf precautions such as gloves, hood, and if accessafy face mask and rubber apron. Caufion mise be used due to the possibilify of broken glass, chemical, and biological hazards present in the sample. Sample preparaton vill vary according to the size of the pieces and gpe of polymers in the sample. The goal is to obezin a representactre sample chipped inco pleces about $I \mathrm{~cm} x I \mathrm{~cm}$ in area and a ebickenss of $20 \mathrm{mils}$ to $\mathrm{l}$ an. However, this is not alvays possible. Sampies of conealners muse be sared ineo serips using a band saw and the stzips ground using a rotating blade mill. The result is pieces of various sizes with most being $0.25 \mathrm{~cm} \times 0.50 \mathrm{~cm}$. If pieces of sample are too small' (such as powders), they will be drawn ineo the sample flask, through the screen and separation will not be achieved. Once the sampie is ground, mix the particles by shaking them in a large piastic bag.

\section{Compositis Sample}

Once the bulk sample $(500 \mathrm{~g}-18 \mathrm{~kg}$.$) is ground and mixed, 100 \mathrm{~g}$ is collec=ed and reduced to powder. This is accomplished by cooling the sample with liquid nierogen and passing it through a Brinloman grinder using a 1.5 pore size sezeen. This powder is then analyzed for the followiag elements by XRF and ICR analyses: Cl, P, Za, S, Kr, Si, Pb, CE, Fe, Ni, Ci, Co, Na, K. Ca. Al. I1. Sb. The powder is also sent for ash oxide analysis.

\section{Water Hash}

Take $100 \mathrm{~g}$ of the ground and mixed sample and place $i=$ in a 2 lizez jaz. Add $250 \mathrm{ml}$ of disfilled wacer and shake vigorously for 3 minues. Afier shaking. pass liquid through a very coarse filcer or fine scieen and obcain IC? analysis of the extract for the following metals and nonmetals: Cl, 2a, Ma, Fe, Cu, Ma, K, Ca, Al, I1. Oven dry che solids ar $110^{\circ} \mathrm{C}$. under vacuum, with a nitrogen purge. These chips will be used for st.e solvene dissolueion analysis.

\section{Solvenc Dissolueion}

Refer to Flgure I for the equipment setup. The first part of the apparacus labeled "Dissolution Assembly" consists of a 500 ol resin kes=ie equipped with a water cooled condenser and lab stirzer. The kerele is placed in a hearing wanele, which in turn is connecsed to a Eurotherz cemperature controller with over-remperacure protection. An addisiona! chersocouple connecred to a digital display is Immersed in the solventoxylene) to monicor the temperature. The separace fractions of the mixed plastic waste are dissolved in this resin ketrle. The second portion oz the apparatus in Figure 1 is the "Filezacion Assembly." Is consisis of a filis=3rion and transfer tube conneceed to a vacuum flask, which in tu=n is consected to a vacuum source. The third portion of the apparacus in 
Flgute 1 is a set of tro resin ketsles used to heat the wash solvent so the same remperature as the dissolution ketsle, and to heat the nex= porston of solvent to the next higher temperacure for dissolurfon.

1. After the chlps Erom the water wash aro drg, place 20 co 25 grams of them into the resin ketrle marked " $C$ ".

2. Add $500 \mathrm{ml}$ of $0-x \mathrm{gleae}$ and $s 5 i=$ for 30 minuses ar $25^{\circ} \mathrm{C}$. Also add $500 \mathrm{al}$ of $0-x y l e n e$ to each of the other tso resia ketsles and brisg each to cemperasure.

3. Draw off the o-xylene by applytag a vacurn to tie sample Elasic.

4. Iransfer this solution 50 a teared $600 \mathrm{ml}$ beaker.

5. Transfer " 500 ml of solvent from zesin ketsle marked " 3 " which is set to the same temperature as sesia ketsie " $\mathrm{Cn}$.

6. Mix 30 seconds and transfer to a sared 600 al beakez.

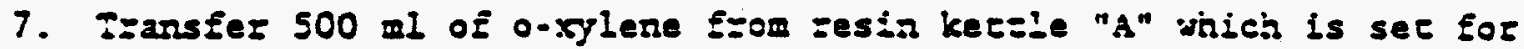
the nexe higher cemperacure fraciion. This avoids raising for remperature lacreases fzom zoom iemperacure. Hear 30 ainutes and repeas procedure from 3 througi 7 for each tenperature fracion $\left(25^{\circ} \mathrm{C}, 75^{\circ} \mathrm{C}, 105^{\circ} \mathrm{C}, 120^{\circ} \mathrm{C}, 138^{\circ} \mathrm{C}\right)$.

NOTE: Replenish che o-xylene in eaci ketsle as soon as is is being used. Inis will minimize the cime needed co reach zemperatire.

8. When the last cemperacure fun is complece, collect the zesidie in resir ketrle " $C$ " as the insoluble.

9. Take the beakers to drgness on a sream bach with rizsogen blowing ovez chem.

10. Weigh The fractlons and obcain XRF, ICR and FIIR analyses. (:CR and

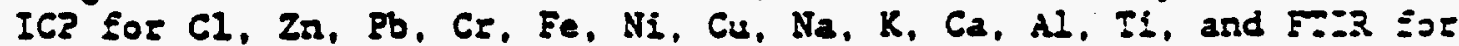
polymer idencification)

11. Assemble all data lneo a report format such as the example provided (See atrached report form). II chis is done using a word processo:. the form car easily be altered to accept the larger area needed Eor ceresin pares of repore such as "invencory".

\section{Nores}

To atzain the necessary skill at running this apparatus and setiang siee remperatures corzectly, one should prepare and analyze a known blend oz polymers. 


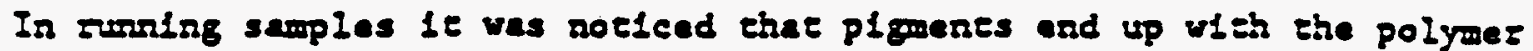
fracsion they were orfginelly assoclaced with. Some addistves will be leached fnto earlfer fractions along with plastictzers. 


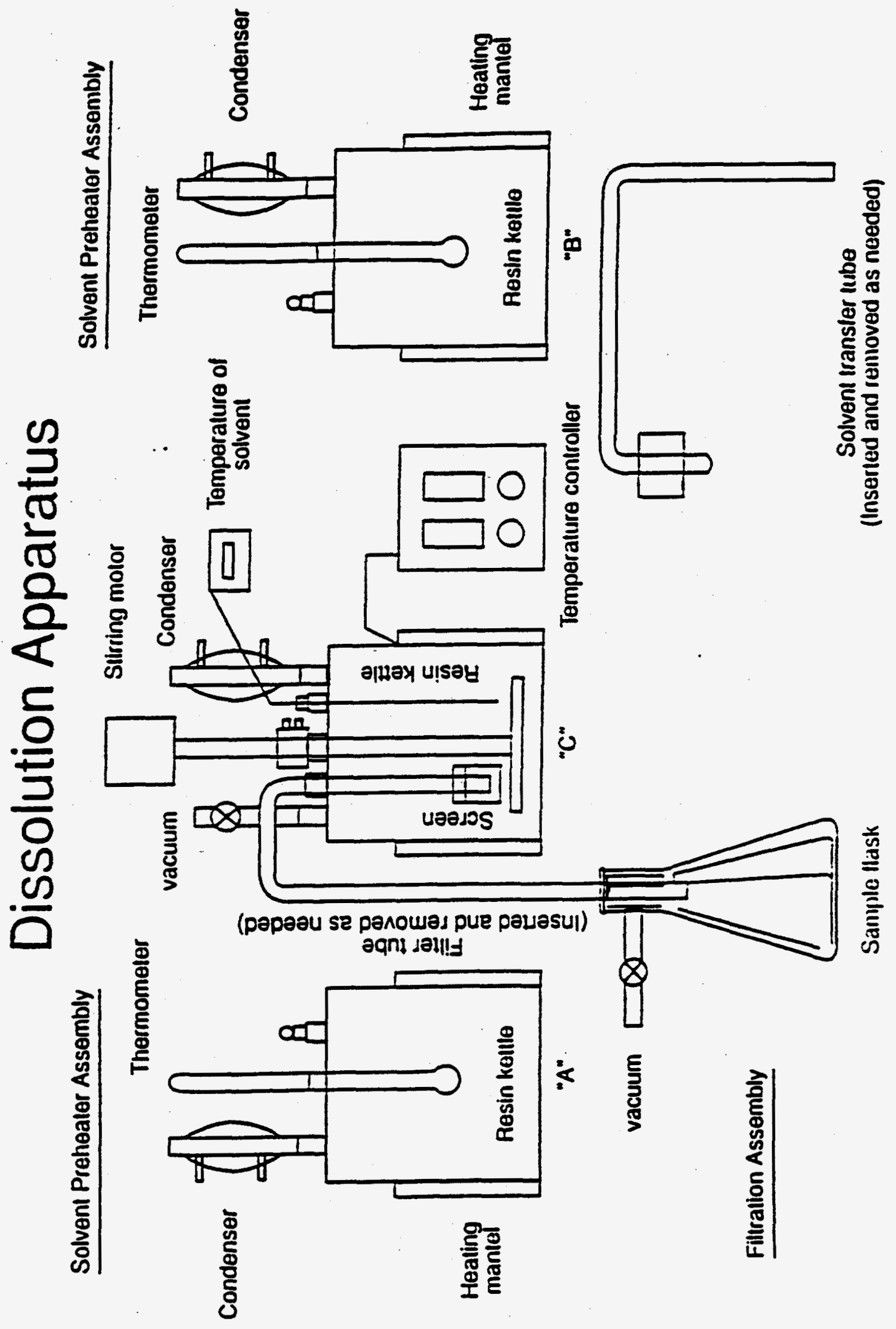

Eigure 1. 


\section{POLYMER NASTE ANALYSIS ELOW CHARE}

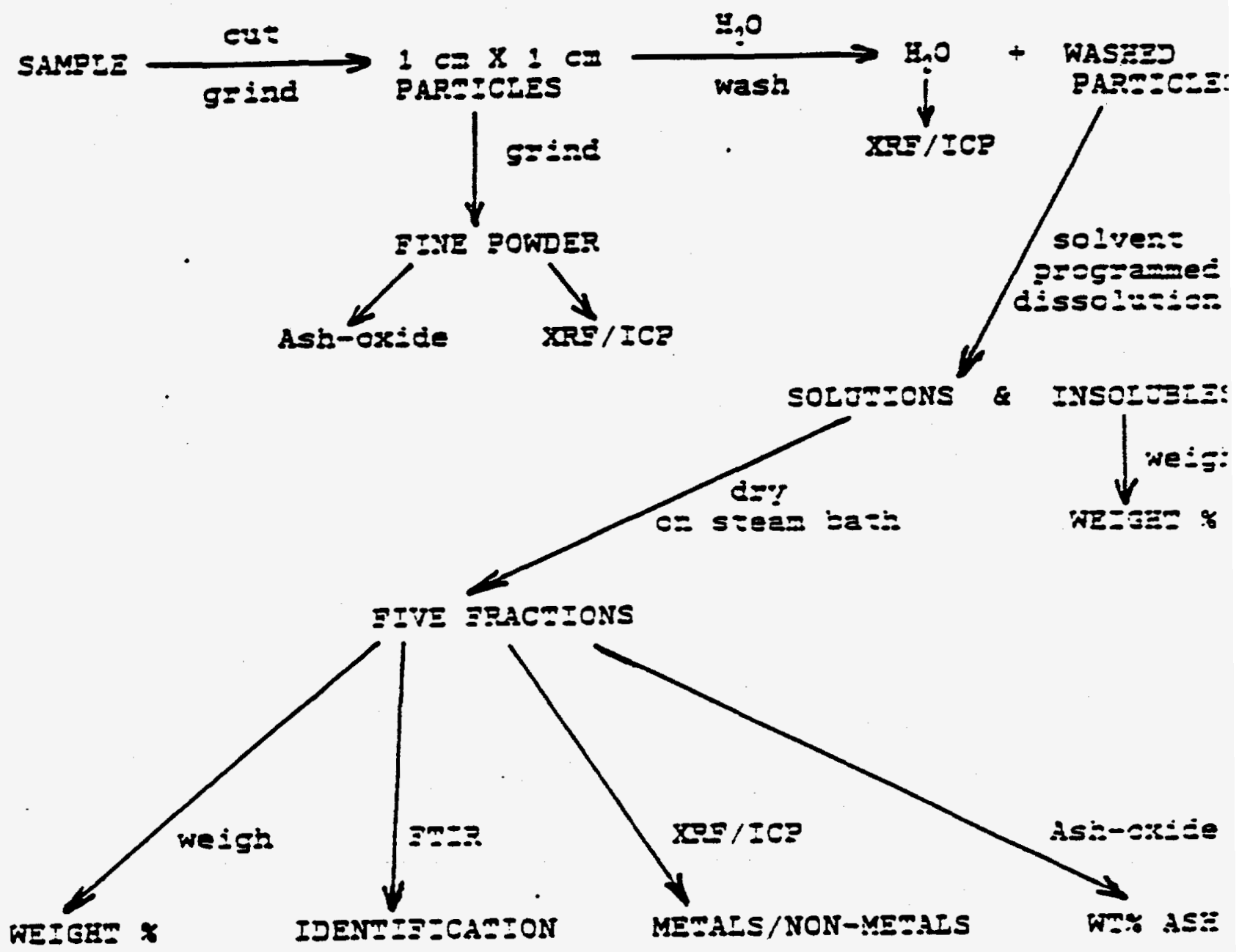

Eicuse 2. 


\section{BOLYMER HASTE MNALYSIS REPOR:}

Cliene:

SAMPLE:

Discription/Inventors:
CARV:

DADS:

Water Mash:

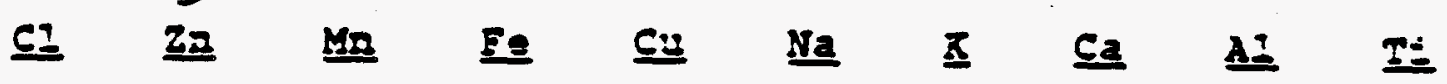

Composite:

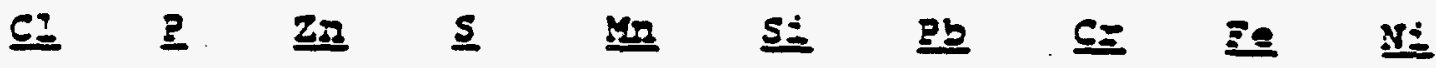

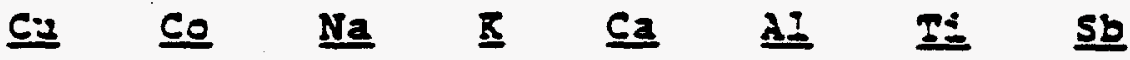

Asin-oxide $=$

Dissoiution Resules:

PS

$\underline{(25 C)}$
LOPE

$(75 C)$
gDps

$\underline{(105 C)}$

\section{EP}

(120C)
PVC

$1 \pm 38 C)$
Residue

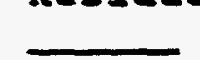

Eienereal Analtais of Fractions:

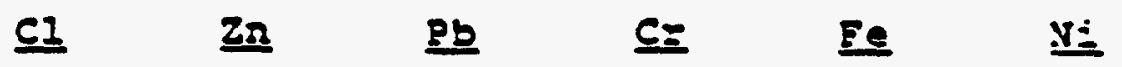

Eraction PS

Fraction LDPE

Eraction HDPE

Eraction PP

Fraction pUC

Eigure 3. 
Praction Residue

므 스

ca

II

$\underline{I i}$

Frac::00 PS

Iraction LDPE

Fraction HPS

Exact:on po

Iraction EVC

Eracsion Residue

E:-R 3esuites:

IYac:ion RS:

SZaCEiOR LDEE:

ZZACSEOR HDFE:

Ezaction pㅁ:

ZZaC:EOR PVC:

I=acsior Residue:

Comments:

47 
कृ

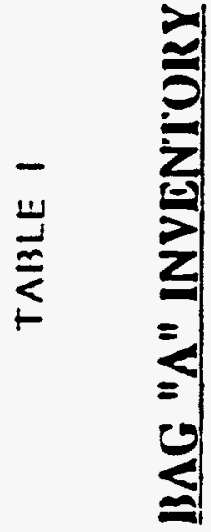

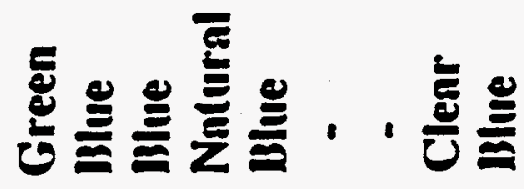

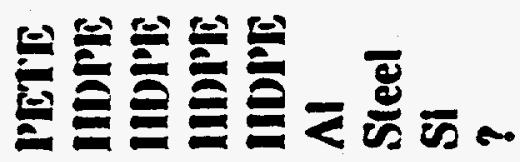

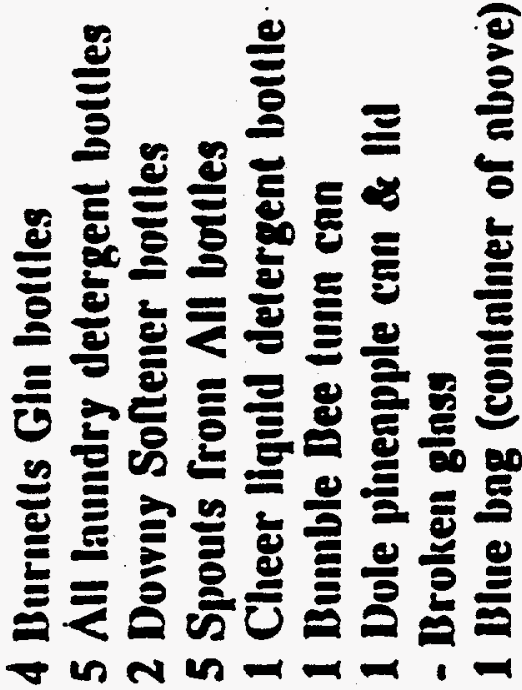




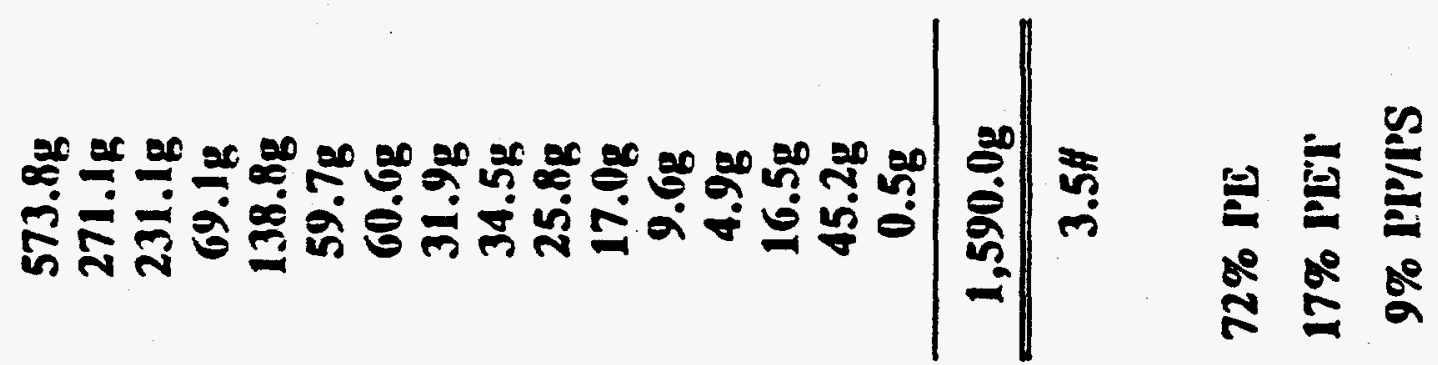
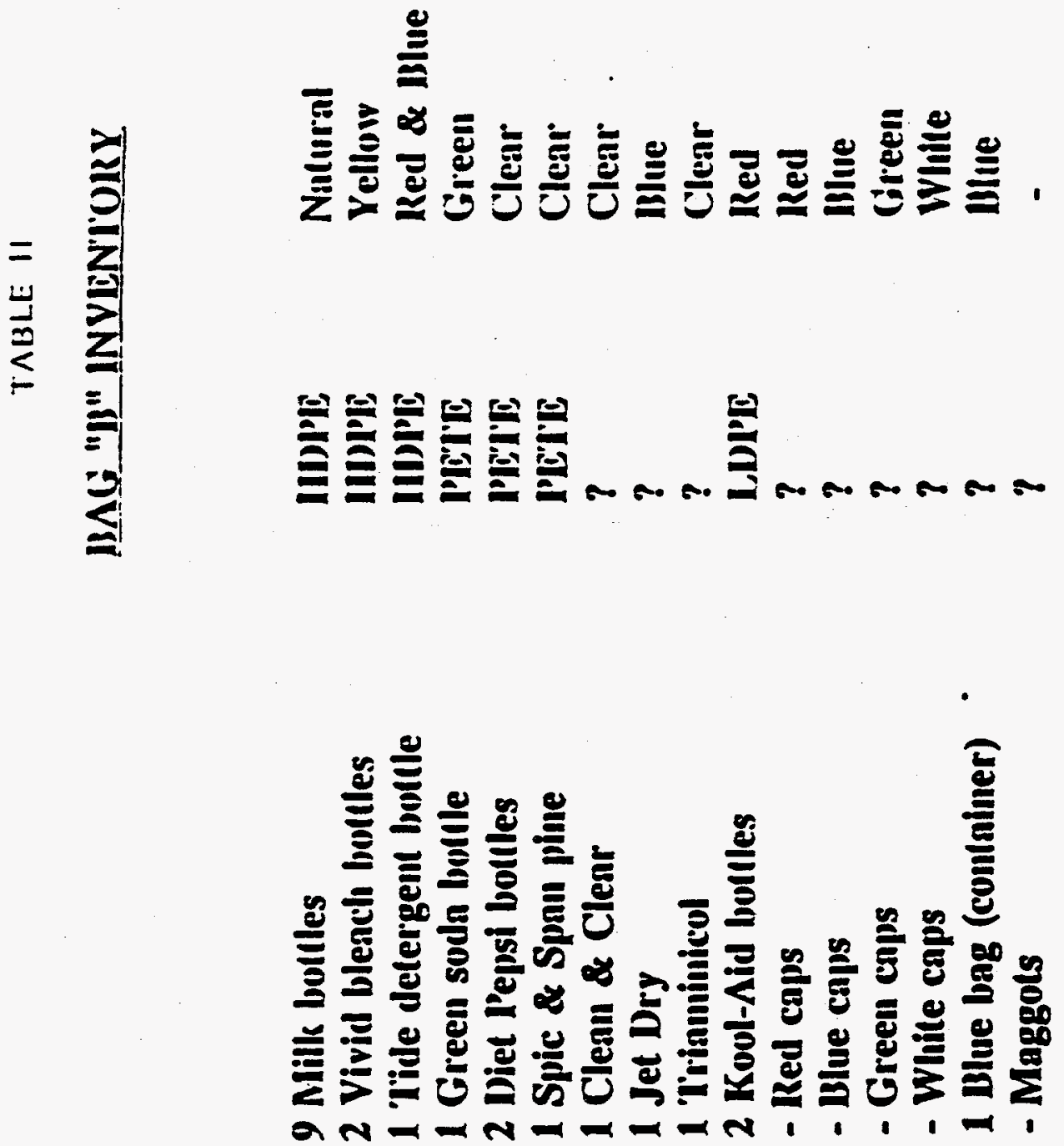
TABLE III

\section{Solvente Separacion Resules}

Polymer

35

LDPE

EDPE

29

PVC

PEI

\section{Known Blend}

4.76

9.46

70.5

4.77

0.99

9.55

1008
Found

4.6

1.3

80.6

3.8

0.6

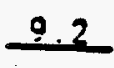
100
Ienperacure ic

25

75

105

120

138

Residue 


\section{Polymer Vaste Analysts}

\section{New Jersey Tailines}

\section{Componene}

PS.

LDPE

HDPE

PP

PVC

Residue
Weighe: 16 Analyses)

$$
0.85 \pm 0.18
$$

$2.1 \pm 0.6$

$91.2 \pm 2.3$

$5.5 \pm 2.1$

$0.18 \pm 0.07$

$0.42 \pm 0.11$
Ranse

$0.65 \cdot 1.2$

$1.4-2.8$

$87.3^{\circ} \cdot 94.5$

$2.5 \cdot 8.7$

$0.10 \cdot 0.27$

$0.26 \cdot 0.51$ 
TABLE V

Vissolution Results in wt.f

\begin{tabular}{|c|c|c|c|c|c|c|c|}
\hline Sample & $\begin{array}{l}\text { PS } \\
\left(25^{\circ} \mathrm{C}\right)\end{array}$ & $\begin{array}{l}\text { LDPE } \\
\left(75^{\circ} \mathrm{C}\right)\end{array}$ & $\begin{array}{l}\text { IIDPE } \\
\left.1105^{\circ} \mathrm{C}\right)\end{array}$ & $\begin{array}{l}\text { PP } \\
\left(120^{\circ} \mathrm{C}\right)\end{array}$ & $\begin{array}{l}\text { PVC } \\
\left(138^{\circ} \mathrm{C}\right)\end{array}$ & Resldue & 1 Ash \\
\hline New Jersey $8-20-91$ & 0.88 & 1.9 & 89.6 & 7.1 & 0.10 & 0.44 & 1.1 \\
\hline $\begin{array}{l}\text { Chlcago Recyclling Works } \\
\text { Bag "A" } \\
\text { Bag "B" } \\
\text { Bag "C" } \\
\text { Bag "D" } \\
\text { Bag "E" }\end{array}$ & $\begin{array}{c}0.75 \\
2.5 \\
3.3 \\
18.9 \\
20.8\end{array}$ & $\begin{array}{l}1.0 \\
1.9 \\
2.8 \\
8.1 \\
6.4\end{array}$ & $\begin{array}{l}73.0 \\
75.8 \\
92.2 \\
46.7 \\
47.7\end{array}$ & $\begin{array}{c}0.28 \\
1.3 \\
0.43 \\
15.7 \\
15.5\end{array}$ & $\begin{array}{l}0.12 \\
0.08 \\
0.14 \\
1.6 \\
2.4\end{array}$ & $\begin{array}{r}24.9 \\
18.4 \\
1.2 \\
9.0 \\
7.1\end{array}$ & $\begin{array}{l}1.3 . \\
1.1 \\
2.5 \\
2.5 \\
1.2\end{array}$ \\
\hline $\begin{array}{l}\text { North American Plastlcs } \\
\text { Recycling Corp. }\end{array}$ & 8.7 & 9.8 & 55.5 & 16.6 & 3.2 & 6.22 & 1.6 \\
\hline
\end{tabular}


TABLE VI

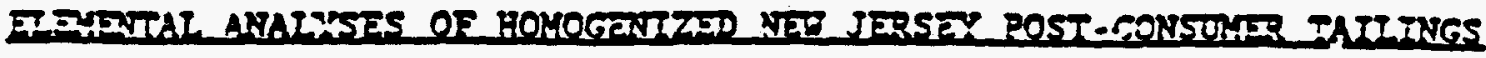

ICZ BESULS (Coxcantraesons in ppos):

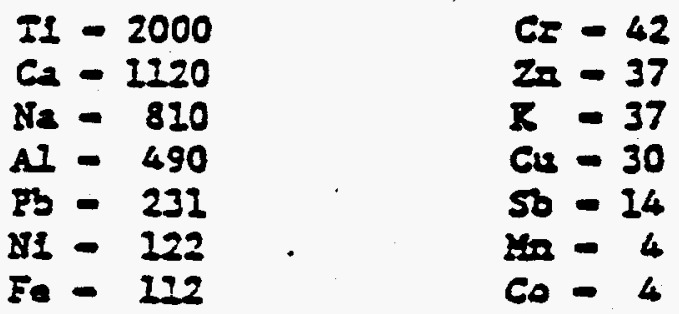

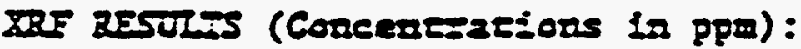

lase Anaivets

\begin{tabular}{|c|c|}
\hline $\begin{array}{l}C_{L}=25100= \\
S 1=1450 \\
I 1=1250 \\
C_{1}=1120 \\
S=590\end{array}$ & $\begin{array}{l}P=275 \\
z=-40 \\
C E=30 \\
Z z=12 \\
M 1=-2\end{array}$ \\
\hline
\end{tabular}

Rereae Ansiosis

\begin{tabular}{ll}
\hline$C I-22700$ & $z=233$ \\
$S I=1240$ & $F E=39$ \\
$I I-1320$ & $C E=30$ \\
$C_{2}=790$ & $Z 2=<5$ \\
$S-500$ & $N 1=<2$
\end{tabular}

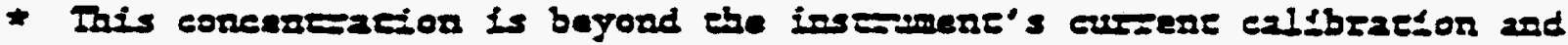
iberefora camoc be considared as acsurace. The acseri CI coscenezfor may be somewial diffareat. 
APPENDIX B

ANALYTICAL PROCEDURES 



\section{SIMULATED DISTILLATION METHODS}

The "Retention Time," "Area \%," "Yield \%," "wt\%," and "Cumulative Area \%" values in Table D-1 (using M290 as an example) were obtained directly from the gas chromatography/flame ionization detection (GC/FID) analysis of the sample. The "Boiling Point Index" and "Retention Index" values were calculated from the GC/FID analysis of an alkane standard, which comprises the series of 26 normal alkanes from $\mathbf{C}_{5}$ (pentane) to $\mathrm{C}_{30}$. Boiling points for several of the alkanes are listed in Table D-2. The simulated distillation technique employed for this work uses the boiling points and retention indices (arbitrarily assigned values such that $C_{5}$ has a retention index (RI) of 500, $C_{6}$ has an $R I$ of $600, \mathrm{C}_{10}$ has an $\mathrm{RI}$ of 1000 , etc.) of the normal alkanes to relate component GC retention time to boiling point and RI. For example, if a compound has a retention time halfway between the retention times of pentane and hexane, the compound will be assigned a boiling point index of $52.5^{\circ} \mathrm{C}$ (halfway between $36^{\circ}$ and $69^{\circ} \mathrm{C}$, the boiling points of pentane and hexane, respectively) and an RI of 550 (halfway between 500 and 600, the retention indices of pentane and hexane, respectively).

At least one GC analysis of the alkane standard is performed for every series of sample analyses. If more than eight samples are analyzed, one alkane standard analysis is performed for every eight sample analyses. Each individual alkane in the alkane standard is used as a marker to relate GC retention time to boiling point and retention index. Once this relationship is determined, the GC area count data for each sample is normalized to area percent data, which can then be plotted as a distillation profile showing cumulative percent distilled as a function of temperature, or as a bar graph showing the percentages of sample distillable in 20-degree (or other desired) increments.

Since the simulated distillation technique uses a series of normal alkanes to derive a relationship between GC retention time and boiling point, it will necessarily work best in analyzing samples composed of components similar in chromatographic behavior to alkanes. If a sample contains components that differ in chromatographic behavior from alkanes, the simulated distillation data for the sample may differ somewhat from actual distillation data, depending on the extent of the chromatographic difference. This is shown by the calculated boiling point index of styrene, an aromatic, in Table D-2. While the actual boiling point of styrene is $145.2^{\circ} \mathrm{C}$, its calculated boiling point index is about $148.0^{\circ} \mathrm{C}$, a difference of about $1.9 \%$. Most of the detected compounds were not identified, since most were present in very small quantities.

In Table D-1, each yield value is calculated as the area \% detected for the entire sample times the total liquid yield. Because of this, and because the tables include area \% data for only GC/MS-identified compounds, the sum of the area \% values at a given retention time will not equal the corresponding cumulative area \% value.

Since the GC/FID analysis used in this work provides area count data for every detected component in a sample, the simulated distillation data discussed above are only a portion of the data obtainable using the GC/FID analysis of a plastics decomposition liquid. For more detailed information, component identification templates (for component identification and quantitation in similar liquids) can be produced using GC/MS, GC/AED, and GC coupled with FT-IR analysis. Use of a component identification template enables

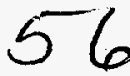


the merging of sample analyses together (on the basis of retention time, boiling point index, or retention index) into a database for comparison of different samples and/or tracking changes in individual component concentrations and overall sample composition due to processing condition changes.

TABLE D-1

Polypropylene/Polystyrene $\mathrm{GC}$ Analysis at $525^{\circ} \mathrm{C}$ in $\mathrm{CaCO}_{3}(\mathrm{M} 290)-\mathrm{CH}_{2} \mathrm{Cl}_{2}$ Injection

\begin{tabular}{|c|c|c|c|c|c|c|}
\hline $\begin{array}{l}\text { Boiling Point } \\
\text { Index, }{ }^{\circ} \mathrm{C}\end{array}$ & $\begin{array}{l}\text { Retention } \\
\text { Time } \\
\text { Index }\end{array}$ & $\begin{array}{l}\text { Retention } \\
\text { Time, min }\end{array}$ & $\begin{array}{c}\text { Area } \\
\%\end{array}$ & $\begin{array}{c}\text { Cumulative } \\
\text { Area \% }\end{array}$ & $\begin{array}{l}\text { Yield, } \\
\text { wt\% }\end{array}$ & $\begin{array}{l}\text { Compound } \\
\text { Identification }\end{array}$ \\
\hline 120.92 & 781.28 & 0.95 & 3.25 & 3.82 & 3.06 & Toluene \\
\hline 132.98 & 829.51 & 1.45 & 6.00 & 10.59 & 5.64 & $\mathrm{C}_{9} \mathrm{H}_{18}\left(\mathrm{C}_{9}\right.$ olefin $)$ \\
\hline 137.06 & 845.85 & 1.62 & 0.71 & 11.64 & 0.67 & $\mathrm{C}_{2}$ Benzene \\
\hline 147.97 & 889.49 & 2.08 & 52.80 & 65.36 & 49.63 & Styrene \\
\hline 166.68 & 969.03 & 3.93 & 2.53 & 68.53 & 2.38 & $C_{1}$ Styrene \\
\hline 185.46 & 1052.05 & 6.11 & 0.30 & 70.20 & 0.28 & $\mathrm{C}_{2}$ Styrene \\
\hline 191.15 & 1077.72 & 6.79 & 0.78 & 71.10 & 0.73 & $\mathrm{C}_{12} \mathrm{H}_{24}$ \\
\hline 192.04 & 1081.72 & 6.90 & 0.59 & 71.70 & 0.55 & $\mathrm{C}_{12} \mathrm{H}_{24}$ \\
\hline 202.32 & 1131.09 & 8.06 & 0.96 & 72.94 & 0.90 & $\mathrm{C}_{5} \mathrm{H}_{10}+$ Benzene \\
\hline 202.98 & 1134.41 & 8.14 & 0.56 & 73.50 & 0.53 & $\mathrm{C}_{5} \mathrm{H}_{10}+$ Benzene \\
\hline 232.30 & 1283.07 & 11.13 & 0.35 & 75.50 & 0.33 & $\mathrm{C}_{14} \mathrm{H}_{28}$ \\
\hline 236.01 & 1302.32 & 11.49 & 1.25 & 76.84 & 1.18 & $\mathrm{C}_{15} \mathrm{H}_{30}$ \\
\hline 237.53 & 1310.92 & 11.63 & 1.51 & 78.35 & 1.42 & $\mathrm{MW}_{\text {Benzene? }}=17 \mathrm{C}_{7}$ \\
\hline 238.98 & 1319.11 & 11.77 & 1.00 & 79.36 & 0.94 & $\mathrm{C}_{25} \mathrm{H}_{30}$ \\
\hline 246.55 & 1361.85 & 12.51 & 0.66 & 80.24 & 0.62 & $\mathrm{C}_{8}$ Benzene \\
\hline 270.92 & 1501.99 & 14.80 & 1.05 & 82.24 & 0.99 & Diphenylethane \\
\hline 273.68 & 1519.11 & 15.06 & 0.38 & 82.74 & 0.36 & $\mathrm{C}_{28} \mathrm{H}_{36}$ \\
\hline 276.32 & 1535.50 & 15.30 & 0.61 & 83.51 & 0.57 & $\mathrm{C}_{1}$ Diphenylethane \\
\hline 292.07 & 1634.66 & 16.77 & 0.71 & 85.51 & 0.67 & Diphenylpropane \\
\hline 302.98 & 1705.40 & 17.77 & 4.84 & 90.89 & 4.55 & Styrene Dimer \\
\hline 304.76 & 1717.63 & 17.94 & 0.37 & 91.41 & 0.35 & Diphenylpropene \\
\hline 311.47 & 1763.91 & 18.54 & 0.47 & 92.36 & 0.44 & $\mathrm{C}_{21} \mathrm{H}_{42}$ \\
\hline 327.23 & 1875.75 & 20.03 & 0.52 & 94.02 & 0.49 & $\mathrm{MW}=234$ \\
\hline 336.21 & 1942.15 & 20.88 & 0.07 & 94.35 & 0.07 & $M W=204$ \\
\hline 338.85 & 1962.06 & 21.12 & 0.26 & 94.65 & 0.24 & $\mathrm{MW}=220$ \\
\hline 346.24 & 2018.24 & 21.81 & 0.25 & 95.12 & 0.24 & $\mathrm{MW}=220$ \\
\hline
\end{tabular}


TABLE D-2

Normal Alkane Boiling Points

\begin{tabular}{cc}
\hline -Alkane Carbon Number & Boiling Point, ${ }^{\circ} \mathrm{C}$ \\
\hline 5 & 36 \\
6 & 69 \\
7 & 98 \\
8 & 126 \\
9 & 151 \\
10 & 174 \\
11 & 196 \\
12 & 216 \\
13 & 235 \\
14 & 253 \\
15 & 271 \\
20 & 344 \\
25 & 402 \\
30 & 450 \\
\hline
\end{tabular}


- Organic and Chlorine Determination (GC- AED) 


\section{TOTAL AND ORGANIC CHLORINE DETERMINATION}

To determine chlorine distribution, total chlorine and organic chlorine are determined by analyses, while inorganic chlorine is calculated by their difference.

\section{Total Chlorine Content of Liquid Products}

The method used in product liquid total chlorine determination is based on ASTM Method D808-91, "Standard Test Method for Chlorine in New and Used Petroleum Products (Bomb Method)." The primary difference between the method used and ASTM D808-91 is that the ASTM method utilizes precipitation of chloride from solution for chloride quantitation. Chloride quantitation by ion chromatography is less labor-intensive and provides accurate, reproducible results. Total chlorine is determined as follows: An approximate 0.5-g sample is obtained for combustion in a Parr bomb apparatus. The weighed sample is sealed in the bomb along with a solution of $\mathrm{Na}_{2} \mathrm{CO}_{3}$ and $\mathrm{NaHCO}_{3}$, and the bomb is pressurized with oxygen to 28 atmospheres. The sample is then ignited electronically with a platinum firing wire and combusted. After a cooldown period for condensation of vapors, the bomb is opened, and the sample is removed for chloride analysis by ion chromatography.

Table B-1 is a list of several other ASTM chlorine analysis methods. After review of these methods, ASTM Method D808-91 was deemed most appropriate for these samples.

\section{Total Chlorine Content of Solid Products}

Total chlorine determination of solids ( $\mathrm{CaO}$ filter sorbent) was determined by first washing the sorbent with acid to remove chlorine. Chlorine is then quantified with ion

\section{TABLE B-1}

ASTM Chlorine/Chloride Analysis Methods

D 2384-83 Standard Test Methods for Traces of Volatile Chlorides in Butane-Butene Mixtures

E 776-87 Standard Test Method for Forms of Chlorine in Refuse-Derived Fuel

E442.91 Standard Test Method for Chlorine/Bromine/lodine in Organic Compounds, by Oxygen Flask Combustion

E256-91 Standard Test Method for Chlorine in Organic Compounds, by Sodium Peroxide Bomb Ignition

D1726 Standard Test Method for Hydrolyzable Chlorine Content of Liquid Epoxy Resins

D1847 Standard Test Method for Total Chlorine Content of Liquid Epoxy Resins 
chromatography. Chlorine-containing salts, such as calcium chloride, sodium chloride, and potassium chloride, are easily solubilized in water. Quantitation of chlorine in samples of the calcium oxide sorbent used to capture chlorine generated during the decomposition of PVC was performed as follows:

- Weigh out about $1 \mathrm{~g}$ of sample into a $100-\mathrm{mL}$ volumetric flask.

- Fill the flask to the 100 -mL line with distilled, deionized water.

- Sonicate at room temperature for about 30 minutes.

- Gently swirl, then filter, the mixture.

- Analyze the filtered liquid for total chlorine content using ion chromatography.

- If the chlorine content of the liquid is above the accurate detection level of the instrument, repeat Steps 1-5 using about $100 \mathrm{mg}$ of sample.

\section{Organic Chlorine Content of Liquid Products}

Organic chlorine concentrations were determined using gas chromatography/atomic emission detection (GC/AED) analysis. GC/AED can identify and quantitate chloride in compounds as they elute from a GC column. When a compound leaves the GC column and enters the atomic emission detector, electrons in the atoms that make up the compound are energized by a microwave-induced plasma and excited to higher energy levels. When the electrons return to their stable state, they emit light, which passes into a spectrophotometer. The light is separated by a diffraction grating into wavelengths characteristic of the element selected for analysis (in this case, chlorine, but the instrument can also analyze for hydrogen, carbon, nitrogen, sulfur, oxygen, and several metals and other halogens) and transmit to a photodiode array detector, which can be tuned to monitor a specific range of wavelengths, depending on the element(s) of interest.

To quantitate chlorine, the photodiode array is tuned to monitor the 479-nanometer wavelength, which is characteristic of the energy emission from chlorine atoms. When energy of this wavelength is detected, it is converted into an electrical signal, the intensity of which is proportional to a specific quantity of chlorine atoms. The electrical signal intensity of each detected chlorine-containing compound is directly related to the amount of chlorine contained in the total amount of the compound present. For this reason, GC/AED (by itself) is useful in providing accurate total "gas chromatographable" chloride concentration values, but may or may not provide accurate concentration values for chloride-containing compounds, depending on how many chloride atoms a compound has. For example, if only GC/AED data are used, a compound with two chloride atoms will appear twice as concentrated as an equal amount of a compound with one chloride atom. Quantitating the concentrations of individual chloride-containing species can be done using GC/AED analysis in conjunction with GC/mass spectrometry (GC/MS) analysis to determine a species' degree of chloride substitution. This does not mean the organic chloride level will be inaccurate using GC/AED alone, but rather that a compound with one chlorine will appear less concentrated than a compound with two or more chlorine atoms. Therefore GC/AED alone cannot be used to quantify the chlorinated compound, but can be used to quantify organically associated chlorine of the liquid, overall. In this 
work, in which GC/AED alone was used to quantitate total organic chloride, 1-chloronaphthalene was used to calibrate the detector's chloride response.

Because GC/AED is a chromatographic technique, its use in determining organic chloride concentrations is valid for samples that contain no significant quantities of nonchromatographable organic species. Use of the technique in this work is probably worthwhile, since the plastics decomposition liquids analyzed appear to be composed primarily of volatile species.

Chlorine distributions for runs that contained measurable organic chloride are shown in Figures B.1 through B.5.

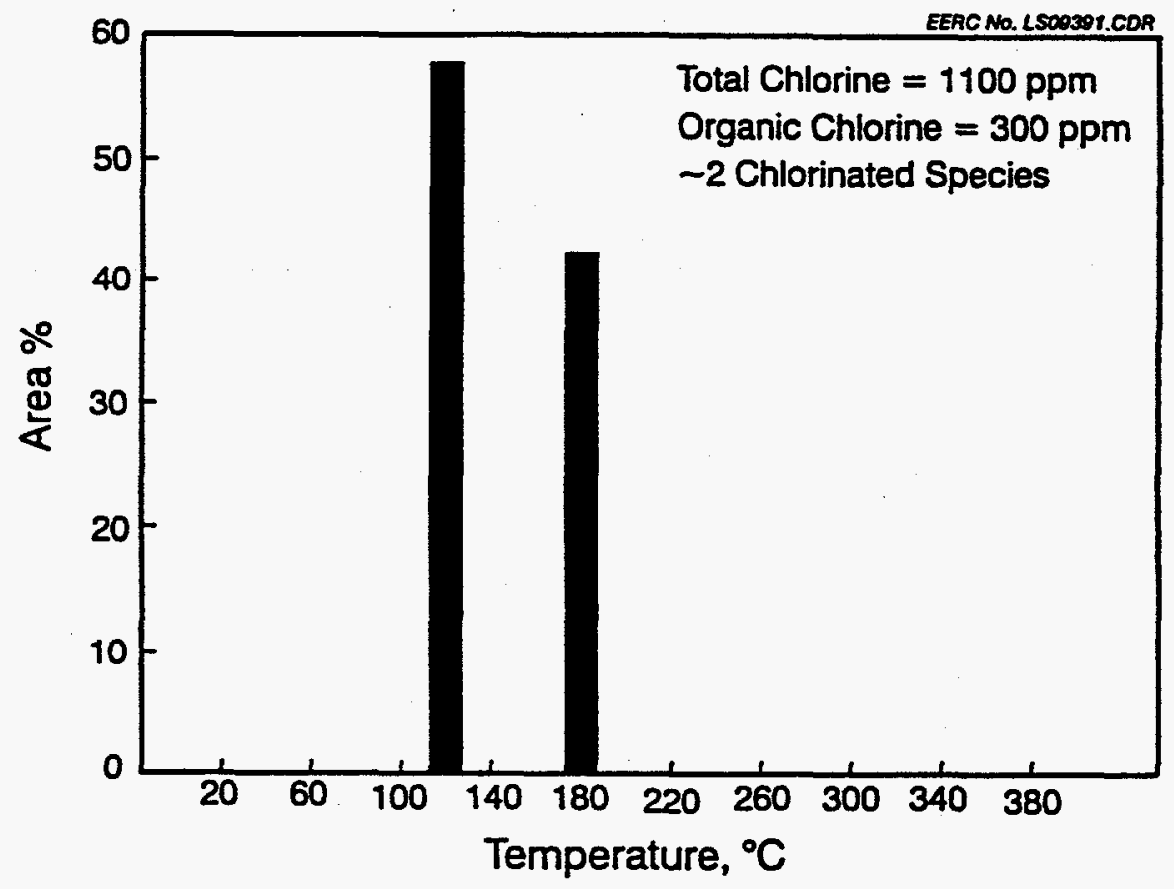

Figure B.1. Organic chlorine distribution for liquids produced at a depolymerization temperature of $440^{\circ} \mathrm{C}$ (M359). 


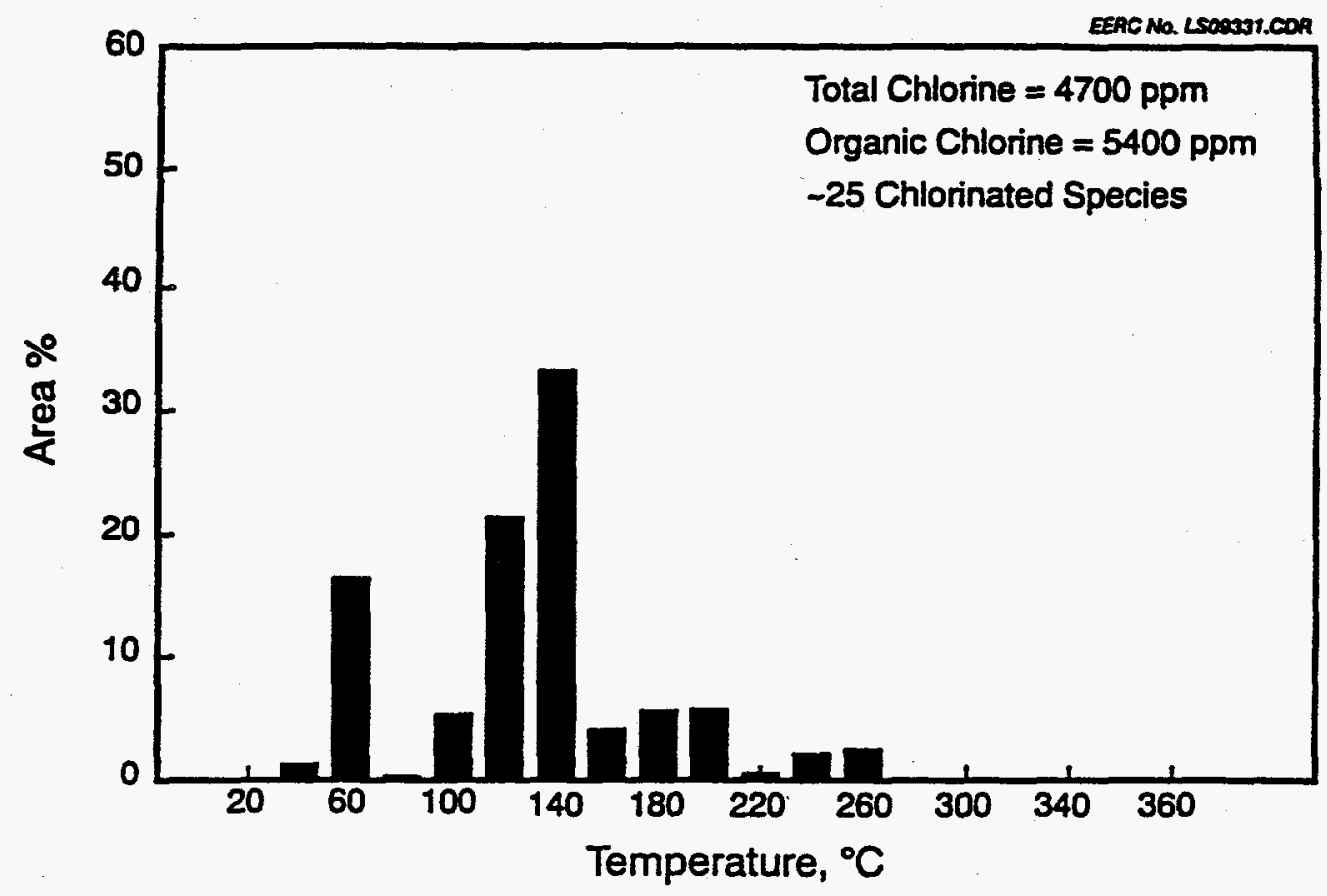

Figure B-2. Organic chlorine distribution for liquids produced at a depolymerization temperature of $540^{\circ} \mathrm{C}$ (M357).

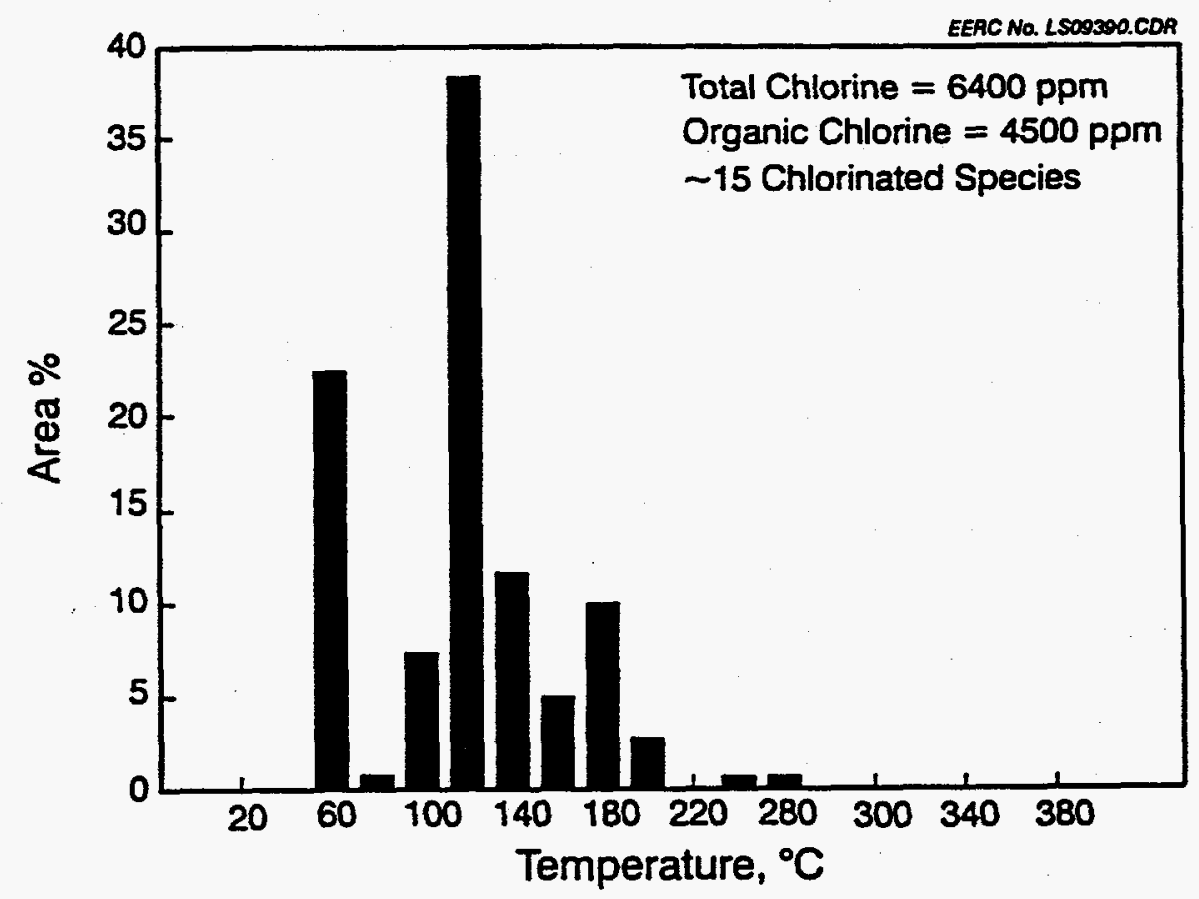

Figure B-3. Organic chlorine distribution for liquids produced at a depolymerization temperature of $540^{\circ} \mathrm{C}$ (M364). 


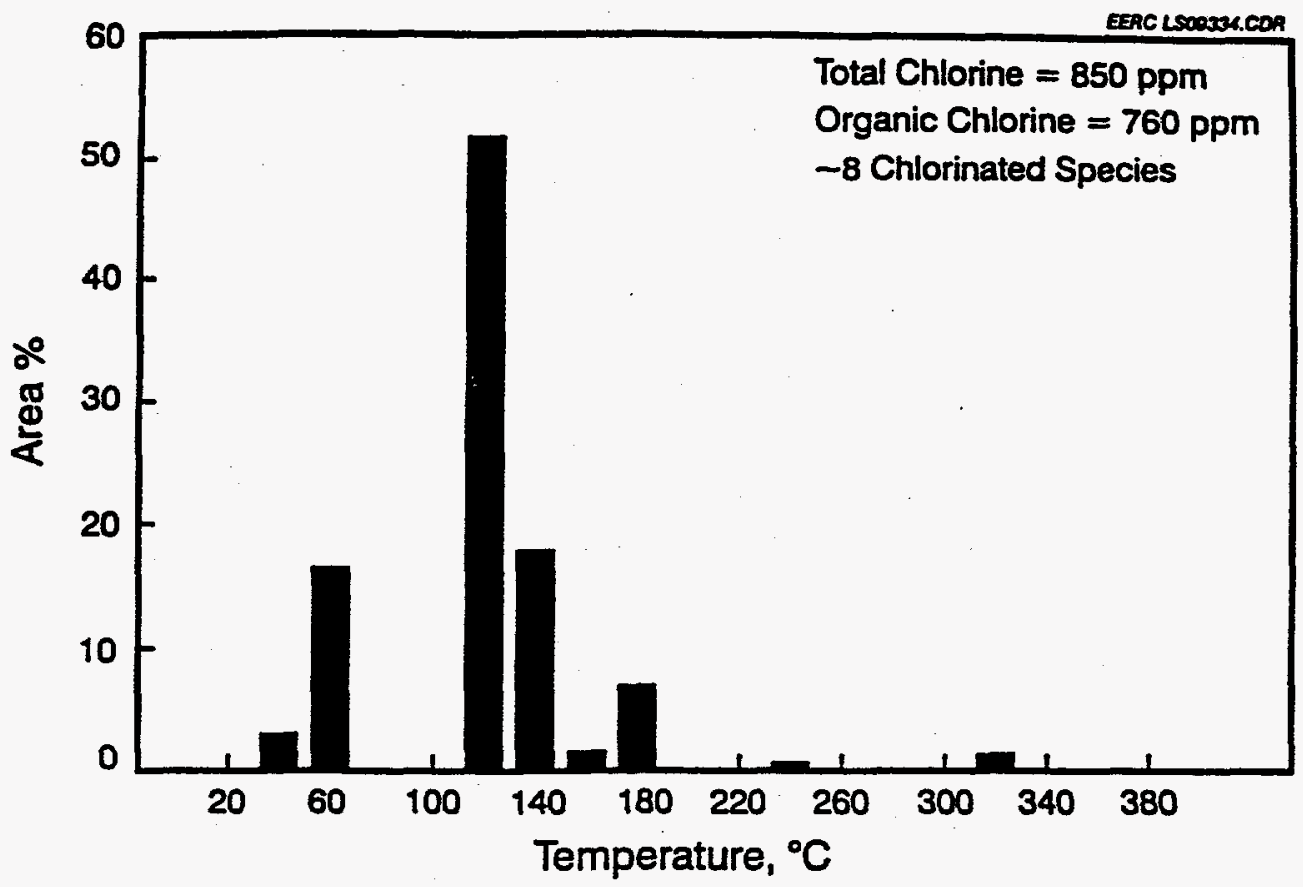

Figure B-4. Organic chlorine distribution for liquids produced at a depolymerization temperature of $440^{\circ} \mathrm{C}$ and a filter temperature of $340^{\circ} \mathrm{C}$ (M360).

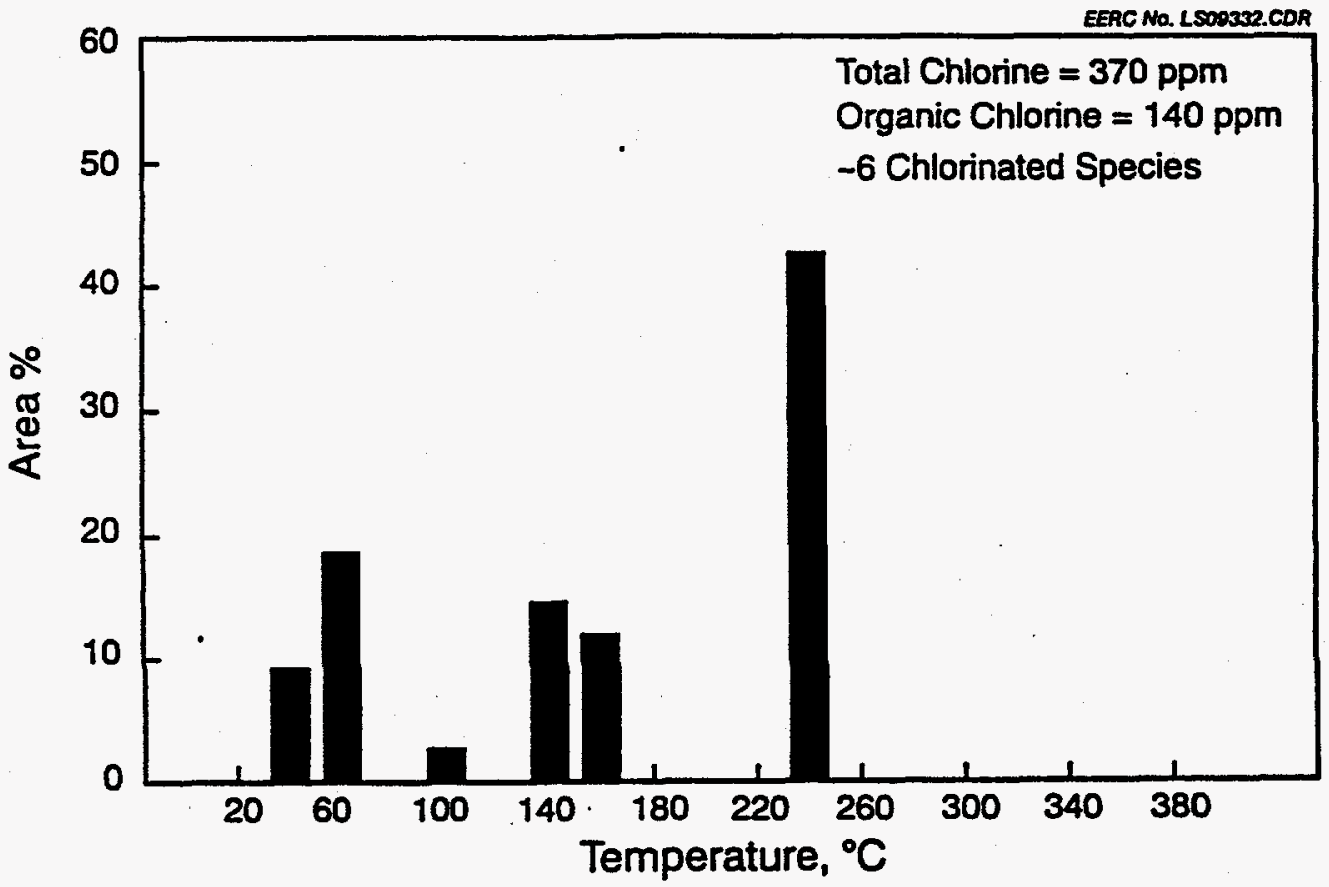

Figure B-5. Organic chlorine distribution for liquids produced at a depolymerization temperature of $540^{\circ} \mathrm{C}$ and a filter temperature of $340^{\circ} \mathrm{C}$ (M357). 


\section{GC/AED ORGANIC CHLORINE ANALYSIS OF PLASTICS DECOMPOSITION LIQUIDS DETECTION LIMIT/QUALITY CONTROL STUDY}

A study was conducted at the Energy \& Environmental Research Center (EERC) in Grand Forks, North Dakota, to determine the detection limit lowest detectable concentration) of organic chlorine in plastics decomposition liquids using gas chromatography coupled with atomic emission detection (GC/AED). The study consisted of analyzing a base material and three successively less concentrated dilutions of the base material. The results of this limited study indicate a per-compound detection limit of about 4 parts per million (ppm) organic chlorine. It must be stressed that the 4-ppm value is an indication of a detection limit and that a more comprehensive study would be required to establish a statistically valid detection limit.

Several decomposition products from both the EERC and the Energy \& Environmental Research (EER) Corporation in Irvine, California, were considered as a base material for the study. APC-106 from EER was chosen for the following reasons:

- While many decomposition products are waxy, sludgy materials at room temperature, APC-106 is a liquid with the approximate viscosity of a heavy fuel oil. Liquids can be accurately sampled, mixed, and solubilized without heat, which eliminates the possibility of boiling away volatile chlorine species.

- APC-106 has been analyzed for organic chlorine twice at the EERC and at least once at Core Laboratories in California; all three analyses provided similar results:
EERC $111,300 \mathrm{ppm}$
EERC $210,300 \mathrm{ppm}$
Core $1 \quad 11,000 \mathrm{ppm}$

- APC-106 has a wide concentration range of chlorine-containing species. In the two EERC analyses, APC-106 was found to be composed of about 30 organic chlorinecontaining species, ranging in concentration from less than $1.0 \%$ to about $24 \%$ of the total organic chlorine content.

Table C-1 provides results of the two EERC analyses of APC-106, and the following table provides results of triplicate analyses of the three APC-106 dilutions. The following definitions apply to both tables:

IS1/nS2 Area counts of Internal Standard 1 (2-chloronaphthalene) divided by area counts of Internal Standard 2 (1-chloronaphthalene)

IS1+IS2 Area counts of Internal Standard 1 plus area counts of Internal Standard 2

Total-IS Total area counts minus IS1+IS2

ISTD, $\mathbf{g}$ Weight of Internal Standard in grams

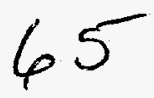




$$
\begin{array}{ll}
\mathrm{Sx}, \mathrm{g} & \text { Weight of sample in grams } \\
\mathrm{Cl}, \mathrm{ppm} & \text { Organic chlorine content in parts per million } \\
\mathrm{BPI},{ }^{\circ} \mathrm{C} & \begin{array}{l}
\text { Boiling point index (calculated boiling point based on relationship of } \mathrm{GC} \\
\text { retention time to boiling point for the series of normal alkanes from } \mathrm{C}_{5} \\
\text { to } \mathrm{C}_{15} \text { ) }
\end{array}
\end{array}
$$

RT GC retention time

AC $\quad$ GC area counts

Table C-1 indicates the reproducibility of the analysis technique. In both analyses, the same five compounds (with boiling point indices of $47^{\circ}, 86^{\circ}, 113^{\circ}, 126^{\circ}$, and $153^{\circ} \mathrm{C}$ ) accounted for about $70 \%$ of the total organic chlorine. Regarding the internal standard (ISTD), the original intent was to use 1-chloronaphthalene, but analysis revealed that 2-chloronaphthalene was present as an impurity in the 1-chloronaphthalene. This turned out to be advantageous, because it enabled calculation of an area count ratio (IS1/NS2) for the two compounds. If this ratio is consistent over the course of a series of analyses, it indicates that 1) neither species is present in the samples (this is required for overall quantitative accuracy-if chloronaphthalene is found in a sample, a different ISTD must be used in the analysis of that sample) and 2) the instrument is providing accurate and reproducible area count data.

In Table C-1, the two analyses are merged to allow easy comparison of area count data. Gaps in the columns indicate that the instrument detected a compound in one analysis but did not find the same compound in the other analysis. These errors are because of judgement differences in establishing a baseline from which to integrate the AED response for chlorine-containing compounds. As shown in the table, none of these inconsistently present compounds accounts for more than $2 \%$ of the total organic chlorine content, and the cumulative effect of all of them is 3.1\% for APC-106a and 4.8\% for APC. $106 \mathrm{~b}$. Also of significance in the analysis of the base material are the ISTD area count values of 399 and 297 for APC-106a and APC-106b, respectively, and the weight ratio of ISTD to sample $(0.011 / 1.010=0.011)$. These numbers will be compared to their counterparts in the analysis of the base material dilutions.

In order to prepare dilutions of the base material, a liquid was needed in which the base material was soluble at room temperature. Because the base material was produced from a feedstock containing 10\% PVC in a mixture of polyethylene (PE), polypropylene (PP), and polystyrene (PS), it was determined that a dilution liquid made from a similar feedstock would have the best solubilization capability. The dilution liquid (DL) was prepared by mixing $6 \mathrm{~mL}$ of a PP decomposition product (EERC-M269) with $14 \mathrm{~mL}$ of a $50 \% \mathrm{PE} / 50 \%$ PS decomposition product (EERC-M291). The three base material dilutions were prepared as follows:

$$
\begin{aligned}
& \text { No. } 1 \quad 0.5 \mathrm{~mL}(0.418 \mathrm{~g}) \mathrm{APC} \cdot 106 \text { was added to } 4.5 \mathrm{~mL}(3.743 \mathrm{~g}) \mathrm{DL} . \\
& \text { No. } 2 \text { About } 0.05 \mathrm{~mL}(0.056 \mathrm{~g}) \mathrm{APC}-106 \text { was added to } 5.0 \mathrm{~mL}(4.121 \mathrm{~g}) \mathrm{DL} . \\
& \text { No. } 3 \quad 0.010 \mathrm{~g} \mathrm{APC}-106 \text { was added to about } 8 \mathrm{~mL}(6.890 \mathrm{~g}) \mathrm{DL} .
\end{aligned}
$$

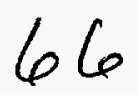


Based on the average of the three base material analyses, the chlorine content of the base material is about $10,900 \mathrm{ppm}$. Therefore, assuming good mixing and solubilization of the base material in the DL (which seems reasonable because of lack of visual evidence of precipitation or cloudiness), the chlorine content of the three dilutions should be about $1100 \mathrm{ppm}, 150 \mathrm{ppm}$, and $16 \mathrm{ppm}$, respectively, for No. 1, No. 2, and No. $3(\mu \mathrm{g} / \mathrm{g}$ and ppm are equivalent-see Table C-2). Table C-2 shows the merged results of the triplicate analyses of the three dilutions. To avoid any effects of analysis repetition, the dilutions were analyzed in the order shown in the table (APC-1 through APC-9).

The table shows that in all three analyses of No. 1 and No. 2, the analyzed chlorine content was higher than the calculated value. The reason for this is unknown and would require more testing to determine, but comparison of the three analyses of No. 1 and the three analyses of No. 2 shows that in both cases the greatest chlorine content error is associated with the smallest ISTD area count value. This indicates valid relationship between the accuracy of analyzed chlorine content and the magnitude of the ISTD area count value and the establishment of a minimum ISTD area count value. Based on the available data, it appears that reasonable accuracy should be possible, provided the ISTD area count value for an analysis exceeds 1800 . This does not mean that if the ISTD area count is below 1800 the analysis will not be accurate; it means that the chance for inaccuracy is greater. In the case of the base material analyses, it must be remembered that the ISTD-to-sample ratio was about 0.011 , whereas with the dilution analyses, the ISTD-to-sample ratios were about $0.013(0.011 / 0.824)$, a difference of about $22 \%$. Also, three separate analyses of the base material, using two different samples, yielded three similar chlorine content values.

Of the three analyses of Dilution No. 3 (the least concentrated), only APC-4 detected a response for a compound other than the two ISTDs. The ISTD area count for APC-4 was 1868, while the other two area count values were less than 500. A small ISTD area count is indicative of a small GC injection volume, the reason for which may involve sample viscosity and the small inside diameter of the injection needle. However, this should not be a problem-if an injection size is small, the analysis can be repeated until a representative sample (as defined by an ISTD area count of over 1800) is injected.

The following rationale was used to yield an indication of the detection limit of the GC/AED method for organic chlorine analysis:

Based on the average base material total organic chlorine content of 10,900 , the concentration of the most concentrated component (BPI of $47^{\circ} \mathrm{C}$ ) of the base material was calculated to be $2600 \mathrm{ppm}$. The concentration of this component in Dilution No. 3 (assuming proper mixing and solubilization) was calculated to be about $4 \mathrm{ppm}$. Because this 4-ppm component was detected in a representative sample injection, it seems reasonable to assume that the detection limit is at least $4 \mathrm{ppm}$ (per component), provided an adequate sample volume is injected (as defined by an ISTD area count value of at least 1800).

Concerning the use of GC/AED to quantitate organic chlorine in APC plastics decomposition liquids, the primary implication of this limited study is that the technique will detect chlorine-containing species present at concentrations of $4 \mathrm{ppm}$ or higher. Hence, the possibility exists that if a product contains 100 -ppm organic chlorine distributed among 40 compounds, none of which individually comprise more than $3 \mathrm{ppm}$

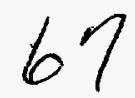


of the total organic chlorine content, the technique may yield an organic chlorine content of zero for this product. However, this is unlikely, because in analyses of products from both the EERC and EER Corporation, the same five components normally account for about $50 \%$ to $70 \%$ of the organic chlorine content. In products with lower chlorine contents (from 200 to $1000 \mathrm{ppm}$ ), these same five components appear to account for about $70 \%$ to $90 \%$. While it is possible that product liquids with lower organic chlorine contents have lower degrees of chlorine compound speciation, it is more likely that at lower organic chlorine levels, fewer species are present in above-detection-limit concentrations. In a hypothetical analysis, if only the above-mentioned five compounds were detected, all at concentrations of $4 \mathrm{ppm}$, the analyzed organic chlorine content of $20 \mathrm{ppm}$ would probably account for less than the actual content, which would probably range from about 25 to 50 ppm.

In addition to enabling quantitation of total organic chlorine, GC/AED data provides useful information regarding product volatility. In comparing samples analyzed at different times, it is important to remember that GC boiling point indices can vary by about $3^{\circ} \mathrm{C}$, because of differences in chromatographic conditions and the use of different alkane mixtures for boiling point calibration. 
TABLE C-1

Analytical Reproducibility

\begin{tabular}{ccc}
\hline & Base Material & \\
\hline IS1/IS2 & APC-106a & APC-106b \\
IS1+IS2 & 0.140 & 0.142 \\
Total-IS & 399 & 297 \\
ISTD, g & 1833 & 1245 \\
Sx, g & 0.011 & 0.011 \\
Cl, ppm & 1.010 & 1.010 \\
& 11307 & 10318
\end{tabular}

\begin{tabular}{|c|c|c|c|c|c|c|}
\hline & & $\begin{array}{l}\text { Organ } \\
\text { APC-1 }\end{array}$ & rine & ributi & PC-10 & \\
\hline$\overline{B P I},{ }^{\circ} \mathrm{C}$ & RT & $\overline{\mathrm{AC}}$ & $\mathrm{A} \%$ & RT & $\mathrm{AC}$ & $\mathrm{A \%}$ \\
\hline 47 & 1.33 & 447 & 24.4 & 1.28 & 303 & 24.3 \\
\hline 53 & 1.47 & 6 & 0.3 & & & 0.0 \\
\hline 64 & & & 0.0 & 1.71 & 13 & 1.0 \\
\hline 68 & & & 0.0 & 1.82 & 22 & 1.8 \\
\hline 73 & & & 0.0 & 1.96 & 6 & 0.5 \\
\hline 81 & 2.65 & 14 & 0.8 & 2.55 & 15 & 1.2 \\
\hline 86 & 2.99 & 151 & 8.2 & 2.89 & 111 & 8.9 \\
\hline 91 & & & 0.0 & 3.20 & 6 & 0.5 \\
\hline 102 & & & 0.0 & 4.09 & 9 & 0.7 \\
\hline 104 & 4.35 & 67 & 3.7 & 4.24 & 55 & 4.4 \\
\hline 113 & 5.12 & 280 & 15.3 & 5.00 & 209 & 16.8 \\
\hline 118 & 5.59 & 84 & 4.6 & 5.48 & 59 & 4.7 \\
\hline 119 & 5.73 & 10 & 0.5 & & & 0.0 \\
\hline 126 & 6.37 & 288 & 15.7 & 6.25 & 151 & 12.1 \\
\hline 129 & 6.59 & 44 & 2.4 & 6.47 & 27 & 2.2 \\
\hline 133 & 6.97 & 16 & 0.9 & 6.87 & 11 & 0.9 \\
\hline 133 & 7.05 & 12 & 0.7 & 6.93 & 10 & 0.8 \\
\hline 136 & 7.27 & 23 & 1.3 & 7.15 & 13 & 1.0 \\
\hline 139 & 7.57 & 42 & 2.3 & 7.45 & 20 & 1.6 \\
\hline 139 & 7.64 & 6 & 0.3 & 7.51 & 4 & 0.3 \\
\hline 140 & 7.65 & 8 & 0.4 & & & 0.0 \\
\hline 146 & 8.25 & 22 & 1.2 & 8.13 & 10 & 0.8 \\
\hline 150 & 8.66 & 17 & 0.9 & 8.54 & 16 & 1.3 \\
\hline 153 & 8.92 & 126 & 6.9 & 8.79 & 93 & 7.5 \\
\hline 154 & 9.06 & 33 & 1.8 & 8.94 & 21 & 1.7 \\
\hline 164 & 10.01 & 13 & 0.7 & 9.88 & 6 & 0.5 \\
\hline
\end{tabular}

(continued...) 
TABLE C-1 (continued)

\begin{tabular}{ccclccc}
\hline \multicolumn{7}{c}{ Base Material } \\
\hline BPI, ${ }^{\circ} \mathrm{C}$ & RT & AC & A\% & RT & AC & A\% \\
\hline 165 & 10.10 & 8 & 0.4 & & & 0.0 \\
173 & 10.81 & 17 & 0.9 & 10.68 & 5 & 0.0 \\
173 & 10.83 & 14 & 0.8 & 10.86 & 8 & 0.4 \\
175 & 10.99 & 11 & 0.6 & & & 0.0 \\
180 & 11.54 & 8 & 0.4 & & & 0.0 \\
184 & 11.85 & 4 & 0.2 & 12.02 & 16 & 1.3 \\
187 & 12.15 & 15 & 0.8 & 12.68 & 4 & 0.3 \\
194 & & & 0.0 & 13.10 & 22 & 1.8 \\
199 & 13.23 & 47 & 2.6 & 17.65 & 37 & IS \\
247 & 17.80 & 49 & IS & 17.72 & 260 & IS \\
247 & 17.87 & 350 & IS & & & \\
\hline
\end{tabular}


TABLE C-2

Dilution Analyses

\begin{tabular}{|c|c|c|c|c|c|c|c|c|c|c|c|c|c|c|c|c|c|c|}
\hline \multirow{2}{*}{$\begin{array}{c}\text { Dilution: } \\
\text { Name: }\end{array}$} & \multicolumn{6}{|c|}{ No. $1,1100 \mathrm{Fg} / \mathrm{g}$} & \multicolumn{6}{|c|}{ No. $2,150 \mathrm{Fg} / \mathrm{g}$} & \multicolumn{6}{|c|}{ No. $3,16 \mathrm{Fg} / \mathrm{g}$} \\
\hline & \multicolumn{2}{|c|}{ APC3-3 } & \multicolumn{2}{|c|}{ APC3-6 } & \multicolumn{2}{|c|}{ APC3-9 } & \multicolumn{2}{|c|}{ APC3-2 } & \multicolumn{2}{|c|}{ APC3.5 } & \multicolumn{2}{|c|}{ APC3-8 } & \multicolumn{2}{|c|}{ APC3-1 } & \multicolumn{2}{|c|}{ APC3-4 } & \multicolumn{2}{|c|}{ APC3-7 } \\
\hline IS1/IS2 & \multicolumn{2}{|c|}{0.137} & \multicolumn{2}{|c|}{0.136} & \multicolumn{2}{|c|}{0.141} & \multicolumn{2}{|c|}{0.133} & \multicolumn{2}{|c|}{0.135} & \multicolumn{2}{|c|}{0.139} & \multicolumn{2}{|c|}{0.128} & \multicolumn{2}{|c|}{0.140} & \multicolumn{2}{|c|}{0.135} \\
\hline $\mathbf{I S 1}+\mathbf{I S 2}$ & \multicolumn{2}{|c|}{2485} & \multicolumn{2}{|c|}{301} & \multicolumn{2}{|c|}{2393} & \multicolumn{2}{|c|}{2076} & \multicolumn{2}{|c|}{4928} & \multicolumn{2}{|c|}{654} & \multicolumn{2}{|c|}{132} & \multicolumn{2}{|c|}{1868} & \multicolumn{2}{|c|}{487} \\
\hline TotalBIS & \multicolumn{2}{|c|}{1087} & & & & & & & & & & & & & & & & \\
\hline ISTD, 8 & & & & & & & & & & & & & & & & & & \\
\hline Sx, g & & & & & & & & & & & & & & & & & & \\
\hline $\mathrm{Cl}, \mathrm{ppm}$ & & & & & & & & & & & & & & & & & & \\
\hline BPI, EC & RT & $\mathrm{AC}$ & $\mathbf{R T}$ & $\mathrm{AC}$ & RT & $\mathbf{A C}$ & $\mathbf{R T}$ & $\mathrm{AC}$ & RT & $\mathrm{AC}$ & RT & $\mathrm{AC}$ & RT & $\mathbf{A C}$ & $\mathbf{R T}$ & $\mathrm{AC}$ & RT & AC \\
\hline 47 & 1.36 & 206 & 1.37 & 55 & 1.36 & 193 & 1.38 & 23 & 1.37 & 42 & 1.38 & 11 & & & 1.38 & 6 & & \\
\hline & & & & & 2.52 & 6 & & & . & & & & & & & & & \\
\hline & 2.62 & 8 & & & 2.61 & 8 & & & & & & & & & & & & \\
\hline & & & & & & & & & 2.83 & 5 & & & & & & & & \\
\hline 86 & 2.97 & 82 & 2.99 & 18 & 2.97 & 69 & 2.98 & 15 & 2.97 & 18 & & & & & & & & \\
\hline & 3.68 & 8 & & & & & & & & & & & & & & & & \\
\hline & 4.15 & 6 & & & 4.14 & 13 & & & & & & & & & & & & \\
\hline
\end{tabular}


TABLE C.2 (continued)

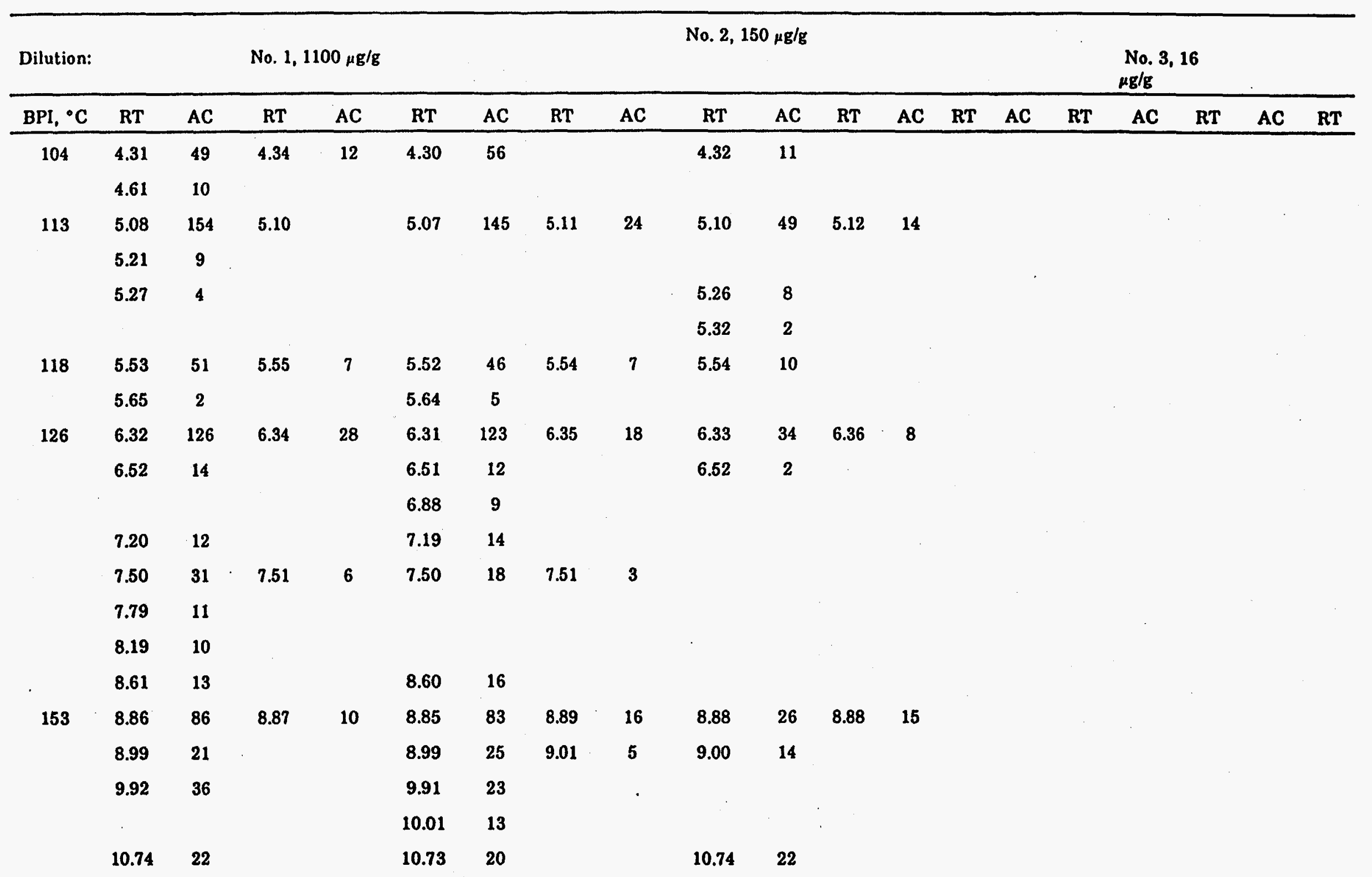

(continued...) 
TABLE C-2 (continued)

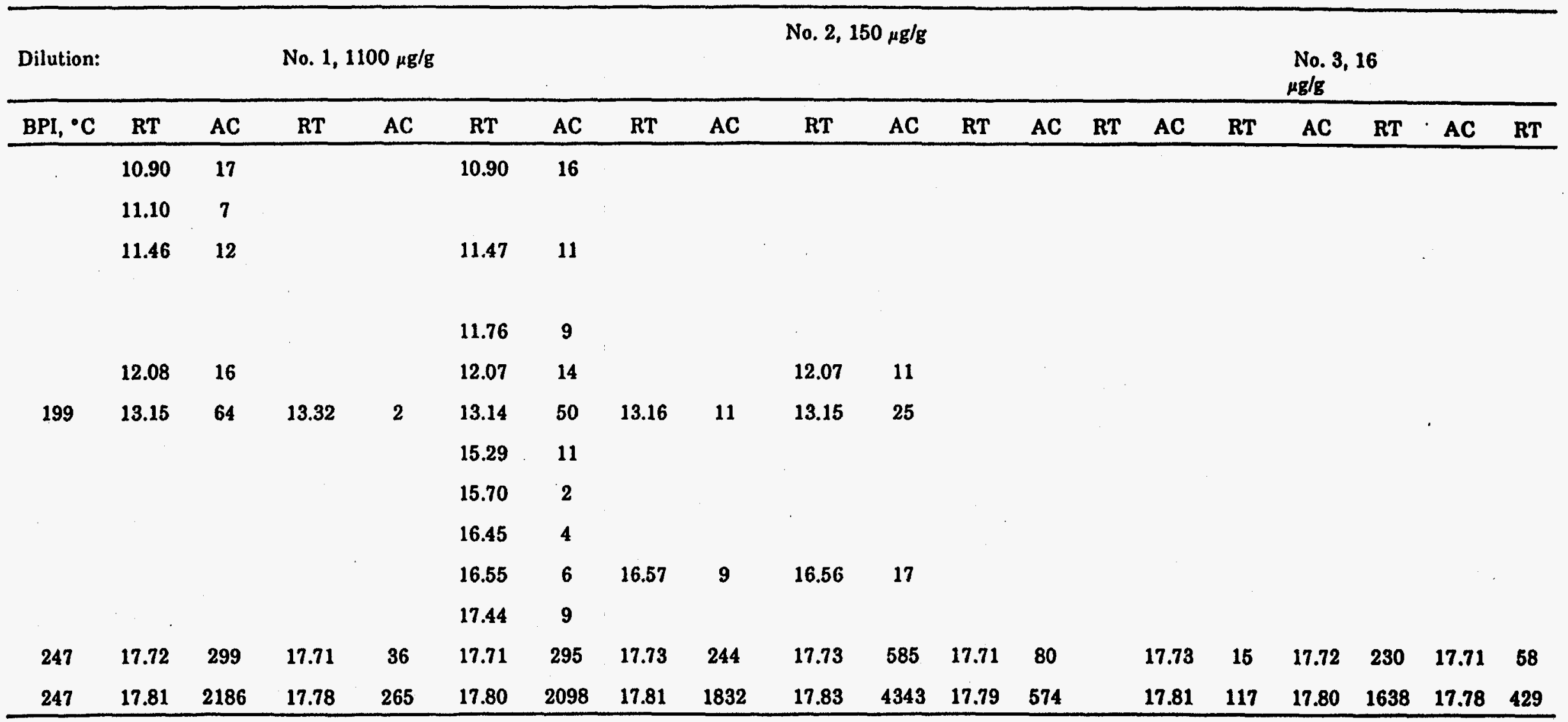

(continued...) 



\section{TEREPHTHALIC ACID QUANTIFICATON}

The terephthalic acid (TA) analysis method (West, J.C., Analytical Chemistry 1975, 47, 1708, and Knapp, D.R., Handbook of Analytical Derivatization Reactions, John Wiley \& Sons, 1979 ; p. 221) used in this project is a two-step process consisting of 1) esterification of TA to its methyl ester, dimethyl terephthalate (DMT) and 2) quantitation of DMT using GC-FID. Accurate quantitation requires construction of a calibration curve based on gas chromatography-flame ionization detection (GC-FID) analysis of a series of analytical standards representative of a DMT concentration range that "brackets" the DMT concentration value yielded by the analytical sample. Because the molar ratio of DMT to TA is 1:1, wt\% TA in a sample can be calculated based on the weight ratio of DT to TA (194:166). In addition to TA, the method will convert other carboxylic acids present in a sample to their respective methyl esters, which can then also be quantitated in the same manner. Work to date has indicated that benzoic acid is the only other carboxylic acid present in greater than trace amounts in any of the samples tested. In order to ensure sample homogeneity (and representative results), all derivatizations should be performed using material obtained from a sample that has been thoroughly mixed with an electric blender. The standard operating procedure (SOP) used for TA derivatization is as follows:

\section{Standard Operating Procedure for Ta Derivatization}

1. The condensate sample is blended (to ensure homogeneity) for at least 2 minutes using a laboratory blender.

2. An approximate 75 - to 100 -milligram (mg) aliquot of the blended sample is weighed into a 50 -milliliter $(\mathrm{mL})$ flask, $1.0 \mathrm{~mL}$ of methanol and $1.0 \mathrm{~mL}$ of tetramethylammonium hydroxide (TMAH) are added, and the mixture is refluxed for 10-15 minutes (min) or until all solids are dissolved.

3. Ten $\mathrm{mL}$ of dimethyl formamide (DMF) and $1 \mathrm{~mL}$ of internal standard ( $n$-octadecane in dichloromethane) are added, and the solution is mixed.

Warning: Extreme Caution Should Be Employed in the Use of Methyl Iodide, as it Has the Potential of Producing Severe Narcosis.

4. One $\mathrm{mL}$ of methyl iodide $\left(\mathrm{CH}_{3} \mathrm{I}\right)$ is added, the solution is mixed, and tetramethylammonium iodide precipitate (formed in the reaction of TMAH with any carboxylic acid [s] present) is separated by centrifugation.

5. An aliquot of the supernatant is analyzed for TA quantitation using GC-FID.

The SOP for DMT quantitation, which is performed using an HP 5890A gas chromatograph equipped with a Petrocol capillary column, is as follows: 


\section{Standard Operating Procedure for Dmt Quantitation}

1. An internal standard (ISTD) solution is prepared by dissolving a known weight of $n$-octadecane into a known volume of dichloromethane to produce a $100-\mu \mathrm{g} / \mathrm{mL}$ solution of $n$-octadecane.

2. Stock solutions containing $1200,600,250,100,50$, and $25 \mu \mathrm{g} / \mathrm{mL}$ of DMT, each also containing $100 \mu \mathrm{g} / \mathrm{mL}$ of $n$-octadecane ISTD, are prepared.

3. One $\mu \mathrm{L}$ of each solution is injected into the $\mathrm{GC}$ and analyzed, using the following temperature program and GC conditions:

Initial temperature: $30^{\circ} \mathrm{C}$

$30^{\circ}$ to $40^{\circ} \mathrm{C} @ 0.5^{\circ} \mathrm{C} / \mathrm{min}$

$40^{\circ}$ to $300^{\circ} \mathrm{C} @ 2^{\circ} \mathrm{C} / \mathrm{min}$

Carrier gas: $\mathrm{H}_{2} @ 3 \mathrm{~mL} / \mathrm{min}$ at $25^{\circ} \mathrm{C}$

Makeup gas: $\mathrm{N}_{2}$

Split ratio: $40: 1$

4. Data gathered from these analyses will be used to generate a calibration table (from which a DMT response factor is calculated-see Step 6) that is stored on the hard drive of the GC computer. A calculation program can then be used to compute DMT amount (in grams) in a sample using the calibration table, the ISTD amount, and DMT and ISTD area count data for the sample.

5. To check the accuracy of the calibration table, two DMT solutions of known concentration will be prepared and analyzed.

6. Calculation of DMT amount in a sample is performed as follows:

$$
\begin{aligned}
a_{\mathrm{DT}}= & \left(\left[\left(\mathrm{ac}_{\mathrm{DMT}}\right)\left(\mathrm{rsp}_{\mathrm{DMT}}\right)\right] /\left[\left(\mathrm{ac}_{\mathrm{ISTD}}\right)\left(\mathrm{rsp}_{\mathrm{ISTD}}\right)\right]\right)\left(\mathrm{amt} \mathrm{ISTD}_{\mathrm{IST}}\right) \\
\text { where: } & \mathrm{ac}=\text { area counts } \\
& \mathrm{amt}=\text { amount, in grams } \\
& \mathrm{rsp}=\text { response factor (calibration amt/calibration ac) }
\end{aligned}
$$

7. Calculation of TA amount is then performed as follows:

$$
\mathrm{amt}_{\mathrm{TA}}=\left(a m t_{\mathrm{DMT}}\right)(166: 194)
$$

where: $166: 194=$ TA:DMT molar weight ratio in grams $/$ mole 
8. Calculation of TA concentration is then performed as follows:

$$
\operatorname{conc}_{\mathrm{TA}}=\left[\left(\mathrm{amt}_{\mathrm{TA}}\right) /\left(\mathrm{amt}_{\text {sample }}\right)\right](100 \%)
$$

To investigate the accuracy of the method, $0.0172 \mathrm{~g}$ of TA (Aldrich Chemicals, 18,536-1, $98 \%$ purity) was derivatized and analyzed. The calculated yield of TA was $0.0159 \mathrm{~g}$, which indicates (assuming an initial TA weight of $0.0169 \mathrm{~g}$, owing to $98 \%$ purity) a recovery of about $94 \%$. 


\section{GAS ANALYSIS}

Light olefins quantitation in balance-period gas samples is performed using a gas chromatography (GC) analysis method developed and published by Hewlett-Packard Company to provide "rapid determinations of fixed gases and light hydrocarbons in various refinery type gas mixtures, including minor concentrations of $\mathrm{C}_{6}+$ hydrocarbons." A complete description of the method is provided in "Refinery Gas Analyzer 18900C Option 816, Gas Chromatograph 5880A, "Hewlett-Packard Company, 1983. Samples can be injected into the GC from either a pressurized sample cylinder or gas bag. Samples for this project were injected into the GC from gas bags according to the following standard operating procedure (SOP).

\section{Standard Operating Procedure for Injection of Gas Bag Samples}

1. Attach gas bag to stainless steel sample inlet line with short piece of "Tygon" tubing.

2. Open gas bag valve.

3. Apply gentle pressure on gas bag for 2 minutes (this action will result in purging about 200 cubic centimeters of gas through the GC sample loops).

4. Close gas bag valve and press GC sample injection button to activate sample loop valves and initiate analysis.

The gas analysis provides mole percent (mol\%) concentration values for a specific set of gas compounds, including each of the light olefins of interest in this project, hydrogen, nitrogen, oxygen, carbon dioxide, carbon monoxide, and other hydrocarbons. Other outputs from the analysis include calculated heating value, calculated average molecular weight, and calculated "airbasis" specific gravity (defined as the ratio of the density of a particular gas to the density of air at standard temperature and pressure), obtained using the gas compound concentration data and published air-basis specific gravity values. In addition to the steps described in the above SOP for gas sample injection, each gas bag is tested for leaks during a "nitrogen rinse" as described in the following SOP for gas sample collection.

\section{Standard Operating Procedure for Gas Sample Collection}

1. Attach a gas bag to the house nitrogen line with Tygon tubing, open gas bag valve, fill gas bag to slightly under capacity with nitrogen, and close gas bag valve.

2. Attach full gas bag to house vacuum line with Tygon tubing, open bag valve, evacuate bag completely, and close bag valve.

3. Repeat Steps 1 and 2.

4. Fill bag with nitrogen a third time according to Step 1 and check bag (including valve) thoroughly for leaks. If a leak is detected, dispose of bag, obtain a new bag, and begin SOP again, starting with Step 1. 
5. If no leaks are detected, evacuate bag according to Step 2.

6. Attach nitrogen-rinsed bag to reactor system gas-sampling line with Tygon tubing.

7. Open gas bag valve, open reactor system vacuum valve, and evacuate sampling line and gas bag as a unit.

8. Close vacuum valve, open reactor system sampling valve, and fill gas bag with product gas.

9. Close reactor system sampling valve, close gas bag valve, remove gas bag from reactor system gas-sampling line, and deliver sample to gas analysis lab.

A single-point calibration of the $\mathrm{GC}$ for the light olefins analysis is performed using the three calibration gas mixtures (Cal-1, Cal-2, and Cal-4) listed in the accompanying "Calibration Gas Concentrations" table. Calibration is performed for each of the 21 components (analytes) listed in the table. The calibration procedure is described in "5880A Gas Chromatograph, Volume 5: Integration and Methods," Hewlett-Packard Company, 1979. All calibrations are performed using certified standard-grade calibration gas (cal gas) mixtures from Matheson Company, Houston, Texas. As shown in the cal gas listings, the calibration concentrations of the $C_{2}, C_{3}$, and $C_{4}$ olefins to be quantitated range from $0.731 \mathrm{~mol} \%$ for acetylene to $1.08 \mathrm{~mol} \%$ for 1,3-butadiene. Based on analyses performed in past EERC work, concentration ranges for these light olefins in depolymerization product gases normally range from about 0.5 to $1.5 \mathrm{~mol} \%$ for the $\mathrm{C}_{4}$ olefins and from about 1 to $5 \mathrm{~mol} \%$ for the $\mathrm{C}_{2}$ and $\mathrm{C}_{3}$ olefins. 
Calibration Gas Concentrations

$\underline{\mathrm{Cal}-1} \quad \underline{\mathrm{Cal}-2} \quad \underline{\mathrm{Cal}-3} \quad \underline{\mathrm{Cal}-4}$

\begin{tabular}{|c|c|c|c|c|c|}
\hline & Helium $(\mathrm{He})$ & 0.956 & & & \\
\hline 2 & Hydrogen (H2) & 29.47 & & & \\
\hline 3 & Carbon Dioxide (CO2) & 10.10 & 2.99 & & \\
\hline 4 & Propane (C3H8) & 0.981 & & & \\
\hline 5 & Propylene (C3H6) & & 0.986 & & \\
\hline 6 & Acetylene (C2H2) & & & & 0.731 \\
\hline 7 & iso-Butane $\left(i-C_{4}\right)$ & 0.483 & & & \\
\hline 8 & Carbonyl Sulfide (COS) & & & 0.205 & \\
\hline 9 & $n-B u \tan e(n-C 4)$ & 0.496 & & & \\
\hline 10 & Hydrogen Sulfide (H2S) & & & 0.972 & \\
\hline 11 & 1-Butene (1-Bu) & & 0.963 & & \\
\hline 12 & iso-Butylene $(i=\mathrm{Bu})$ & & & & 1.02 \\
\hline 13 & $\operatorname{tans}-2-$ Butene $(t-2-B u)$ & & 0.949 & & \\
\hline 14 & iso-Pentane (i-C5) & 0.495 & 0.993 & & \\
\hline 15 & cis-2-Butene $(c-2-B u)$ & & 0.958 & & \\
\hline 16 & $n$-Pentane $(n-C 5)$ & 0.492 & & & \\
\hline 17 & 1,3-Butadiene $(1,3-\mathrm{BDN})$ & & & & 1.08 \\
\hline 18 & Ethylene (C2H4) & & 1.04 & & \\
\hline 19 & Ethane (C2H6) & 0.975 & & & \\
\hline 20 & Oxygen (02) & 0.984 & & & 5.06 \\
\hline 21 & Nitrogen (N2) & 7.03 & 70.791 & 98.823 & 92.109 \\
\hline 22 & Methane (CH4) & 7.49 & 20.33 & & \\
\hline 23 & Carbon Monoxide (CO) & 40.048 & & & \\
\hline
\end{tabular}


APPENDIX C

MATERIAL BALANCE PROCEDURES SUMMARIES AND METHODS DESCRIPTION MATERIAL BALANCE CALCULATION METHODS 


\section{MATERIAL BALANCE SUMMARIES AND METHODS DESCRIPTION MATERIAL BALANCE CALCULATION METHODS}

Figure G1 is a material balance sheet for M268. This sheet will be used to help to explain how yields were calculated.

Components listed are polymer/solids (a generic reference to the component fed), water, condensables (organic liquids), and gas. The organic liquid section is broken down further as boiling point cuts. The gas section is also broken down further, by components. The first column, marked "Grams In," contains the grams of material fed to the process, broken down by component. For example, 3628 grams of PP and 2537 grams of nitrogen were fed over the material balance period for M268. The next column is "Grams Out," again broken down by component. The third column is "Yields." Yields for each component are calculated by dividing grams out of a component minus grams in by the grams of polymer fed. For example, the calculation of total liquid (cond.) yield for this run would be as follows:

$$
\frac{\text { Liquid grams out - liquid grams in }}{\text { Polymer fed }}=\frac{(3052.9-0)}{3628.0}=84.1 \%
$$

All columns are totalled at the bottom of the sheet. In this case, $6165.0 \mathrm{~g}$ of total material were fed to the process, and $5806.8 \mathrm{~g}$ of total material were collected. This corresponds to a $94.2 \%$ material closure, shown below the grams-out total. The yields do not add up to $100 \%$ because the material balance is not $100 \%$. These two numbers are not the same (94.2 and 90.1) because the yield calculation is based on polymer fed and the material balance number is based on total material fed and collected. The last column is labeled "N Yields." This column takes the difference between the material fed and the material collected and distributes it to one or more of the three product streams, based on tie elements. A tie element is a portion of a stream that does not take part in a reaction or is "inert." The only tie elements in these balances is nitrogen. Nitrogen into the system must equal nitrogen out of the system. No significant solid material or unreacted polymer was collected, so it was not available for use as a tie. In the case of M268, the difference between total material fed and total product collected is 358.2 grams. Five \% of this "missing" mass is assigned to the gas stream and 95\% to the liquid stream. This 5\% was based on the nitrogen balance in the gas stream, which allowed the nitrogen in to equal the nitrogen out. Five percent, or $17.9 \mathrm{~g}$, is distributed to the gas stream on a molar, or volume, basis. Since this is distributed on a molar basis, the mass assigned to the gas stream must be put on a molar basis by dividing by the average molecular weight of the gas, 28.79 .

$$
\frac{17.9}{28.79}=0.6217 \mathrm{~mol}
$$

Propylene is $2.3 \%$ of the product gas stream, so $2.3 \%$ of the 0.6217 moles is given to propylene.

$0.6217 \mathrm{~mol} \times 2.3 \%=0.0143 \mathrm{~mol}$ propylene

$0.0143 \mathrm{~mol} \times 42 \mathrm{~g} / \mathrm{g}-\mathrm{mol}=0.60 \mathrm{~g}$ propylene 
The normalized $(\mathrm{N})$ yield for propylene is as follows:

$\frac{\text { Gas grams out }- \text { gas grams in + normalization quantity }}{\text { Grams PP fed }}=\frac{(92.4-0)+(0.60)}{3628.0}=2.6 \%$

For the product liquids, there were 3052.9 grams collected. This equates to a yield of 84.1\%.

$$
\frac{3052.9}{3628.0} \times 100 \%=84.1 \%
$$

$95 \%$ of the mass loss $(0.95 \times 358.2=340.3)$ has been assigned to the liquid stream in this run. The normalized yield becomes:

$\frac{\text { Liquid grams out }- \text { liquid grams in + normalization quantity }}{\text { Grams PP fed }}=\frac{(3052.9-0+340.3)}{3628.0} \times 100 \%=93.5 \%$

The assignment of percentages to streams is shown in the lower left corner of the yields summary sheet. 


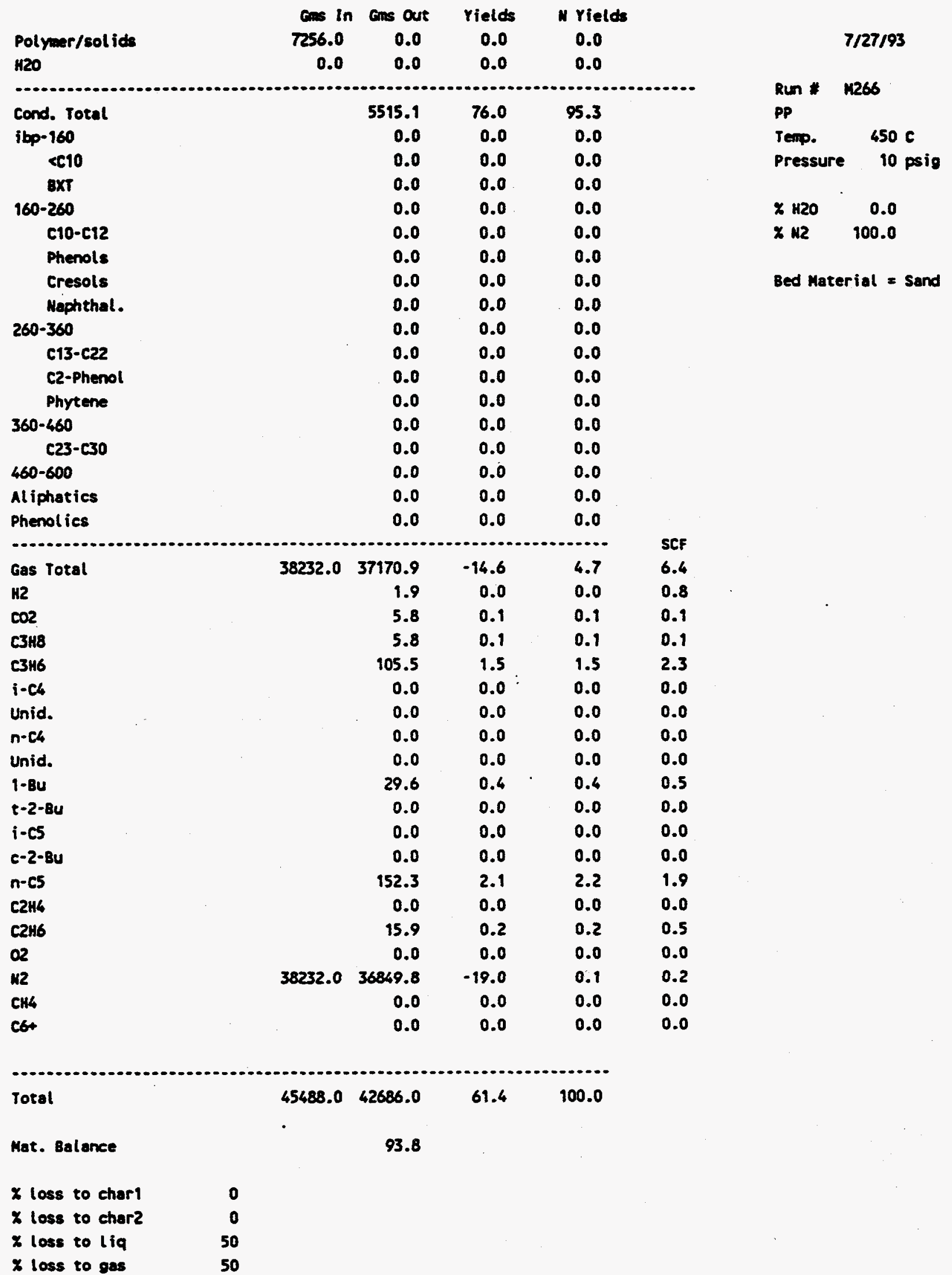

Figure G-1. Examples of material balance sheets. 
P036

Temp C

Press, psig

feedrate, Ib/hr

80

runtime, hrs

3

$\%$ Sand

5

plastics in, lbs

$\mathrm{CaO} / \mathrm{sand}$ in, lbs

water, Ibs

scrubbers

steam

Organic Liquids, Ibs

\section{Gas \\ $\mathrm{H} 2$ \\ $\mathrm{CO} 2$ \\ C3 \\ $\mathrm{C3}=$ \\ i-Bu \\ n-bu \\ unid \\ 1-but \\ $\mathrm{i}-\mathrm{C} 5$ \\ $n-C 5$ \\ $\mathrm{C} 2=$ \\ $\mathrm{C} 2$ \\ $\mathrm{O} 2$ \\ N2 \\ $\mathrm{CH} 4$ \\ CO}

i-butyl

t-2-but

c-2-but

avg mol wt

Total Gas + Water

Total mass

material balance
IN

228

12

53

120

14

OUT

0

19.9

YIELD

$0.0 \%$

$3.5 \%$

N YIELD

$0.0 \%$

$3.5 \%$

89

$32.9 \%$

$32.9 \%$

2.3

$1.0 \%$

$1.0 \%$

0

128.3

32.1

$56.3 \%$

$14.1 \%$

$55.5 \%$

0

0

0

39.1

$17.2 \%$

$13.9 \%$

0.0

$0.0 \%$

$16.9 \%$

0

0

9.1

$4.0 \%$

$0.0 \%$

0.0

$0.0 \%$

$3.9 \%$

6.8

$3.0 \%$

$0.0 \%$

0

0

0

6.8

$3.0 \%$

$2.9 \%$

2.3

$1.0 \%$

$2.9 \%$

0

0.0

$0.0 \%$

$1.0 \%$

0.0

$0.0 \%$

$0.0 \%$

0

0

0

0.0

$0.0 \%$

$0.0 \%$

31.8

$13.9 \%$

$0.0 \%$

0

199.5

887.7

7.3

$3.2 \%$

$13.7 \%$

0.0

$-87.5 \%$

$3.2 \%$

50.8

899.4

11.7

$5.2 \%$

$-87.5 \%$

0.0

25.0

$-17.1 \%$

$-0.0 \%$

$10.9 \%$

$-17.2 \%$

$10.8 \%$

29.7

1310.9

1471.9

$70.6 \%$

$63.6 \%$

1564.9

1580.8

$149.5 \%$

$100.0 \%$ $101.0 \%$

$\%$ to gas

$\%$ to liquids .

moles $\mathrm{O} 2 / \mathrm{CH} 4$ in $=$

2.0

$100.0 \%$

$0.0 \%$

$0.0 \%$ 
Temp C

P037

Press, psig

628

feedrate, lb/hr

runtime, hrs

100

\% CaOlsand

2.5

5

\section{plastics in, lbs}

$\mathrm{CaO} / \mathrm{sand}$ in, lbs

water, lbs

scrubbers

steam

Organic Liquids, Ibs
Gas

$\mathrm{H} 2$

$\mathrm{CO} 2$

C3

$\mathrm{C} 3=$

i-Bu

i-butyl

n-bu

unid

1-but

t-2-but

i-C5

c-2-but

$n-C 5$

$\mathrm{C2}=$

$\mathrm{C} 2$

$\mathrm{O} 2$

N2

$\mathrm{CH} 4$

$\mathrm{CO}$

avg mol wt

Total Gas + Water

Total mass

material balance
IN

237.5

12.5

320.0

19.3

52.0

0.0

0.0

0.0

0.0

0.0

0.0

0.0

0.0

0.0

0.0

0.0

0.0

0.0

0.0

0.0

170.9

744.1

39.7

0.0

1293.9
OUT

0

YIELD

$0.0 \%$

$-5.3 \%$

N YIELD

$0.0 \%$

$0.5 \%$

$\begin{array}{lll}0 & -5.3 \% & 0.5 \%\end{array}$

(1)

$66.0 \quad 5.9 \% \quad 25.8 \%$

$\%$ to gas

$\%$ to liquids

$\%$ to solids

$5.7 \%$

3.8

$1.6 \%$

$32.8 \%$

$1.3 \%$

$19.4 \%$

3.1

46.1

$0.0 \%$

$3.3 \%$

7.9

$0.0 \%$

$2.5 \%$

6.0

$3.3 \%$

$0.8 \%$

2.0

$0.0 \%$

0.0

$0.8 \%$

2.0

$0.0 \%$

36.7

$15.5 \%$

1.1

$0.4 \%$

0.0

$-71.9 \%$

733.2

14.7

43.7

27.8

$-4.6 \%$

$-10.5 \%$

$18.4 \%$

$1.6 \%$

$33.3 \%$

$1.3 \%$

$19.7 \%$

$0.0 \%$

$3.4 \%$

$0.0 \%$

$2.5 \%$

$3.4 \%$

$0.8 \%$

$0.0 \%$

$0.8 \%$

$0.0 \%$

$15.7 \%$

$0.5 \%$

$-71.9 \%$

$0.2 \%$

$-10.4 \%$

$18.7 \%$

$1258.1 \quad-15.1 \% \quad 73.7 \%$

1595.9

1324.1

$83.0 \%$

$-42.7 \%$

$100.0 \%$

moles $\mathrm{O} 2 / \mathrm{CH} 4$ in

2.2

$89.3 \%$

$5.0 \%$ 
P038

Temp C

625

Press, psig

44

feedrate, $/ \mathrm{b} / \mathrm{hr}$

runtime, hrs

$\% \mathrm{CaO} / \mathrm{sand}$

100

8

5

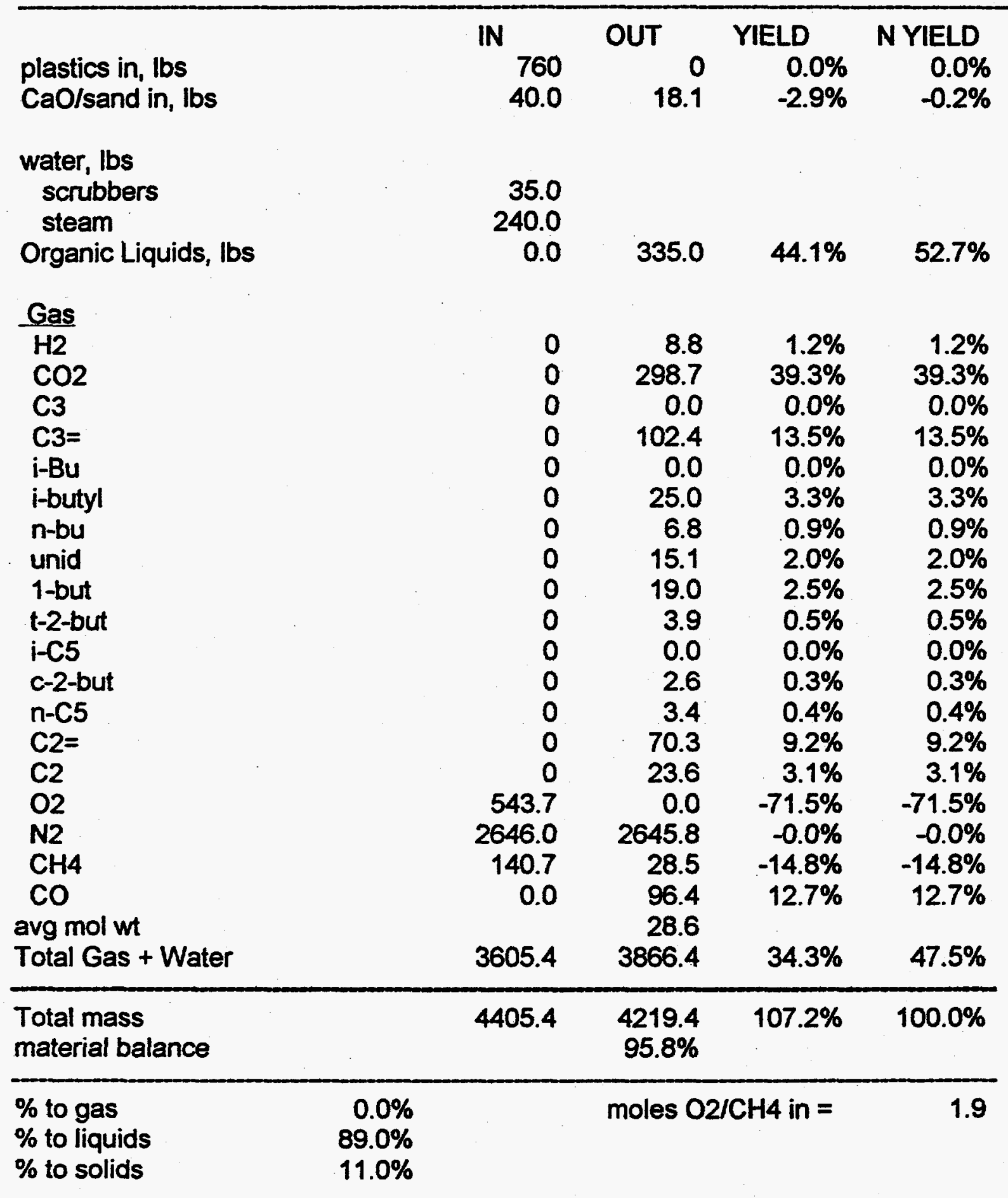


P041

Temp C

627

Press, psig

35

feedrate, Ib/hr

100

runtime, hrs

2

$\% \mathrm{CaO} /$ sand

15

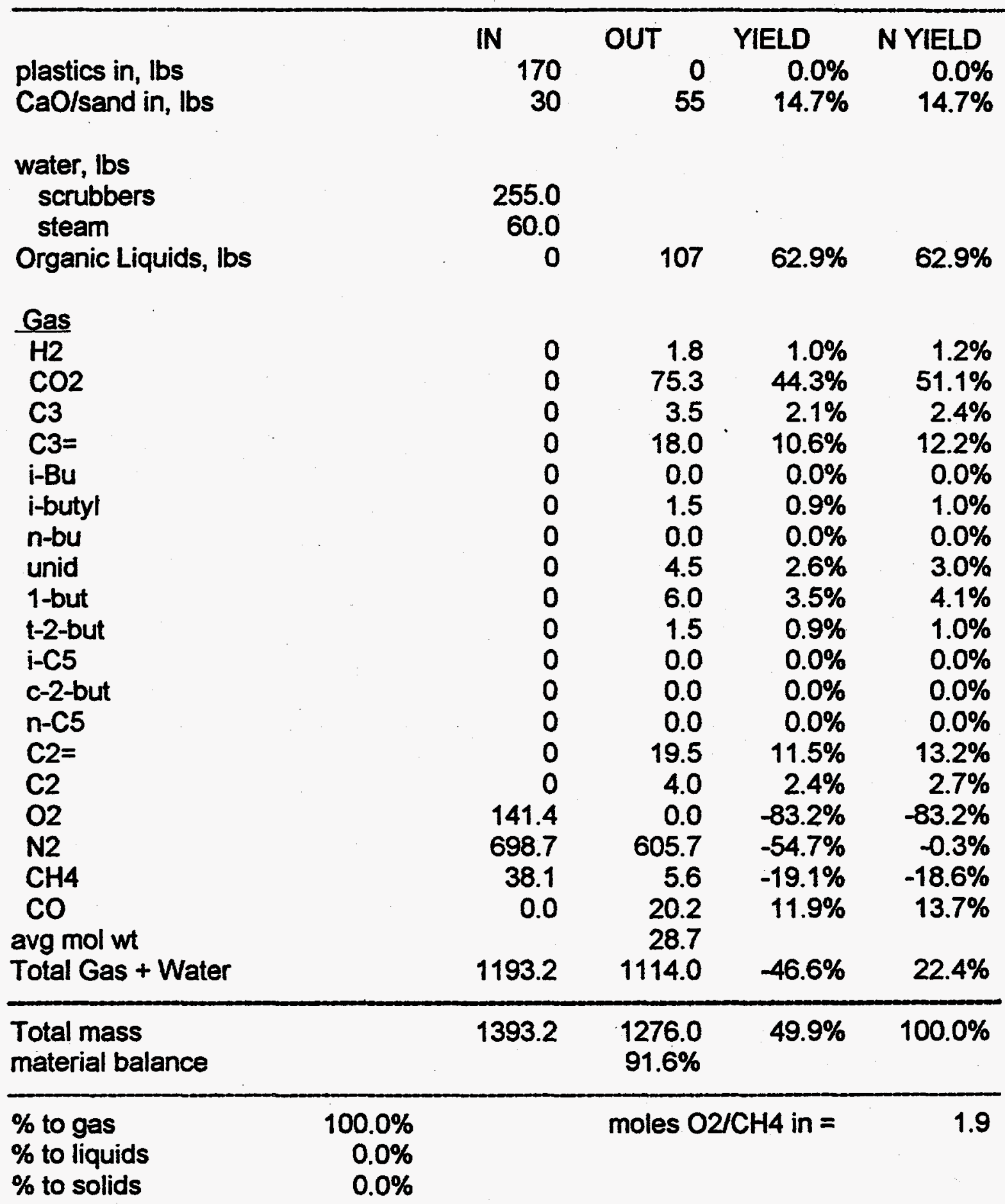


Temp C

P042

Press, psig

feedrate, $\mathrm{lb} / \mathrm{hr}$

runtime, hrs

\% CaOlsand
625

15

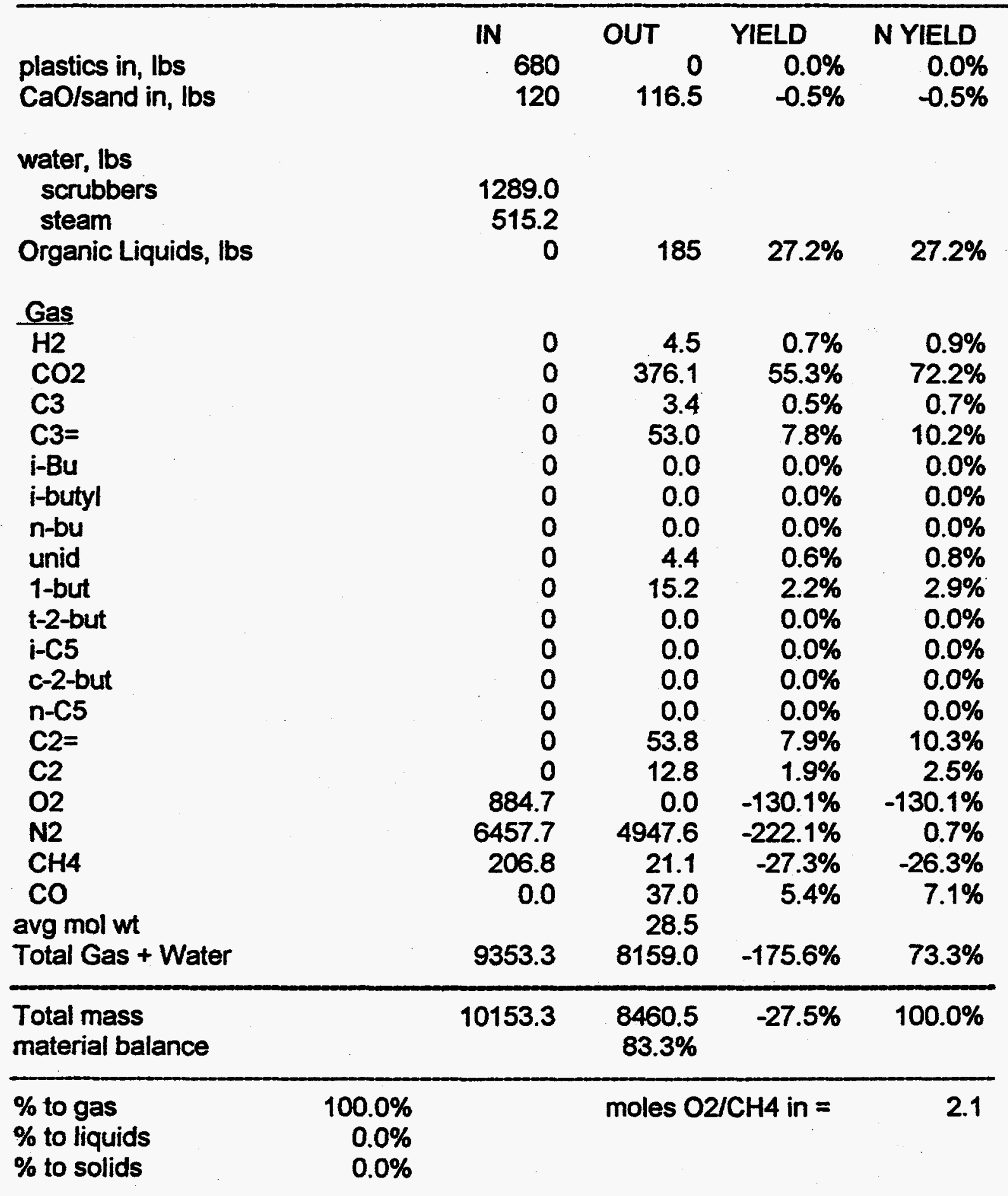


Temp C

Press, psig

feedrate, $\mathrm{lb} / \mathrm{hr}$

runtime, hrs

$\% \mathrm{CaO} / \mathrm{sand}$
IN

plastics in, lbs

$\mathrm{CaO} / \mathrm{sand}$ in, Ibs

water, lbs scrubbers

steam

Organic Liquids, Ibs
508.2

38.2

160.0

0.0

0.0

0.0

0.0

0.0

0.0

0.0

0.0

0.0

0.0

0.0

0.0

0.0

0.0 .

0.0

0.0

0.0

469.3

3066.5

84.9

0.0

$\mathrm{CO}$

avg mol wt

Total Gas + Water

\section{OUT}

0.0

57.0

YIELD

$0.0 \%$

$3.7 \%$

N YIELD

$0.0 \%$

$3.7 \%$
68.3

8
590

\section{(1)}

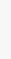

\begin{tabular}{lrrrr} 
Gas & & & & \\
$\mathrm{H} 2$ & 0.0 & 0.5 & $0.1 \%$ & $0.1 \%$ \\
$\mathrm{CO} 2$ & 0.0 & 332.5 & $65.4 \%$ & $71.2 \%$ \\
$\mathrm{C} 3$ & 0.0 & 4.5 & $0.9 \%$ & $1.0 \%$ \\
$\mathrm{C} 3=$ & 0.0 & 29.3 & $5.8 \%$ & $6.3 \%$ \\
$\mathrm{i}-\mathrm{Bu}$ & 0.0 & 0.0 & $0.0 \%$ & $0.0 \%$ \\
i-butyl & 0.0 & 0.0 & $0.0 \%$ & $0.0 \%$ \\
$\mathrm{n}$-bu & 0.0 & 0.0 & $0.0 \%$ & $0.0 \%$ \\
unid & 0.0 & 0.0 & $0.0 \%$ & $0.0 \%$ \\
1-but & 0.0 & 8.8 & $1.7 \%$ & $1.9 \%$ \\
t-2-but & 0.0 & 0.0 & $0.0 \%$ & $0.0 \%$ \\
i-C5 & 0.0 & 0.0 & $0.0 \%$ & $0.0 \%$ \\
C-2-but & 0.0 & 0.0 & $0.0 \%$ & $0.0 \%$ \\
n-C5 & 0.0 & 0.0 & $0.0 \%$ & $0.0 \%$ \\
C2= & 0.0 & 36.5 & $7.2 \%$ & $7.8 \%$ \\
C2 & 0.0 & 7.1 & $1.4 \%$ & $1.5 \%$ \\
O2 & 469.3 & 0.0 & $-92.3 \%$ & $-92.3 \%$ \\
N2 & 3066.5 & 2819.7 & $-48.6 \%$ & $-0.0 \%$ \\
CH4 & 84.9 & 11.3 & $-14.5 \%$ & $-14.3 \%$ \\
CO & 0.0 & 19.5 & $3.8 \%$ & $4.2 \%$ \\
avg mol wt & & 29.1 & & \\
Total Gas + Water & 3780.6 & 3617.7 & $-32.1 \%$ & $78.7 \%$ \\
\hline Total mass & 4327.0 & 3724.7 & $18.5 \%$ & $100.0 \%$ \\
material balance & & $86.1 \%$ & &
\end{tabular}

$\%$ to gas

$\%$ to liquids

$\%$ to solids
$47.5 \%$

$52.5 \%$

$0.0 \%$ moles $\mathrm{O} 2 / \mathrm{CH} 4$ in $=$

2.8 
APPENDIX D

SEM ANALYSIS OF PO39 BED MATERIAL 
MATURAT MATERIALS AKAIYTICAT RESEARCH IABORATORY

SAMPLE AMAIYSIS REOUEST

$05 / 04 / 94$

FUND NO: 4717

PI: AULICH

Date submitted: $05 / 04 / 94$

Project: PLASTICS DECOMPOSITION

Fample Description=

DISTRIBUTOR PLATE BUBBLE CAP DEPOSIT-POSSIBLY CONTAINING CHLORIDE

Sample Type: DEPOSIT

Sample Source: PILOT SCALE

Collection Device: REACTOR PLUG

Deposit Location: DISTRIBUTOR PLATE

Coal Name:

Coal Seam:

Coal Mine:

other coal Info:

Comments
MMARL NO:

6686
Company: APC

Contact: 

Label: 6679b.F6.5125.X51.Y153

$k V: 15.0$ Cumment: $0.0000 \mathrm{nA}$ Take_off: 40.1 Live Time: 25 Stage: $X=15.4919 \quad Y=-30.1190 \quad Z=32.1609 \quad F=-0.00 \quad B=0.02 \quad T=-0.00$ Beam: $X=25.6414 \mathrm{M}(3072) \quad Y=2.003 u M(2128)$

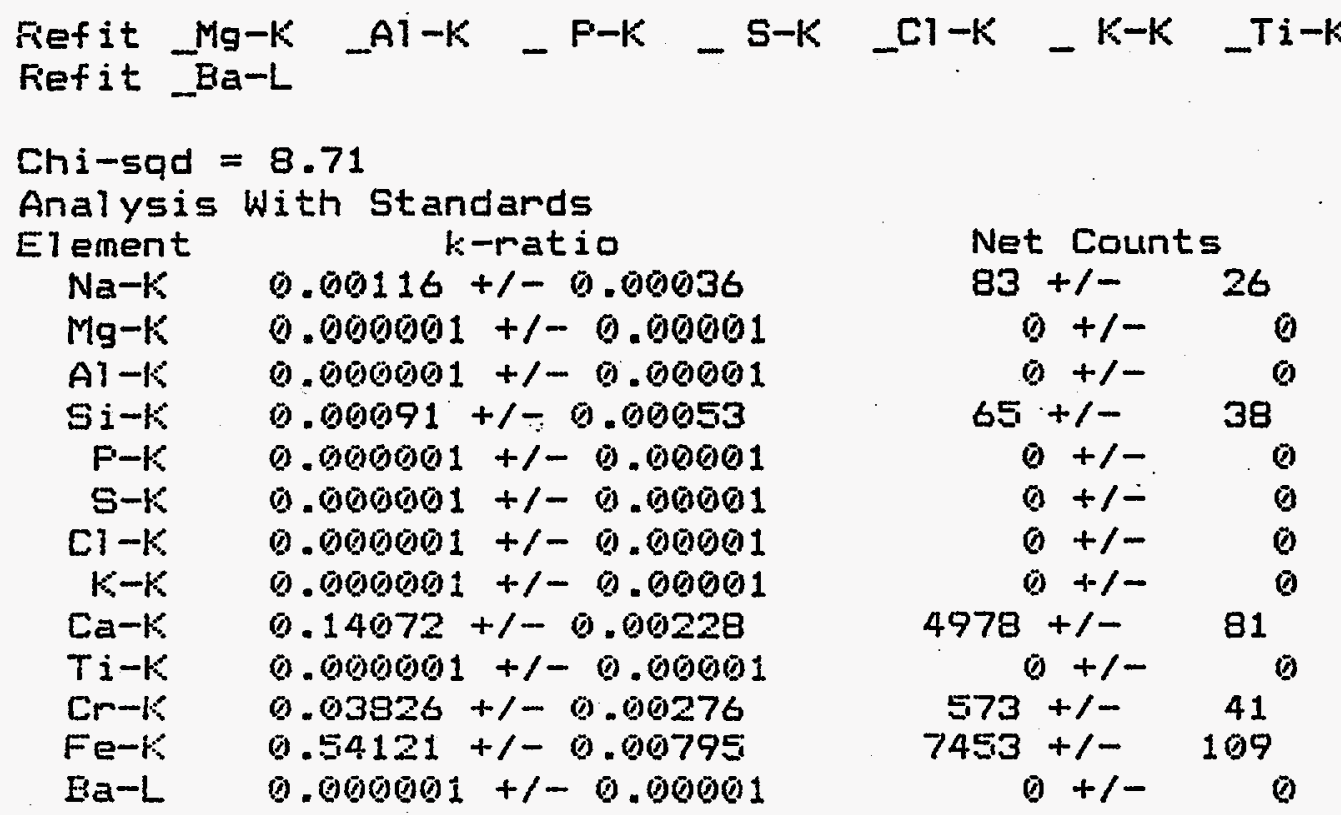

ZAF Correction $15.00 \mathrm{kV} 40.15$ deg No. of Iterations $=3$

\begin{tabular}{|c|c|c|c|c|c|c|c|c|}
\hline $\begin{array}{l}\text { ement } \\
\text { Na-K } \\
M g-K \\
A 1-K \\
S i-K \\
F-K \\
S-K \\
C 1-K \\
K-K \\
C a-K \\
T i-K \\
C r-K \\
F e-K \\
\text { Ea-L } \\
D-K \\
\text { Total }\end{array}$ & $\begin{array}{l}\text { 1.ratio } \\
0.00116 \\
0.00000 \\
0.00000 \\
0.00091 \\
0.00000 \\
0.00000 \\
0.00000 \\
0.00000 \\
0.14072 \\
0.00000 \\
0.03226 \\
0.54121 \\
0.00000 \\
-.0-\end{array}$ & $\begin{array}{c}z \\
0.979 \\
0.956 \\
0.985 \\
0.958 \\
0.991 \\
0.966 \\
1.010 \\
1.005 \\
0.981 \\
1.077 \\
1.081 \\
1.082 \\
1.314 \\
0.915\end{array}$ & $\begin{array}{c}A \\
3.137 \\
2.243- \\
1.762 \\
1.471 \\
1.302 \\
1.190 \\
1.123 \\
1.048 \\
1.028 \\
1.036 \\
1.015 \\
1.008 \\
0.984 \\
2.240\end{array}$ & $\begin{array}{c}F \\
1.000 \\
1.000 \\
0.999 \\
0.998 \\
0.997 . \\
0.994 \\
0.989 \\
0.967 \\
0.979 \\
0.953 \\
0.900 \\
1.000 \\
0.955 \\
0.998\end{array}$ & $\begin{array}{r}\text { Aton \% } \\
0.44 \\
0.004 \\
0.003 \\
0.13 \\
0.008 \\
0.004 \\
0.0023 \\
0.0019 \\
9.76 \\
0.0064 \\
2.05 \\
29.73 \\
0.0035 \\
57.90\end{array}$ & $\begin{array}{r}\text { Wt \% } \\
0.36 \\
0.000 \\
0.000 \\
0.13 \\
0.000 \\
0.000 \\
0.000 \\
0.000 \\
13.08 \\
0.000 \\
3.78 \\
59.00 \\
0.000 \\
32.92 \\
110.06\end{array}$ & $\begin{array}{l}\text { Formul a } \\
\text { Na20 } \\
\text { MgO } \\
\text { A1 } 203 \\
5 i 02 \\
\text { P205 } \\
\text { S } 03 \\
\text { C10 } \\
\text { K20 } \\
\text { CaO } \\
\text { Ti02 } \\
\text { Cr203 } \\
\text { Fe203 } \\
\text { BaO } \\
--\end{array}$ & $\begin{array}{c}\text { Compound\% } \\
0.48 \\
0.000 \\
0.000 \\
0.27 \\
0.000 \\
0.000 \\
0.000 \\
0.000 \\
19.43 \\
0.000 \\
5.53 \\
84.35 \\
0.000 \\
-0.06 \%\end{array}$ \\
\hline
\end{tabular}

\begin{tabular}{|c|c|c|c|c|c|}
\hline $\begin{array}{l}\text { Na- } 0.1204 \\
P-0.0000 \\
\mathrm{Ca}-2.6981 \\
\mathrm{Ea}-0.00000\end{array}$ & $\begin{array}{l}\mathrm{Mg}- \\
\mathrm{S}-- \\
\mathrm{T}_{\mathrm{i}-} \\
\mathrm{O}-\mathrm{I}\end{array}$ & $\begin{array}{l}0.0001 \\
0.0000 \\
0.0000 \\
16.0000\end{array}$ & $\begin{array}{l}\mathrm{Al}-- \\
\mathrm{Cl}-- \\
\mathrm{Cr}-\end{array}$ & $\begin{array}{l}0.0001 \\
0.0000 \\
0.5654\end{array}$ & $\begin{array}{l}S i- \\
K-- \\
\text { Fe- }\end{array}$ \\
\hline
\end{tabular}


LEbel : 6679 b.F6.5125.X51.Y153

CV: 15i.0 Cumment: 0.0000nA Tal:e off: 40.1 Live Time: 25

Stage: $X= \pm 5.9488 \quad Y=-29.8898 \quad Z=32 . i 609 \quad F=-0.00 \quad B=0.02 \quad T=-0.00$

EEam: $X=3.015$ UM $\{2 \div 76) \quad Y=0.000 \mathrm{uM}(1376)$

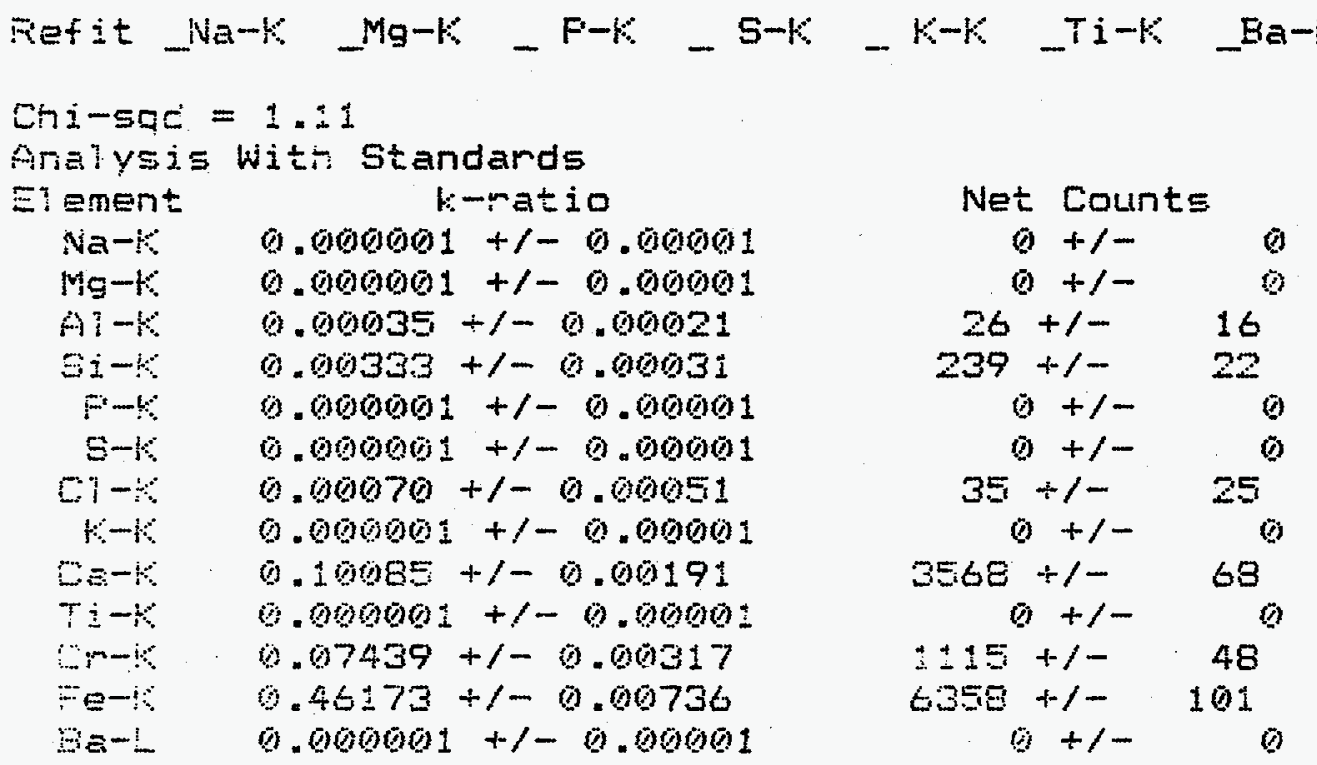

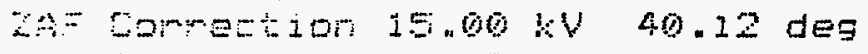

ve. $\div$ terations $=3$

\begin{tabular}{|c|c|c|c|c|c|c|c|c|}
\hline$\because \rightarrow n \in$ & $\therefore-m=a$ & 2 & $A$ & $\bar{F}$ & Atom \% & hit $\%$ & Formul a & Compolind\% \\
\hline$A n-6$ & o. moones & 6.978 & 3.122 & \pm .000 & 0.006 & 0.000 & $\mathrm{Na} 2 \mathrm{O}$ & 0.000 \\
\hline 89 & 1.00000 & 6.954 & 2.244 & 1.000 & 0.004 & 0.000 & MgO & 0.000 \\
\hline$A:-$ & 0.00035 & 0.984 & 1.762 & 0.999 & 0.07 & 0.06 & A1 203 & $0.1 i$ \\
\hline $5-6$ & 1.0653 & 0.750 & 1.475 & 0.999 & 0.53 & 0.47 & SiOZ & 1.00 \\
\hline$=-1$. & 0.00000 & 0.989 & 1.304 & 0.997 & 0.000 & 0.000 & F20E & 0.000 \\
\hline$B-\alpha$ & 0.60000 & 0.965 & 1.192 & 0.995 & 0.004 & 0.000 & 503 & 0.000 \\
\hline$=-4$ & 0.00070 & 1.009 & 1.125 & 0.990 & 0.07 & 0.08 & 010 & 0.11 \\
\hline$\therefore-6$ & 0.00000 & $i .004$ & 1.049 & 0.970 & 0.0021 & 0.000 & 120 & 0.000 \\
\hline $3 e-5$ & 0.10086 & 0.979 & 1.028 & 0.977 & 7.84 & 9.93 & $\mathrm{CaO}$ & 13.90 \\
\hline$=-\infty$ & 0.00000 & 1.075 & 1.031 & 0.948 & 0.0052 & 0.000 & TiOZ & 0.000 \\
\hline $2-3$ & 0.07439 & 1.079 & i.013 & 0.906 & 4.47 & 7.37 & $C-203$ & 10.77 \\
\hline$F=-6$ & 6.46173 & 1.080 & 1.010 & 1.000 & 28.49 & 50.38 & Fezo3 & 72.03 \\
\hline Ea- & 0.00000 & 1.312 & 0.980 & 0.953 & 0.0025 & 0.000 & EaO & 0.000 \\
\hline $\begin{array}{l}-r \\
\text { Tota: }\end{array}$ & - & 0.914 & 2.074 & 0.958 & 58.52 & $\begin{array}{l}29.64 \\
97.93\end{array}$ & -- & 97.73 \\
\hline
\end{tabular}

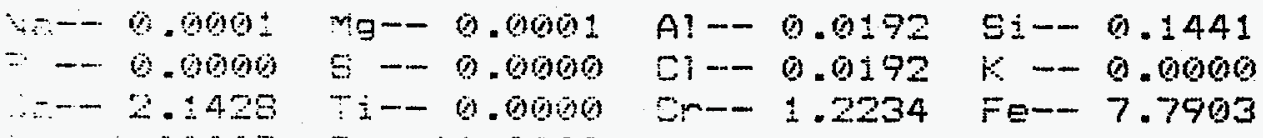


Labei: $66796 . F 6.5225 . X 51 . Y 153$

HV: 15.0 Cumment: 0.0000nA Take off: 40.2 Live Time: 25

Stage: $X=16.9344 \quad Y=-30.2348 \quad Z=32.1609 \quad K=-0.00 \quad E=0.02 \quad T=-0.00$

Eeam: $X=0.000$ uty (1552) $Y=0.000 u M(272)$

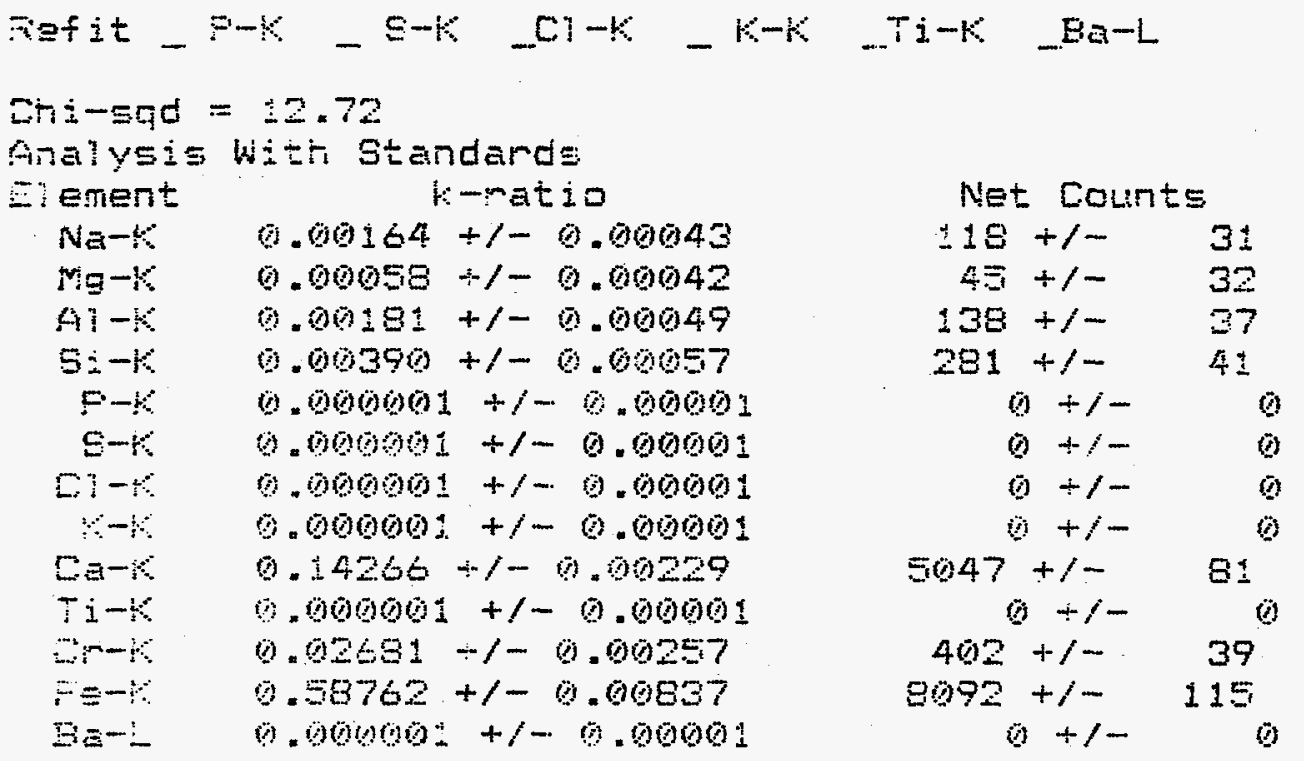

ZAF

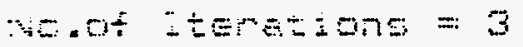

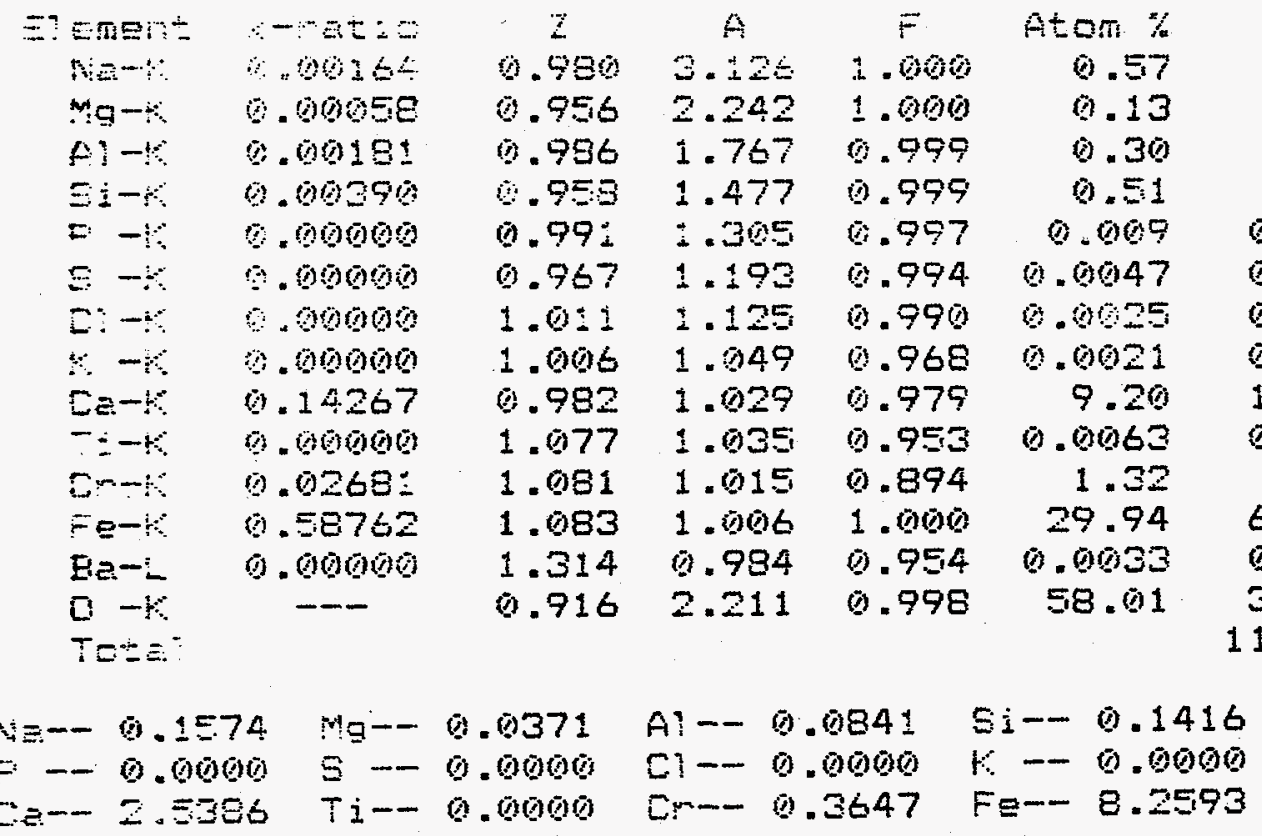

$\equiv \equiv-0.00003$ a -16.0000 


\section{APPENDIX E}

\section{ANALYSIS OF PO42 LIQUIDS}


Preliminary Analysis of P042 Sieve Tower Residue, 6-9-94

Ted Aulich, 6-10-94

\section{Analyses}

1) Preliminary THF solubility analysis--50\% THF solubles

2) Extraction with $0.1 \mathrm{M} \mathrm{NaOH}-42 \%$ base solubles

Acidification of solubles--3\% organic acids

Possibility of chlorine in base extract?

3) TGA Results--32\% moisture, $48 \%$ volatile matter, $5 \%$ fixed carbon, $15 \%$ ash

\section{Interpretations}

1) Comparison of TGA moisture (32\%) with base extraction-- $42 \%$ minus $3 \%$ organic acids equals 39\%; if we have some chlorine in the water, our water value is lower than $39 \%$, which gets us closer to the TGA $32 \%$.

2) If, based on $\mathrm{TGA}$, we assume $8 \% \mathrm{CO}_{2}$ (from $\mathrm{CaCO}_{3}$--volatiles emitted starting at about $796^{\circ} \mathrm{C}$ ), this equates to about $13 \% \mathrm{CaO}$; we have $15 \%$ ash based on TGA. Presence of $\mathrm{CaCl}_{2}$ ?

3) At temperatures below about $400^{\circ} \mathrm{C}$, we are volatilizing individual compounds; at temperatures of about 300 to $600^{\circ} \mathrm{C}$, we are decomposing material. The TGA shows that we probably have both volatilization and decomposition happening (volatiles coming off between 200 and $650^{\circ} \mathrm{C}$ ), which means that some of the fixed carbon we see is probably generated during the TGA itself. This means that the $5 \%$ referred to as fixed carbon (material that is involatile up to $950^{\circ} \mathrm{C}$ in an inert atmosphere, but is combustible at $750^{\circ} \mathrm{C}$ ) may be both process- and analysis-derived material.

4) If we subtract $8 \% \mathrm{CO}_{2}$, we are left with $40 \%$ volatiles, which probably consist of partially reacted polymer material. Of this $40 \%$, about $11-18 \%$ is THF-soluble material (depending on which moisture value-TGA or base extraction--we use).

5) The fact that we have very little material volatilizing between $100^{\circ} \mathrm{C}$ and about $250^{\circ} \mathrm{C}$ indicates the presence of very little oil in the sample. This supports the TGA moisture value as being representative of water, as opposed to a combination of water and organics that boil at about $100^{\circ} \mathrm{C}$.

\section{Preliminary Conclusions}

1) The volatile organic portion (about $40 \%$ ) of the sample is comprised primarily of partially reacted polymer material.

2) The sample contains about $3 \%$ organic acids.

3) The sample contains a small amount (probably less than $5 \%$ ) of highly carbonized (coked) material. 
APPENDIX F

TGA GRAPHS OF PDU SOLIDS 

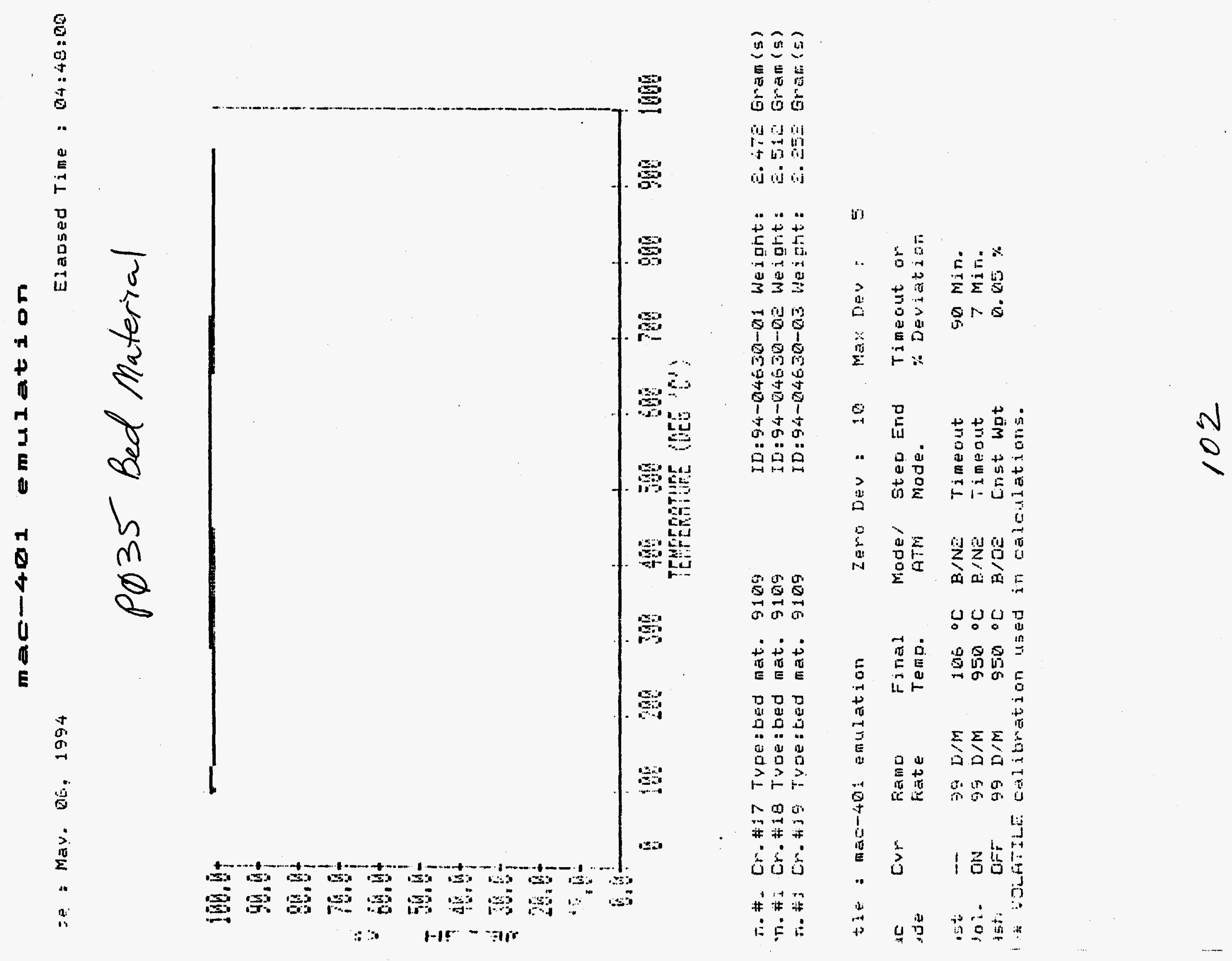
$m a c-401$ muIat ion

at- : May. Q6e, 1954

Elansed Time : 04:E7:00

P035 Secondany Cyclone

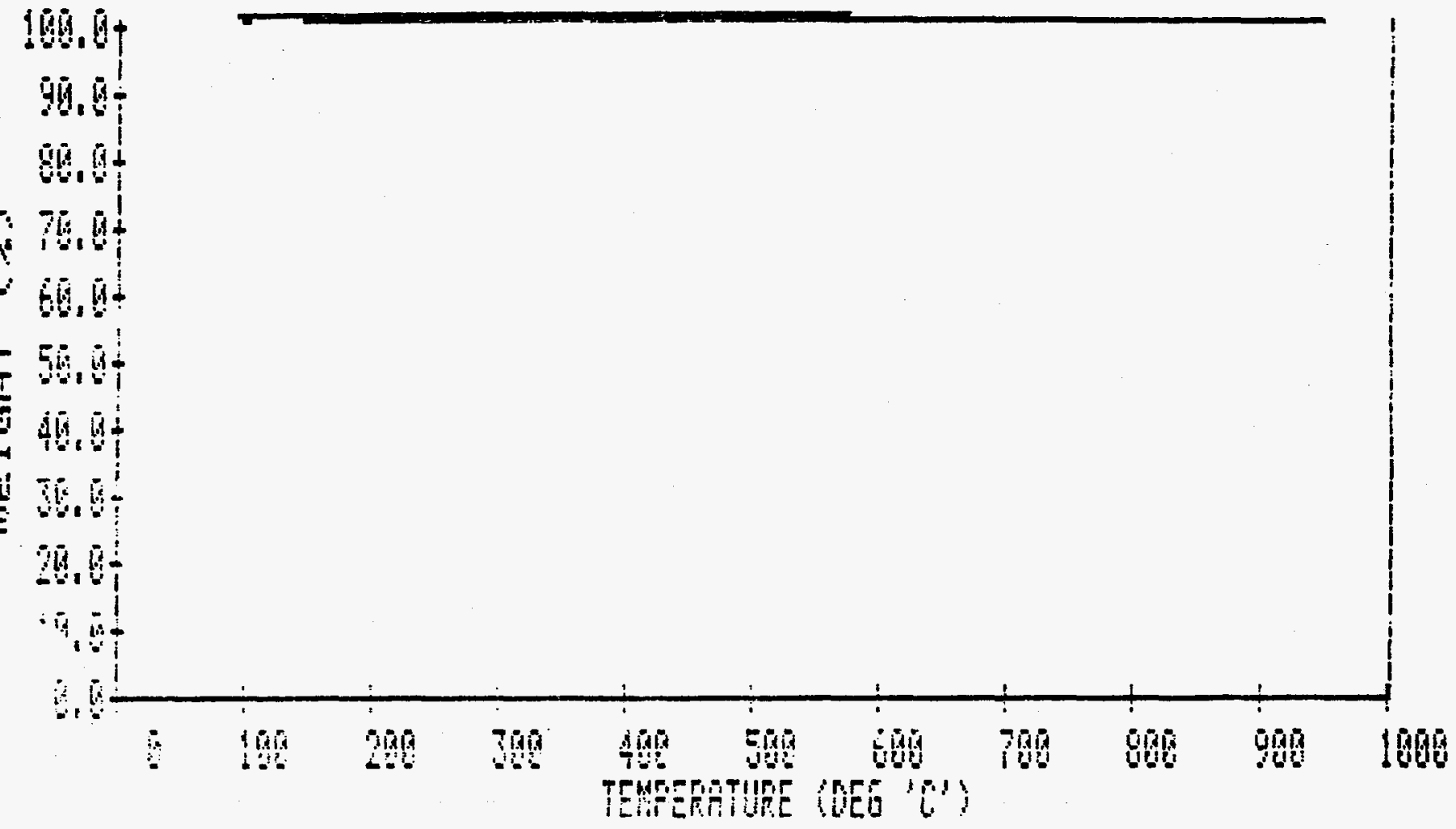

T. \# Cr. \# 4. Turessec.cyclane 9110

ID: 94-Q4E4Q-Q1. Weight:

E. 546 Gran (s)

ri. \# Cr. \# 5 TYoessec.cvelone $91 i Q$ ID: $94-04440-0$ - We inrit:

E. $47 E$ Gran (s)

r. \#E Cr. \#

ID: 94-Q4E4Q-Q3 Weight:

E. E(t) Gramis

tis : mac-4bi emulation

$\because$ Evr Rant

is

$\therefore \mathrm{t} \quad-\cdots$

a. ON

ist OFF

$\rightarrow$ UDiAT"ito

\section{zeroo}

Final. Temo.

Mode/ Stat End

ATM Mode.

E/NE Timeout

B/NE

B/OE
Timeout

Cnst wot
Max Dev :' $=$

Timeout or

\% Deviezion

90 Min.

7 Min.

Q. $05 \%$ 
$m a c-4 m 1$ muIation

if : Mav. 06, 1994

Elansed Time : 04:E7:00

P\$36 Bedmaterial

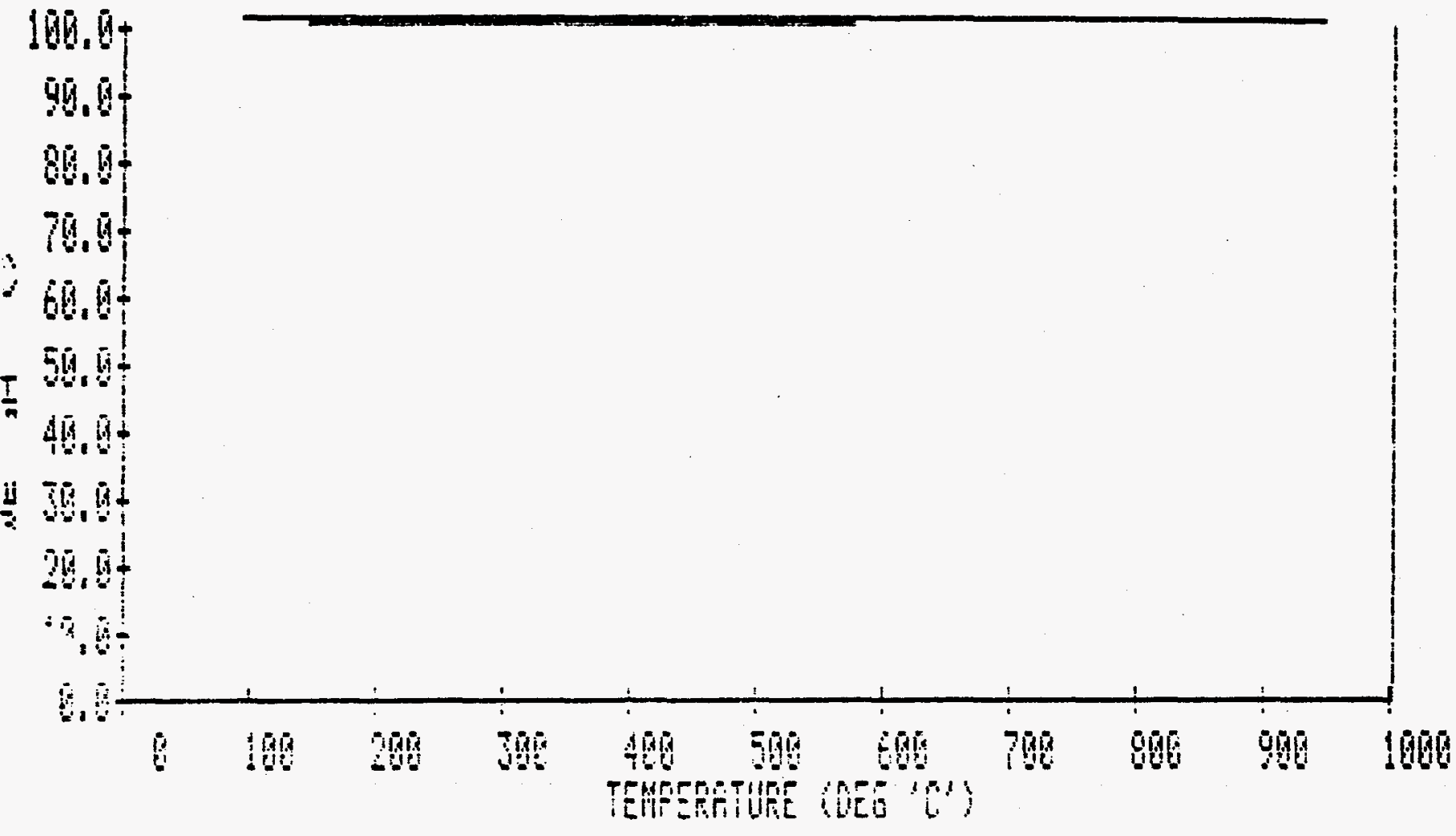

T..

r. HE Cr. \# 5 Tvoe:bed mat. 9111

r. \#E Cr. \#10 Tyoe:bed mat. Q111 1j: 94-Q4EEQ-Q1 Wejoht: ID: $94-04050-n=$ Weiotit:

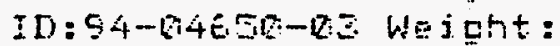

ㄹ. 355 Gind (s)

E. Q 23 Gran(s)

‥ 콩 Eram (s)
tie: $m a c-401$ emslation
Lero DeV : 10
$\operatorname{Max}$ Dev : 5

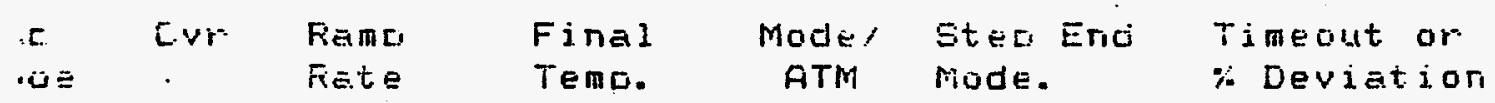

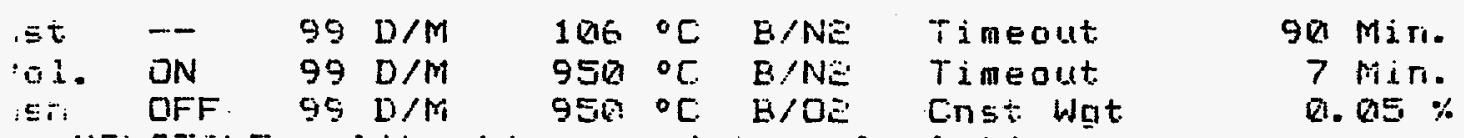

* VOLATILE Ealibration used ir Ealouiations. 
Sample: P039: B.M. AGGLOM.ABOVE TC $\$ 305$ S128: $\quad 55.5683 \mathrm{mg}$

TGA $\quad \begin{aligned} & \text { File: A: } 940104.001 \\ & \text { Operator: KULAS }\end{aligned}$

Method: PROX

Comment: PROX.UPON AGGLOM.OF P039'X BED MATER. ABOVE TC305; 4717; 940104

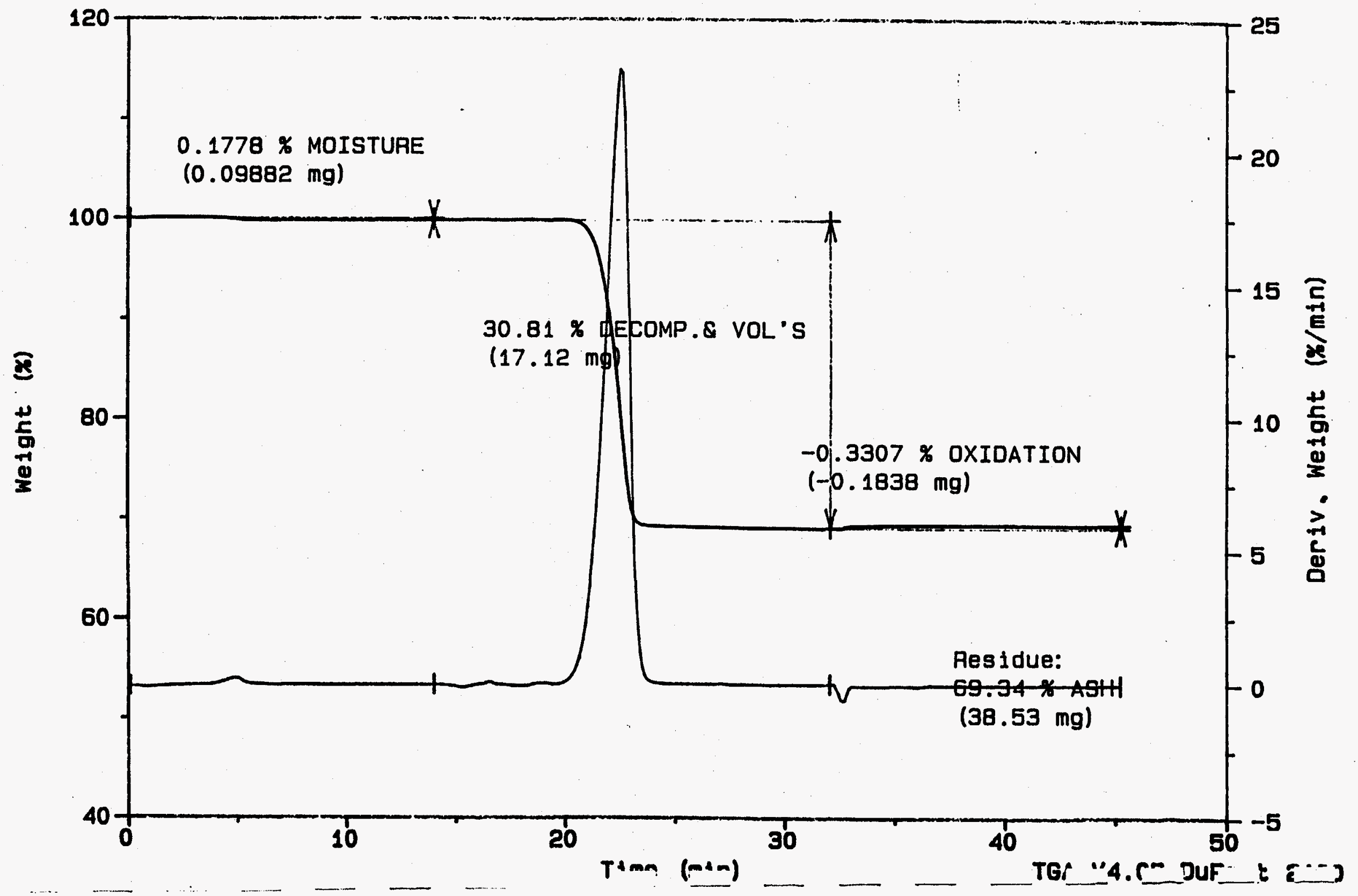


Samp 1e: P039: B.M. AGGLOM.DIST.PLATE S1ze: $\quad 48.5898 \mathrm{mg}$

Method: PROX

Comment: PROX.UPON AGGLOM.ON DISTRIBUTOR PLATE
F11e: A: 940105.001

Operator: KULAS

Run Date: 14-Apr-94 02: 09 A 4717:940105

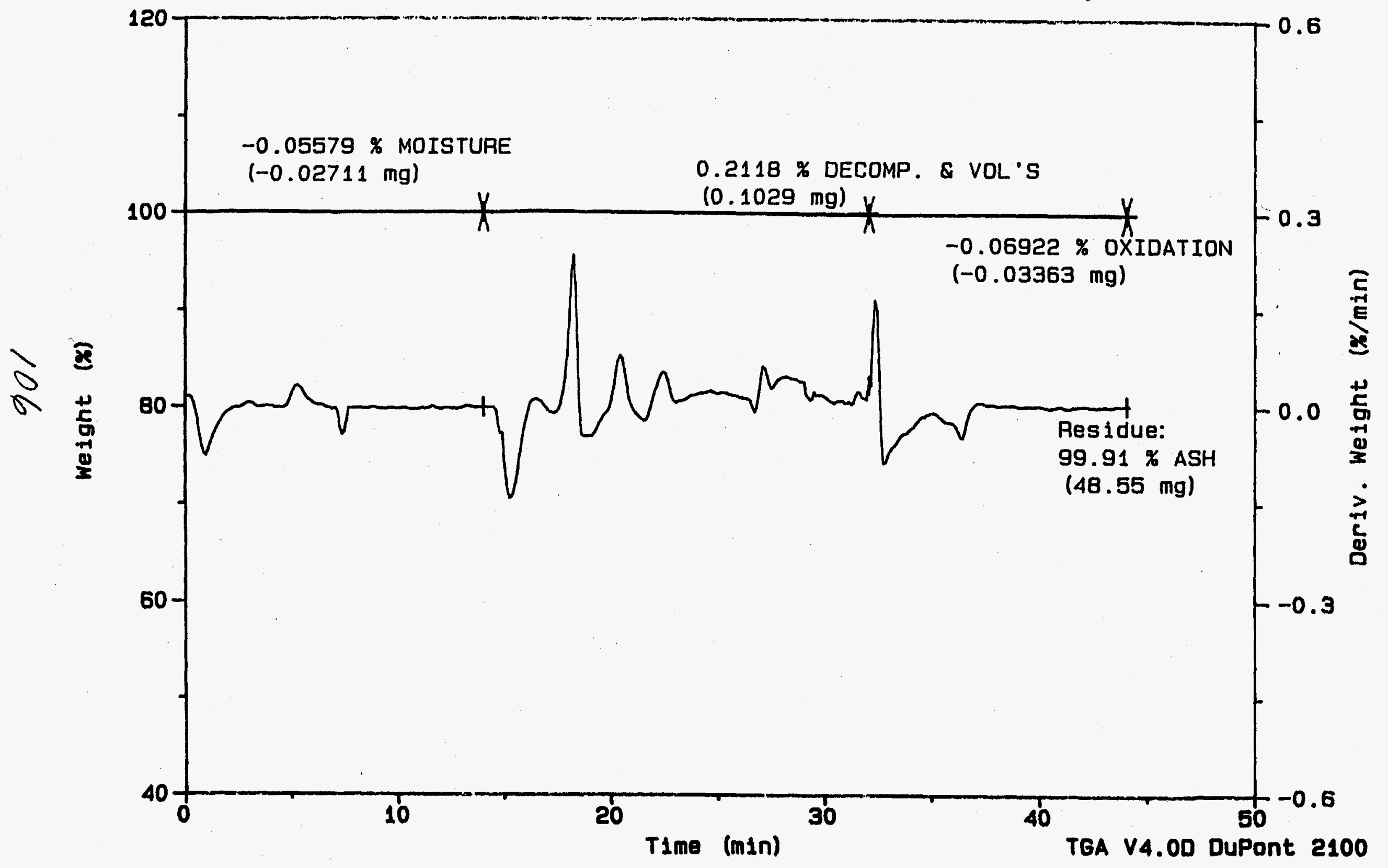


Samp 1e: P039: B.M. AGGLOM.AT TC305

S1ze: $54.1099 \mathrm{mg}$

Method: PROX

Comment: PAOX.UPON AGGLOM.AT TC305

TGA
F11e: A: 940106.001

Operator: KULAS

Run Date: 14-Apr-94 03: 22 A) 4717: 940106

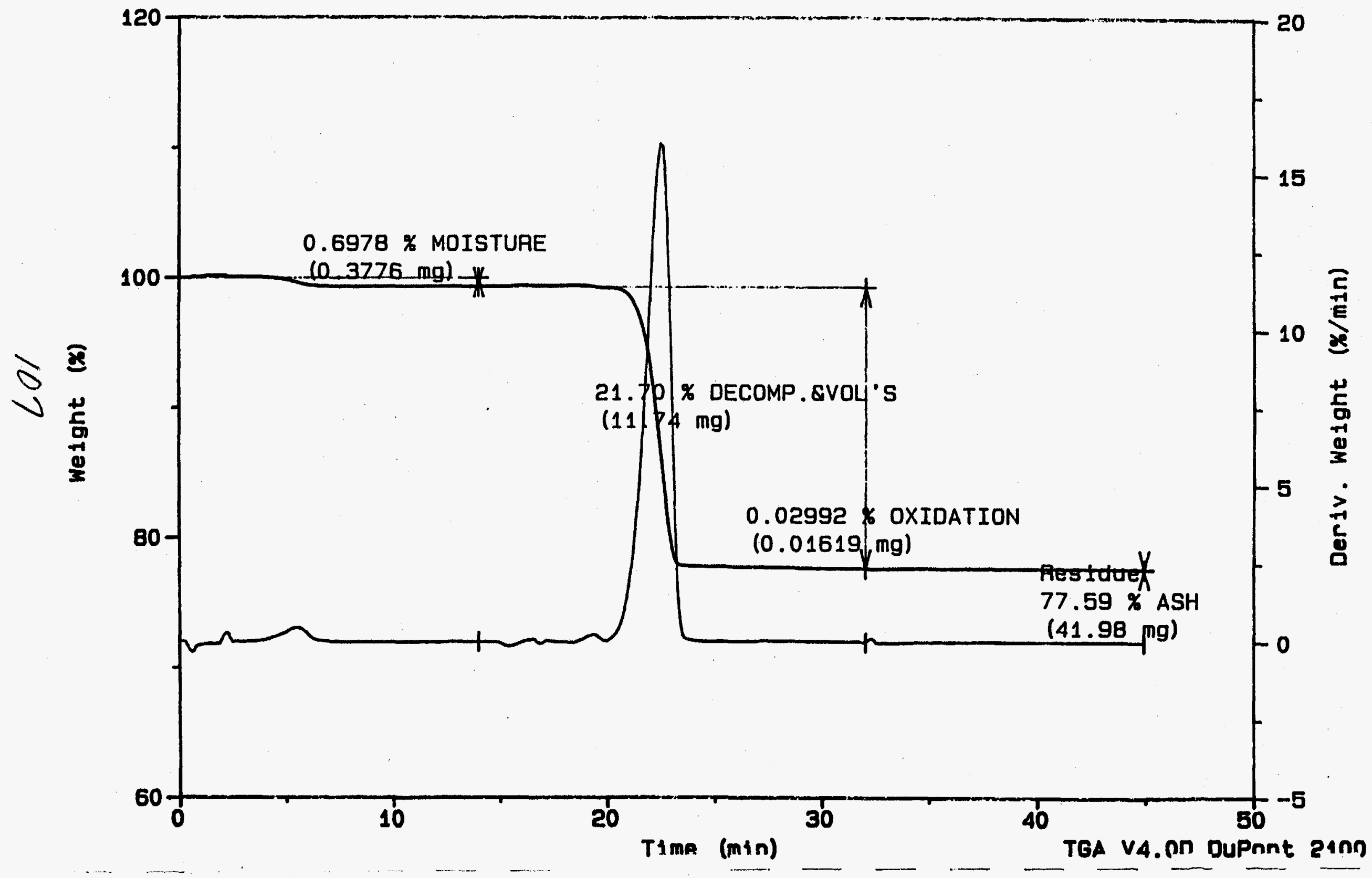


Semple: P039: B.M. AGG.AR TC304: POST-AUN $T G A$
S1ze: $48.2420 \mathrm{mg}$ Method: PROX

Comment: PROX.UPON AGGLOM.AT TC3O4

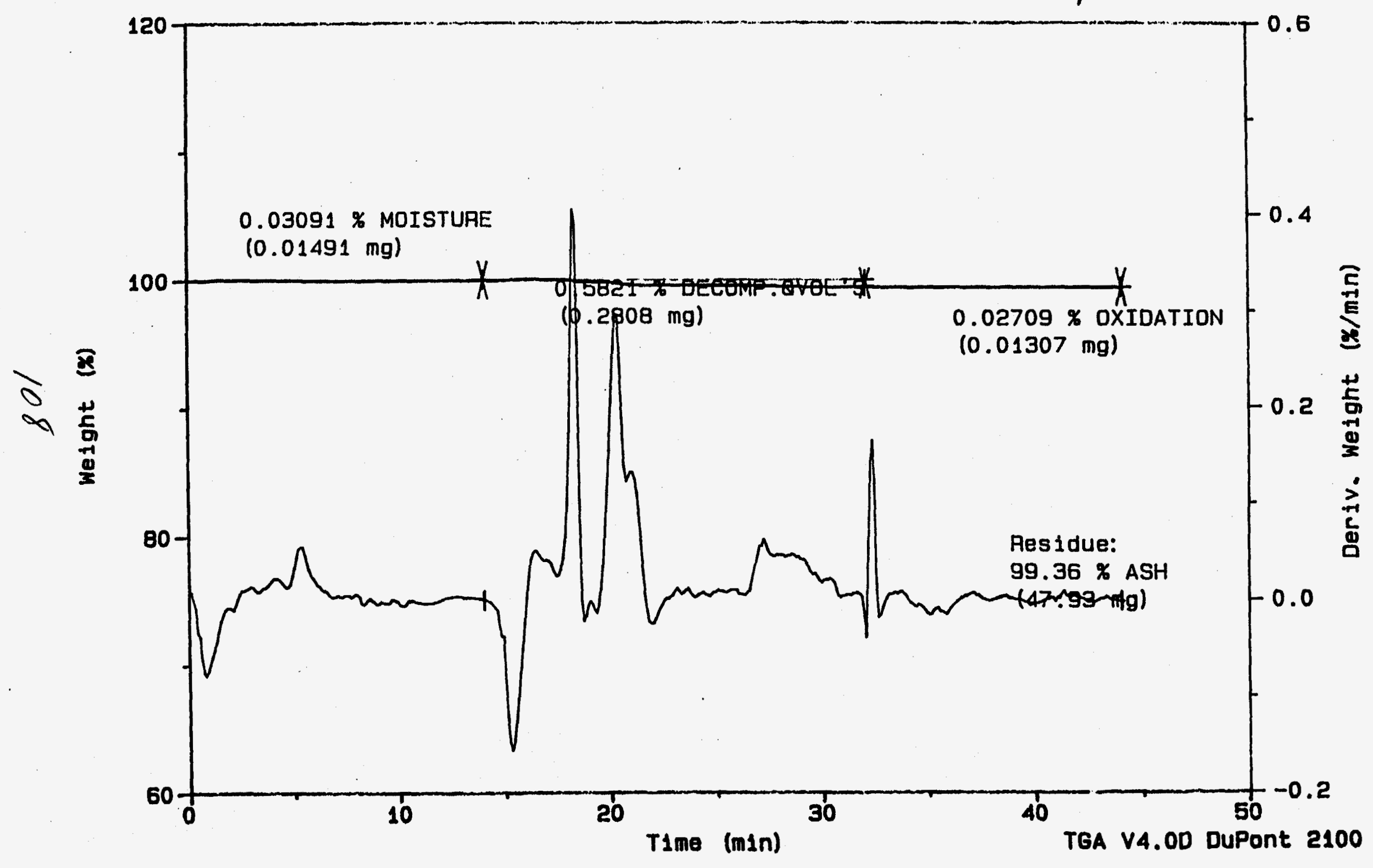

F11e: A: 940107.001 Operator: KULAS

Run Date: 14-Apr-94 20: 53 A*4717: 940109 


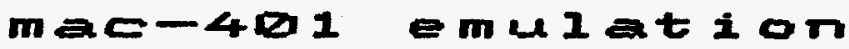

ite = MaY. 05. 1954

Ela0ses Time: $04: 43: 00$

P\$39 Secondary Cyclone

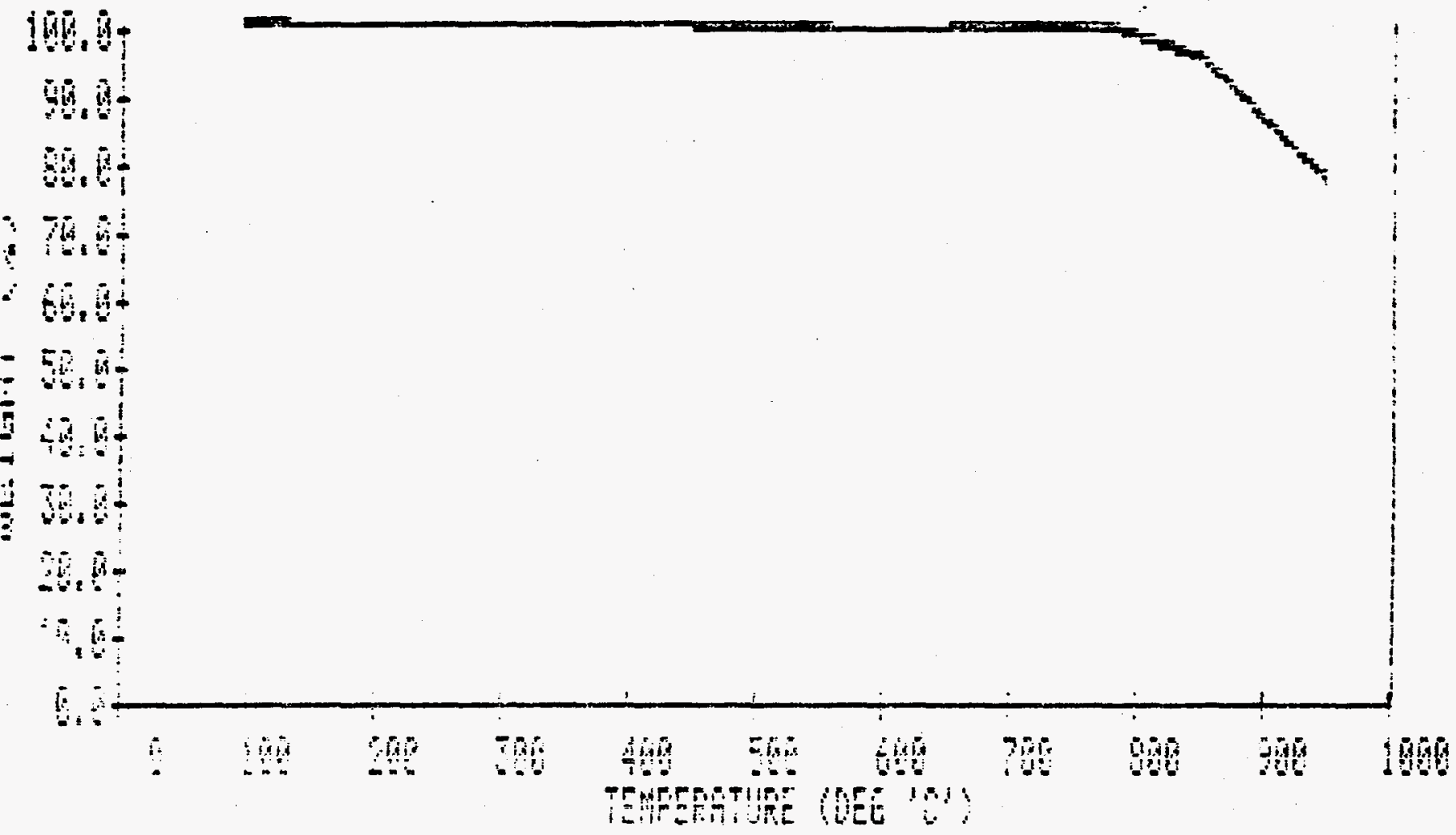

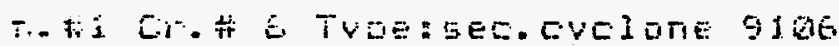

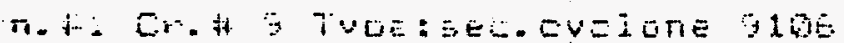

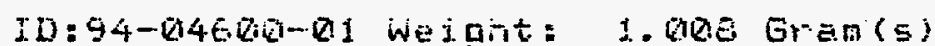
ID: 94-6468R-oz Weight: i. 077 Gramis:

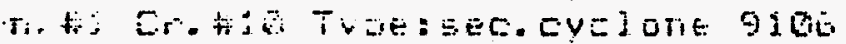

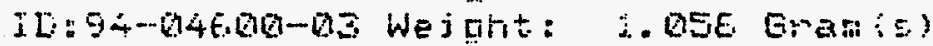

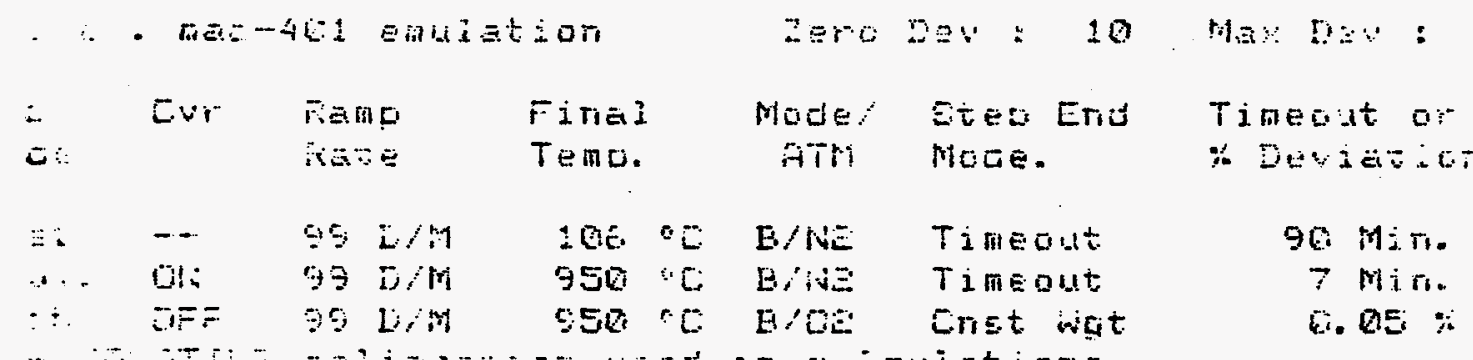

$\because \quad \therefore$ ritila 


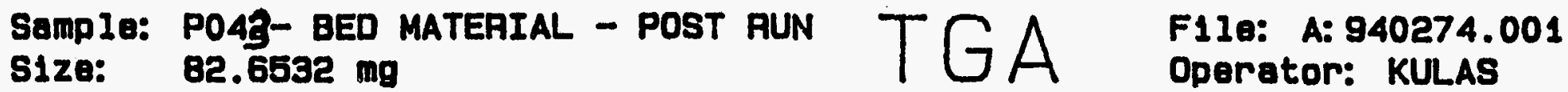
S1ze: $\quad 82.6532 \mathrm{mg}$

Method: PROX

F11e: A: 940274.

Run Date: 10-Jun-94 04: 13

Comment: PROXIMATE ANALYSIS SHARP'S PO43 BED MATERIAL; POST RUN: A\$4717

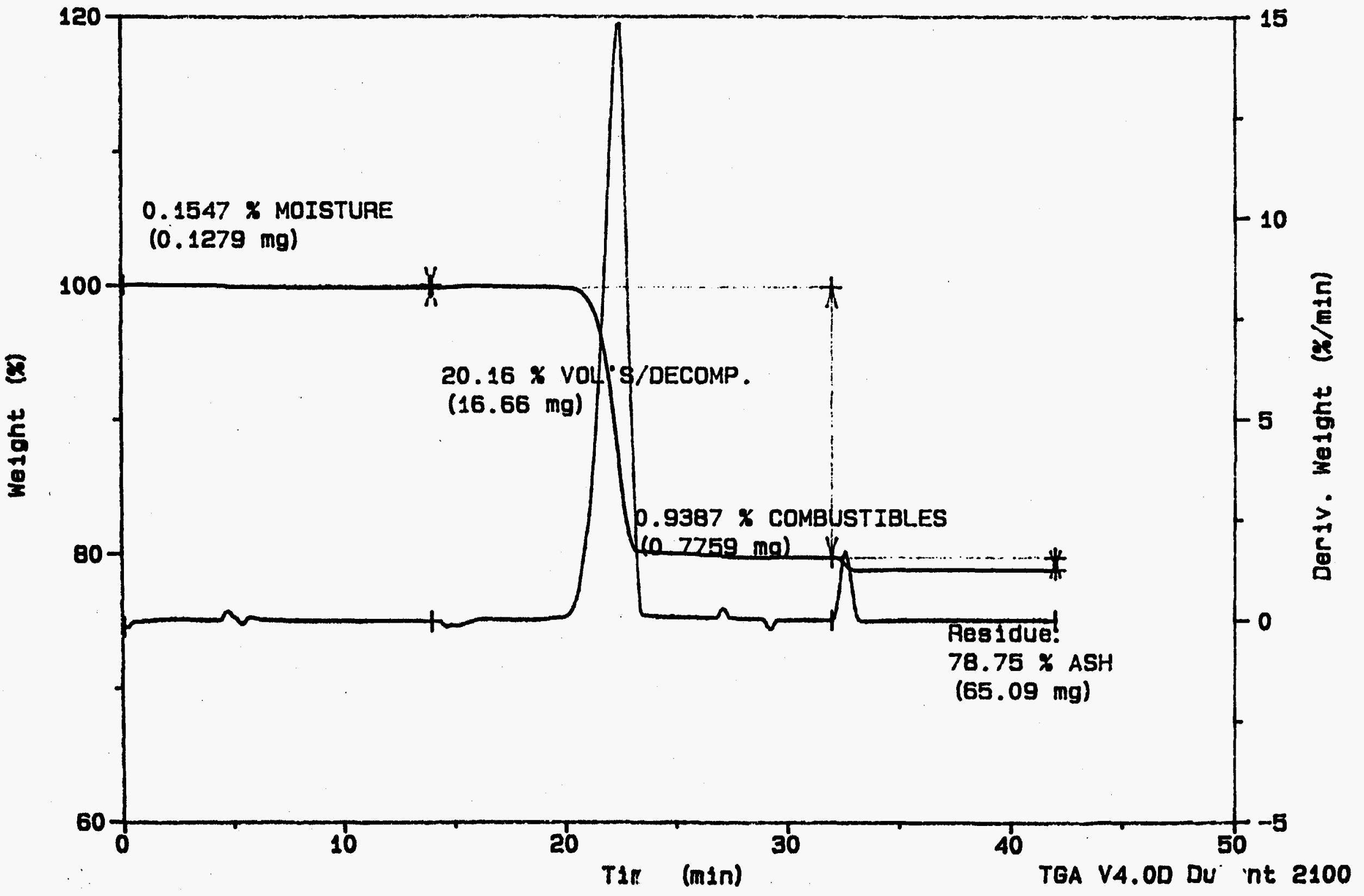

